\title{
THESIS
}

\section{IMPACT OF CHARRETTES AND THEIR CHARACTERISTICS ON ACHIEVED LEED CERTIFICATION}

\author{
Submitted by \\ Michael W. Knox \\ Department of Construction Management
}

In partial fulfillment of the requirements

For the Degree of Master of Science

Colorado State University

Fort Collins, Colorado

Spring 2013

Master's Committee:

Advisor: Caroline Clevenger

Brian Dunbar

Katharine Leigh 
Copyright by Michael W. Knox 2013

All Rights Reserved 


\section{ABSTRACT \\ IMPACT OF CHARRETTES AND THEIR CHARACTERISTICS ON ACHIEVED LEED CERTIFICATION}

Charrettes are collaborative, interdisciplinary workshops. They are a commonly used process in the design phases of sustainable building projects and are often used in Leadership in Energy and Environmental Design (LEED) certified building projects. Charrettes are implemented to increase collaboration and communication across different building professionals and stakeholders. However, it is unclear what specific outcomes of the charrette process are and what factors may contribute to the overall success of green building projects. The study seeks to answer what impact charrettes and their characteristics have on LEED certified building projects? It uses LEED points awarded as a metric.

Using a focus group, characteristics of charrette processes were identified. These characteristics were presented in a qualitative survey distributed to professionals involved with 177 projects certified using LEED for New Construction (NC) v2009. Looking broadly at the charrette process and its impact on the number of LEED points achieved revealed a significant positive relationship between LEED points and the implementation of charrettes. Correlation and regression analysis were used to examine the relationship of individual charrette characteristics to LEED points achieved. A significant negative correlation $(p<.05)$ was discovered between three separate characteristics which, in-turn, negatively impacted LEED points achieved.

Results suggest the charrette process has the potential to provide significant benefits regardless of characteristics implemented, but that to fully realize this benefit, the charrette 
should not include factors that limit a group's ability to produce creative ideas, goals, and solutions. 


\section{ACKNOWLEDGEMENTS}

I would like to express my deepest appreciation to my thesis advisor, Caroline Clevenger, who has had the patience to put up with me on an almost weekly basis answering my questions, revising this project, and keeping me on track to graduate- your guidance has been instrumental to the success of this project. I would also like to thank my committee members, Brian Dunbar for providing me the initial and continuous inspiration for green building and charrettes; and also Katharine Leigh, the in-depth feedback and revisions you provided helped strengthen this research project.

I would like to thank my friends, family and co-workers who have been there to bounce ideas off, help me with proof reading and to motivate me to finish this paper. I am especially indebted to my parents, Steve and Lisa for your continued support throughout my undergraduate and graduate studies; and to my brother, Kevin, who helped me collect contact information online- your ideas saved me a great deal of time, and brain cells. 


\section{TABLE OF CONTENTS}

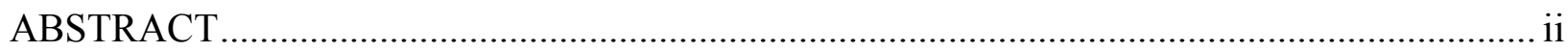

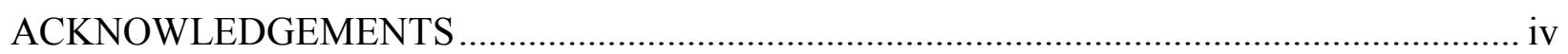

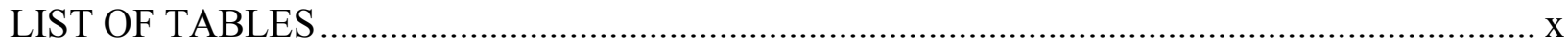

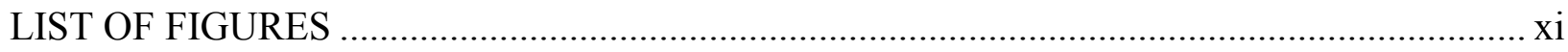

DEFINITION OF TERMS …...................................................................................

CHAPTER I INTRODUCTION ................................................................................. 1

Statement of Problem....................................................................................................... 2

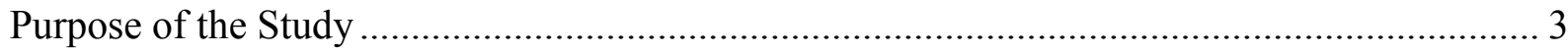

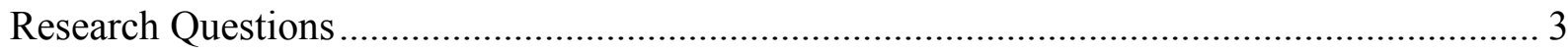

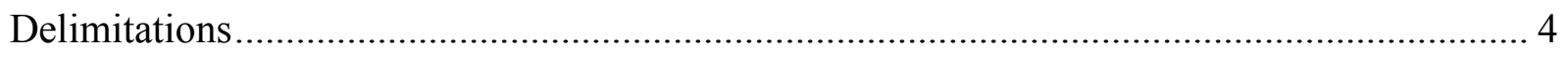

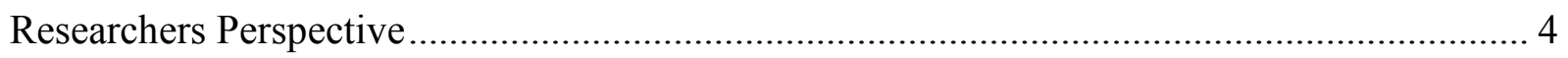

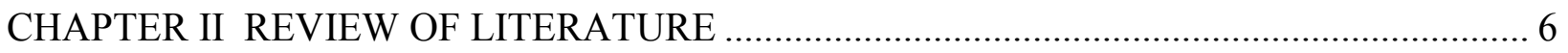

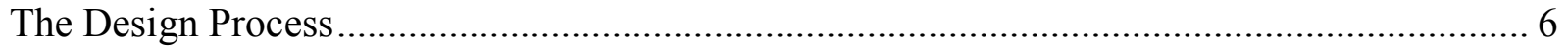

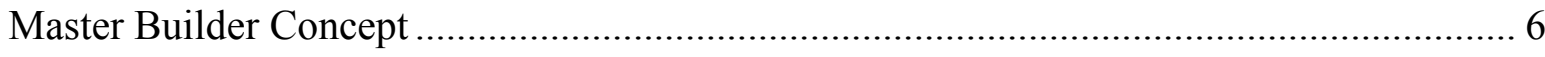

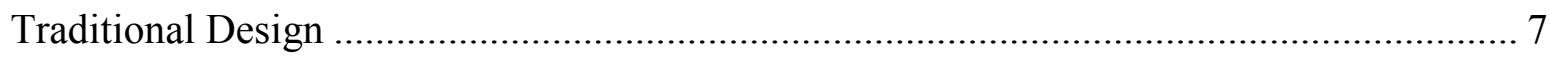

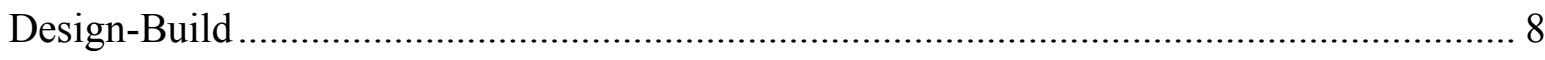

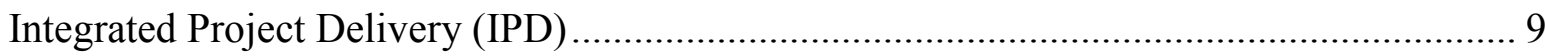

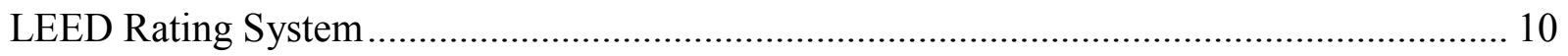

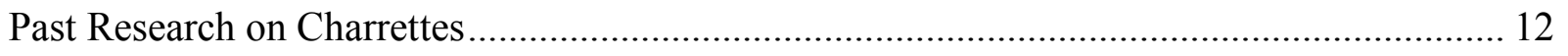


Environmental Design Charrette Workbook

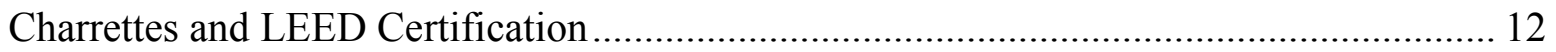

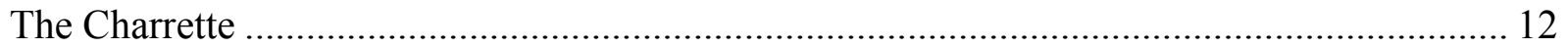

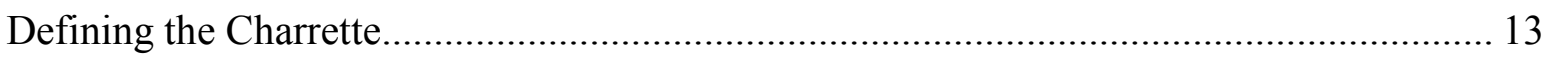

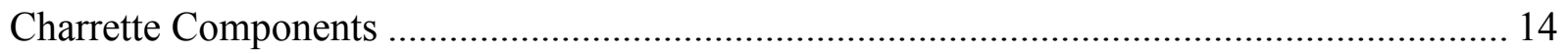

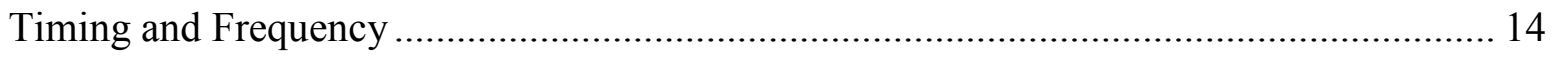

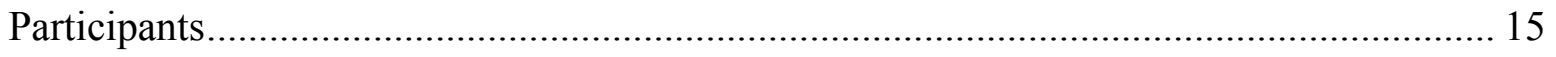

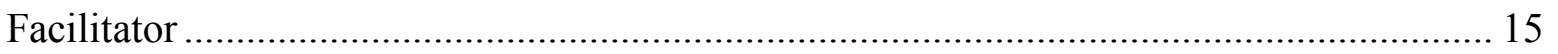

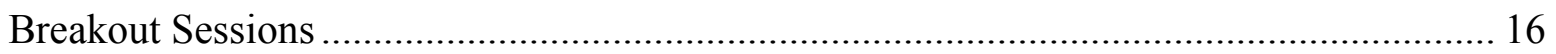

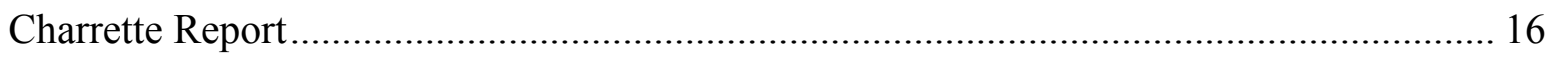

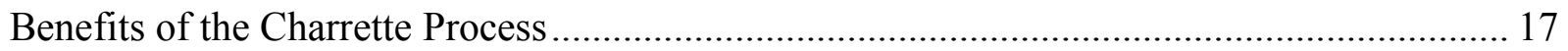

Increased Collaboration and Communication................................................................... 17

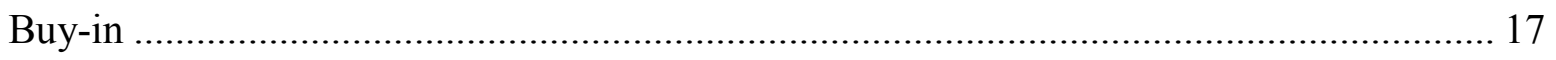

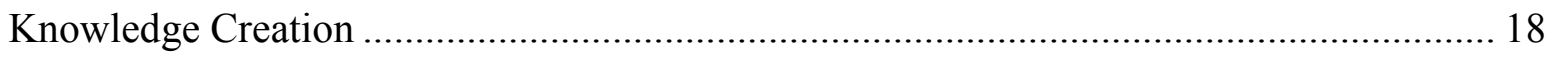

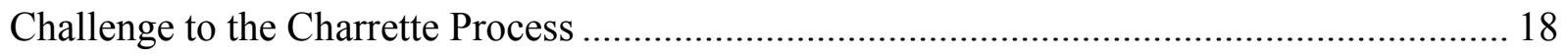

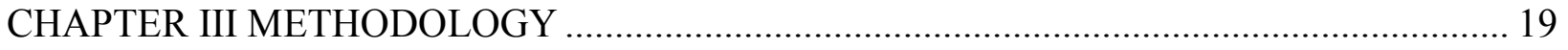

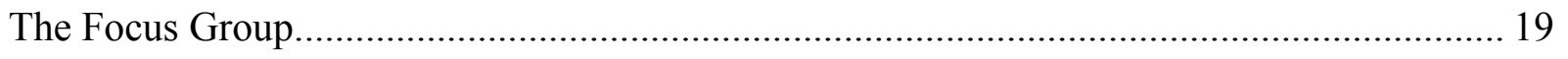

Sample

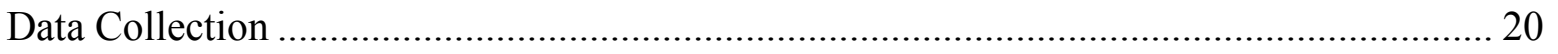

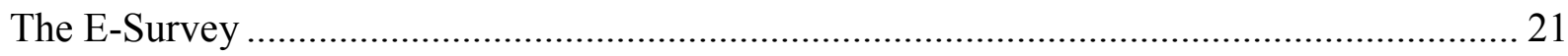


Quantitative Research Strategy.

Sample. 22

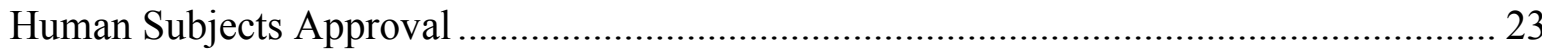

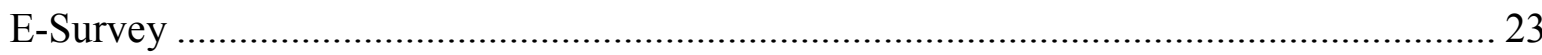

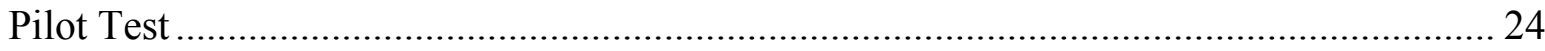

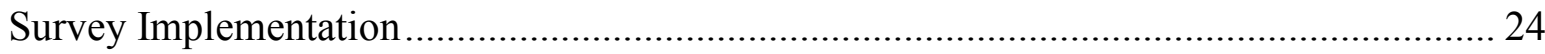

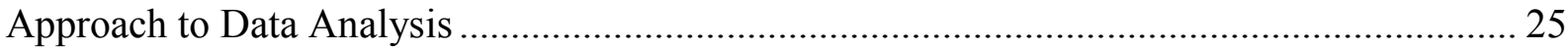

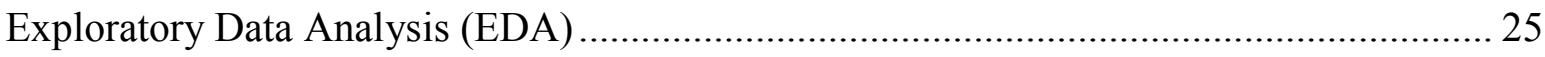

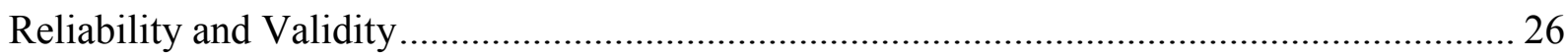

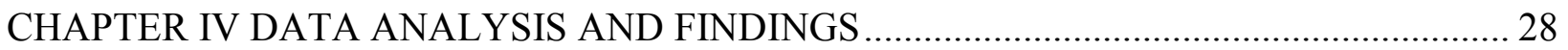

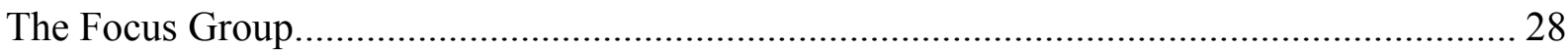

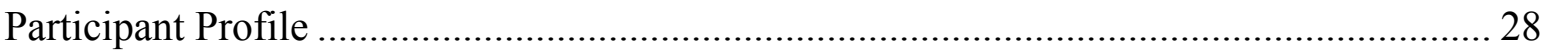

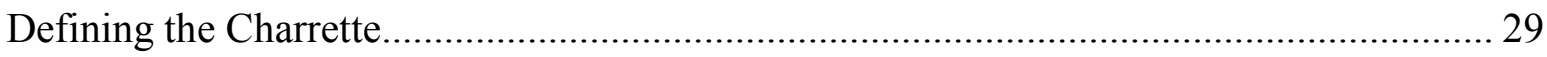

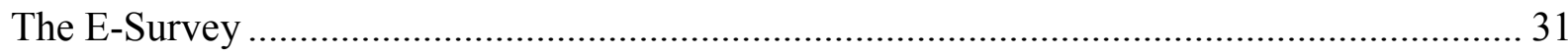

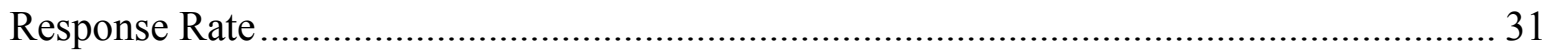

Building Project Profile ……………………………………………………………..... 31

Analysis of Non-Charrette Projects .................................................................................. 32

Analysis of the Charrette Projects................................................................................... 34

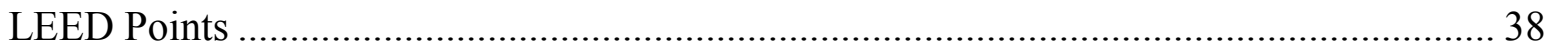

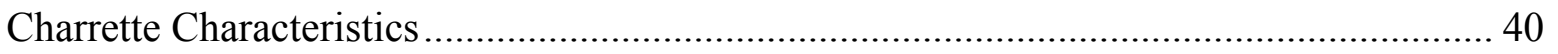


Charrette Follow-up Questions

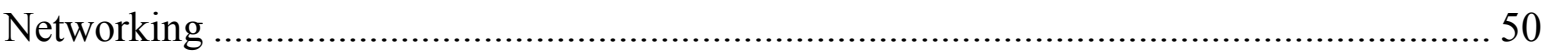

Open-ended Charrette Questions ................................................................................... 52

CHAPTER V DISCUSSION AND CONCLUSION …..................................................... 55

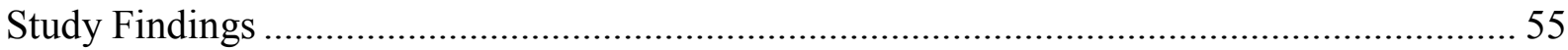

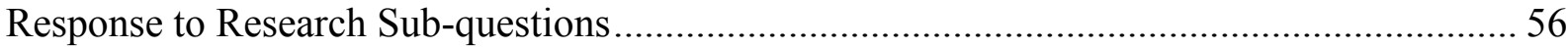

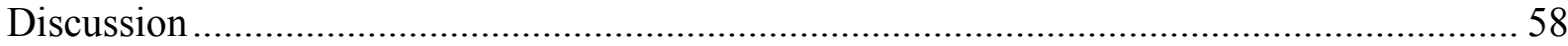

Conceptual Charrette Process Model ....................................................................................... 59

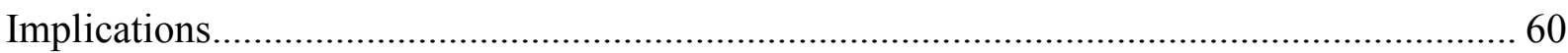

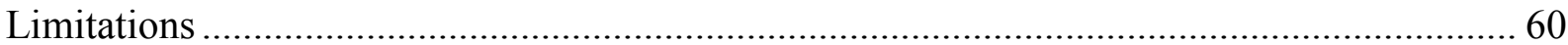

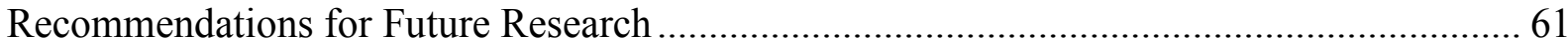

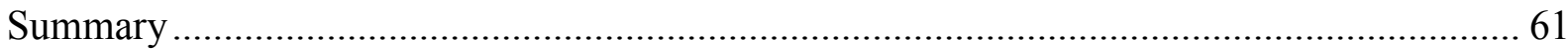

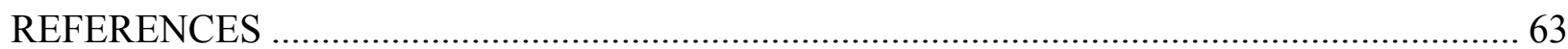

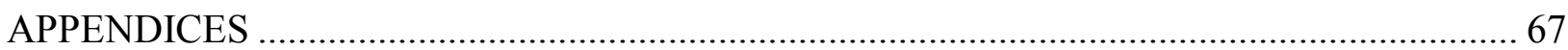

Appendix A: Focus Group Email Recruitment Script ................................................... 68

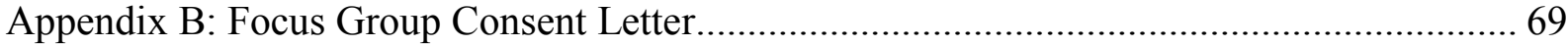

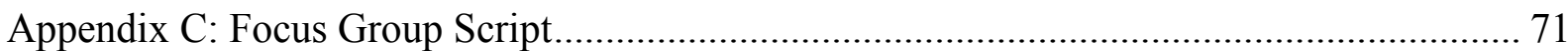

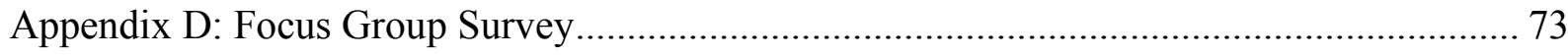

Appendix E: Initial Email Recruitment Script.............................................................. 74

Appendix F: E-Survey Email Recruitment Script .................................................... 75 
Appendix G: E-Survey Email Recruitment Script- First Reminder

Appendix H: E-Survey Email Recruitment Script- Final Reminder .................................. 77

Appendix I: E-Survey Questions \& Consent ...................................................................... 78

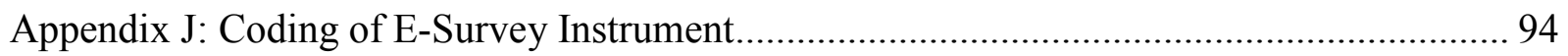

Appendix K: Quantitative E-Survey Responses .......................................................... 107

Appendix L: Qualitative E-Survey Responses .......................................................... 111

Appendix M: Institutional Review Board Approval Letter .............................................. 124

Appendix N: E-Survey Instrument Permission............................................................. 125 


\section{LIST OF TABLES}

Table 1. Relationship between Survey Items and Research Questions .................................. 24

Table 2. Charrette Characteristics Identified by Focus Group Participants.............................. 30

Table 3. Questions from Projects Not Implementing Charrettes ............................................ 33

Table 4. Intercorrelations, Means, and Standard Deviations for LEED Point Achievement

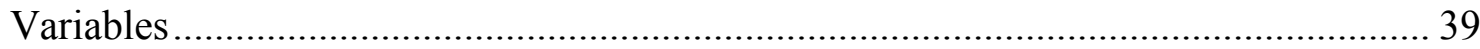

Table 5. Comparison of Charrettes Implemented and LEED Points Achieved......................... 40

Table 6. Intercorrelations, Means and Standard Deviations for LEED Points and Short Charrette

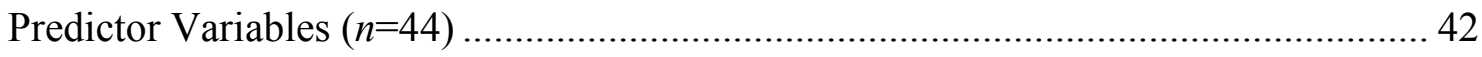

Table 7. Short Charrette Characteristic Predictors of LEED Points $(n=44) \ldots \ldots \ldots \ldots \ldots \ldots \ldots \ldots \ldots . . . . . . . . . . . . . . . . .43$

Table 8. Intercorrelations, Means and Standard Deviations for LEED Points and Long Charrette

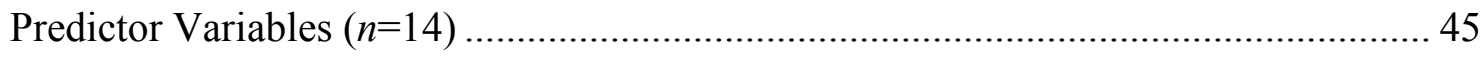

Table 9. Long Charrette Characteristic Predictors of LEED Points $(n=14)$............................ 46

Table 10. LEED Point Average Comparison....................................................................... 47

Table 11. Questions for Projects Implementing Charrettes ................................................. 49 


\section{LIST OF FIGURES}

Figure 1. Conceptual charrette process model (Knox, 2013) ............................................. 5

Figure 2. Response distribution by building project type ................................................. 32

Figure 3. Response distribution of charrettes by design phase ......................................... 36

Figure 4. Percent of charrette involvement by participant............................................... 37

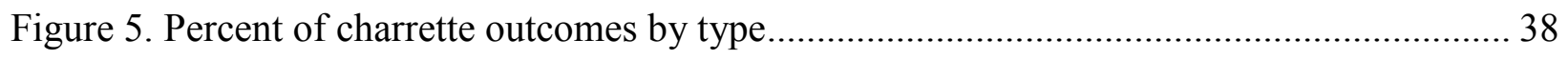

Figure 6. Percent of characteristics applied by Short Charrettes .......................................... 41

Figure 7. Percent of characteristics applied by Long Charrettes ......................................... 44

Figure 8. Comparison of common characteristics among charrette types .............................. 48

Figure 9. Building projects by networking category ….............................................. 51

Figure 10. Average LEED points per networking category ............................................ 52

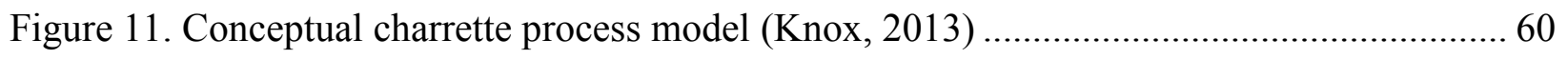




\section{DEFINITION OF TERMS}

The following terms and definitions are referenced in this research study:

Charrette: conceptualized as an intensively focused, interdisciplinary, collaborative work session during which participants identify problems and respond to the problem parameters by the design and development of solutions in consensus (Lennertz et al., 2006; Lindsey et al., 2009; Watson \& American Institute of Architects, 1996).

Integrated Project Delivery (IPD): "a project delivery approach that integrates people, systems, business structures and practices into a process that collaboratively harnesses the talents and insights of all participants to reduce waste and optimize efficiency through all phases of design, fabrication and construction" (AIA California Council, 2007).

Interdisciplinary: integrating different disciplines together such as architects, engineers, construction managers, owners, consultants and others (Kibert, 2008).

LEED: Leadership in Energy and Environmental Design, LEED is an internationally recognized green building rating system (U.S. Green Building Council, 2013c).

Long Charrette: a charrette lasting longer than four hours in length (Knox, 2013).

Short Charrette: a charrette lasting two hours or more and four hours or less in length (Knox, 2013).

Stakeholder: individuals and organizations reasonably affected by project outcomes (Lennertz et al., 2006).

USGBC: U.S. Green Building Council, a non-profit organization promoting green buildings and is best known for developing a series of green building rating systems (U.S. Green Building Council, 2013a). 


\section{CHAPTER I}

\section{INTRODUCTION}

Buildings are complex environmental entities, comprised of systems working in tandem to meet the needs of building occupants and their communities; these systems are often designed by a combination of architects, engineers, and other building consultants due to their complexity. When sustainable or green building objectives become the focus, the construction and operation of these built environments increases in complexity and level of challenge compared to traditional methods of design and construction (Pulaski, Horman, \& Riley, 2006; Robichaud \& Anantatmula, 2011; Rohracher, 2001). Furthermore, any change to building design can potentially impact mechanical systems, energy demands, facility management and occupant comfort making successful integrated design particularly challenging.

To successfully overcome additional complexities and challenges of green building projects, collaboration across design and building disciplines is essential (Robichaud \& Anantatmula, 2011). Fong (2003) discussed the importance of multidisciplinary teams in product design and facility design. Multidisciplinary teams not only increase, but are essential for knowledge creation and sharing among teams leading to more productive and improved team performance. One process commonly used to increase collaboration and communication across disciplines is the charrette- a gathering of building professionals and stakeholders to examine project elements. Charrettes employ the use of multidisciplinary teams to assist and enhance knowledge creation and sharing among participants by interacting and communicating with one another in identifying and solving problems (Fong, 2003). Fong's findings can be extended to suggest a positive correlation between the use of charrettes in the design phase to achieving a 
higher level of sustainability in the project as a whole. The U.S. Green Building Council (USGBC) recognized the importance of multidisciplinary teams focusing on the Integrated Project Delivery (IPD) system as a means of incorporating multidisciplinary views in the certification process. The upcoming version of the LEED rating system, LEED v4, awards points for using integrated processes (U.S. Green Building Council, 2013b).

Charrettes have been used to increase collaboration, shared vision, buy in, and investment among stakeholders and participants in the design and construction of a building project (Gibson \& Whittington, 2010). Varying forms of the charrette process may be used throughout the design and construction phase of a building project, as either problem-seeking or problem-solving activities. They are directed toward enhancing innovation and increasing collaboration and variations include brainstorming charrettes, strategy charrettes, design charrettes, implementation charrettes, environmental charrettes, project charrettes or other. For the purposes of this research, the word "charrette" is inclusive of all types of charrettes. The charrette is conceptualized as an intensively focused, interdisciplinary, collaborative work session during which participants identify problems and respond to the problem parameters by the design and development of solutions in consensus (Lennertz, Lutzenhiser, \& National Charrette, 2006; Lindsey, Todd, \& Hayter, 2009; Watson \& American Institute of Architects, 1996). The charrette process demonstrates greatest impact at early stages of the design process but can occur in any stage of design or construction (Robichaud \& Anantatmula, 2011).

\section{Statement of Problem}

Limited research findings exist documenting the impact of implementing the charrette process in the design of LEED certified building projects. One research investigation positively linked the use of charrettes to an increase in the level of LEED certification achieved (Pettit, 
2003). Since 2003, the green building industry has evolved to include new and expanded LEED rating systems with a greater number of projects utilizing the charrette process when seeking LEED certification. This research investigation seeks to confirm a positive correlation between implementing charrettes and achieving a higher level of LEED certification (i.e. LEED points) as identified by Pettit. Since the LEED rating system is widely accepted by industry, and on a global level with the introduction of individual rating system's Global Alternative Compliance Paths, it is a useful measure of sustainable performance of building projects (U.S. Green Building Council, 2011).

\section{Purpose of the Study}

To effectively assess the role of charrettes in achieving LEED points, it is necessary to properly characterize charrettes. Green building experts identified salient characteristics of charrettes in a pre-project focus group. This information helped to inform the research and create definitional parameters regarding specific factors/components of charrettes potentially beneficial to green building and LEED certification.

The purpose of this research study is to a) identify the relevant characteristics of charrettes in green building projects, and to b) examine the relationship between these characteristics and the extent to which charrettes may have an impact on LEED project certification. Underlying objectives of the research are to identify effective implementation of future charrettes.

\section{Research Questions}

The following questions shaped the study: RQ1: Are there important characteristics of charrettes related to LEED certification? RQ2: Is there a relationship between these characteristics and LEED project certification? 


\section{Delimitations}

The study is limited to building projects achieving LEED for New Construction (NC) certification under LEED 2009, between September 2011 and September 2012, with all building projects achieving one of the four levels of LEED certification. Building projects were located within the United States and were identified using the USGBC's online LEED project directory.

\section{Researchers Perspective}

Without encouraging collaboration from diverse individuals with different views, experience, and knowledge, it is challenging to achieve a high level of sustainability in building projects. As someone passionate about sustainable building, I undertook this research project with the belief that collaboration is an integral part of developing better, smarter buildings. Decisions, made without considering all who may be affected may not meet overall project objectives by failing to consider cross-disciplinary views held by professionals and stakeholders. My perspective is framed in the postpositivist worldview where "causes probably determine effects or outcomes," (Creswell, 2009, pp. 6-7).

The conceptual charrette process model in Figure 1 creates a visual representation of the charrette process including inputs and outputs. The charrette process consists of several important steps. First, an interdisciplinary team is formed consisting of individuals from different backgrounds. Second, the charrette takes place gathering diverse inputs influencing the outcome. Third, charrette participant benefits and outcomes of the charrette process encompass design processes, collaboration, communication, and green practices. Finally, the potential impacts of a charrette, charrette outcomes. 


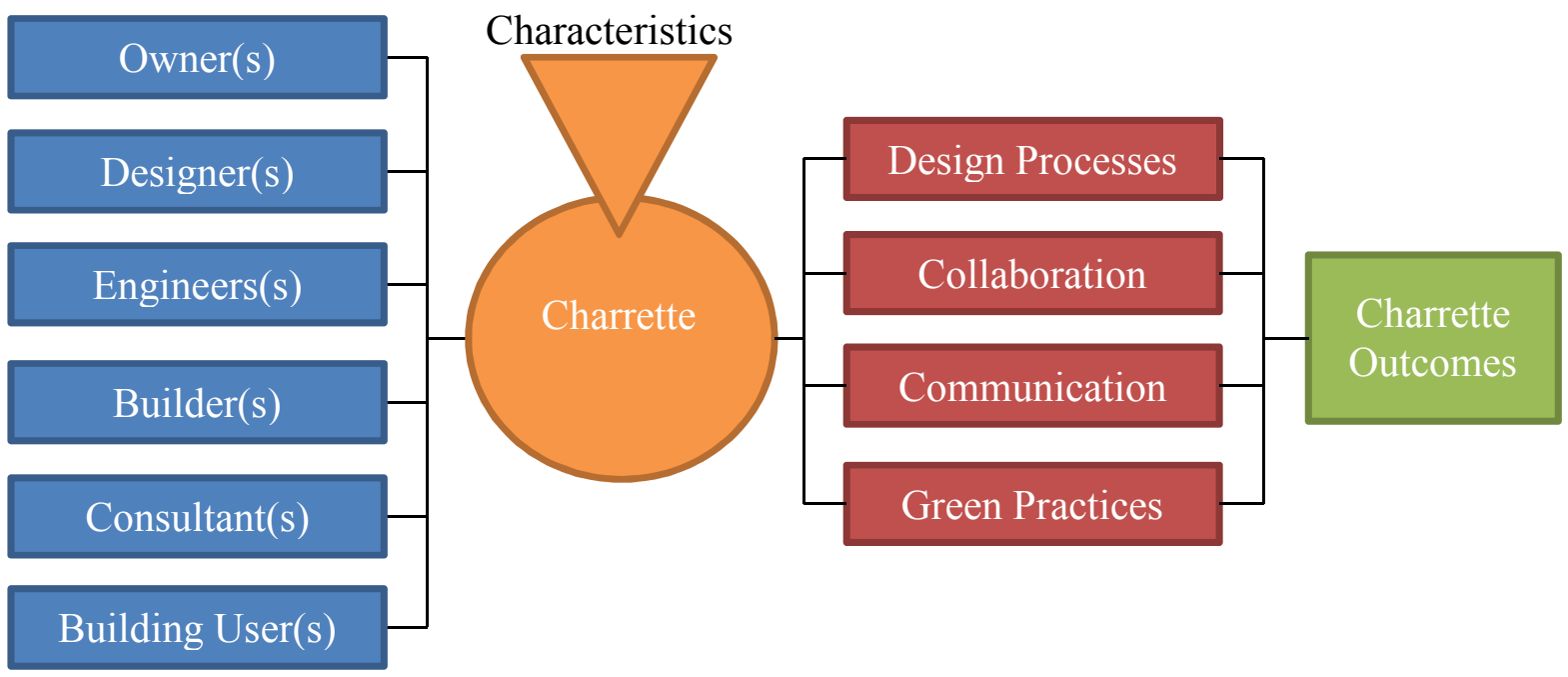

Figure 1. Conceptual charrette process model (Knox, 2013) 


\section{CHAPTER II}

\section{REVIEW OF LITERATURE}

The literature review covers three main areas: design process, LEED certification, and the charrette.

\section{The Design Process}

The design process incorporates a multi-step process going back to Walsas' (1926) initial design process model. Subsequent design models have identified additional steps, combined steps, and elaborated on this basic process, the gathering of client understanding and needs remains as the initial phase, in design language called programing. Architectural programing, related to the building structure, focuses on a "problem seeking" phase whereby required functions of a building are established (Pena \& Parshall, 2001); these functions may also encompass user behaviors. Problem seeking is directed at setting the building usage type, square footage, and goals of a project. Once these requirements are identified, an architectural program is used to develop the design of a building. The design process as a whole is the "problem solving" process, and is completed over different phases including: conceptual design, schematic design, design development, construction documentation, construction administration and postoccupancy evaluation. These distinct phases or steps differ in the amount of detail provided at every stage dependent upon the approach to construction.

\section{Master Builder Concept}

The original formal project delivery system in the United States was the master builder concept. Master builders were individuals who fulfilled all roles including designer, engineer, and builder. The master builder system of design and construction began to fragment into 
designer and constructor specialties in the late part of the nineteenth and early twentieth century with the master builder concept coming to an end with the arrival of new technologies (Konchar \& Sanvido, 1998). Such technologies required input from diverse individuals and specializations. The single person, or master builder, was no longer able to keep pace with these advances and thus several individuals with specialized knowledge were needed for project integrity and quality. Yates (2003) pointed out "construction industry fragmentation contributed to a reduction in the input of design professionals during construction, which in-turn has led to a reduction in their knowledge of construction" suggesting the need for integrating the design, engineering and construction disciplines to support improved design.

\section{Traditional Design}

The traditional design process, which stemmed from this movement toward specialization, has been used in a majority of existing building projects. Historically, viewed as a measure to lower the costs of the project delivery system, owners contracted with designers to create a design, and then separately with general contractors to construct the building, often using lowest bid price (Kibert, 2008).

In this scenario, the design itself goes through a series of handoffs prior to bid. After the owner selects the architect or designer, the design is passed to engineers and consultants who will take the "existing architectural and design decisions as constraints for generating design alternatives specific to their specialization" (Kanagaraj \& Mahalingam, 2011). A single point of contact is identified to manage the project, typically the architect, with remaining consultants or designers selected in chronological phases- with the contractor hired last after all other planning and design phases are completed (Robichaud \& Anantatmula, 2011). This sequential communication is attributed to the characterization of the traditional design process as linear and 
segregated where little or no collaboration exists or is created between key project participants during the design or even construction phases. Traditional design encourages the act of storing knowledge and information among a few individuals, creating a "silo effect" making it harder for project participants to build on or expand on the ideas of others (Robichaud \& Anantatmula, 2011; The American Institute of Architects, 2007). While a project is often delivered at a lower cost, the design may lack innovative design features or systems thinking with the use of processes that were not integral.

The traditional design process has been used on the majority of construction projects, however, research findings suggests that other, more integrated, design processes may offer better solutions for complex building projects such as green buildings (Kibert, 2008; Robichaud \& Anantatmula, 2011).

\section{Design-Build}

Design-build became a popular, alternative project delivery method, through which the contractor and architect/designer form a single entity in contracting with an owner. This method can reduce project cost, scheduling delays, risk and litigation actions compared to traditional building construction methods (Elvin, 2007). This method aligns with green building projects with a high degree of collaboration between design and construction phases (Kibert, 2008). However, the contractor actually serves as the coordinating entity, a fact that did not go unnoticed by the American Institute of Architects and thus creating an opportunity to examine the contractual relationships that cleared the way for an even greater integrated project delivery system to develop for larger, more complex projects. 


\section{Integrated Project Delivery (IPD)}

Integrated Project Delivery (IPD) and integrated design processes describe high levels of collaboration and teamwork in the design and construction of green buildings differing from the building method of design-build (Kibert, 2008). IPD encourages collaboration among a diverse range of project participants and stakeholders across an entire design and construction processes through and sometimes beyond occupancy. Participants may include owners, architects, engineers, consultants, builders, and building users. One way of encouraging collaboration and communication among these diverse parties is though interdisciplinary partnerships resulting from the use of charrettes (Reed \& et al, 2009). The ideas behind this design process engages systems as more powerful than individuals (Yudelson, 2009). The critical assumption is that not one person has all the knowledge and information to design a project, and every person who participates in the integrated design process contributes uniquely to the overall success of a building project. In the traditional design process, only the design team begins work during schematic design, but in the integrated design process, collaboration starts at the beginning of the project with all involved parties having input on design decisions and solutions (Kibert, 2008). This process benefits the project by solving problems earlier in the process, encouraging teamwork, innovation, and contributing to cost savings as well as building efficiencies.

The USGBC recognizes the importance of the integrated design process and even encourages the use of the integrated design process on buildings seeking LEED certification (Rossi, Brown, Park, \& Boser, 2009; The American Institute of Architects, 2007). The next update of the LEED rating system, LEED v4, develops a new credit category called Integrative Process (IP) and proposes to reward projects for using an integrative design process (U.S. Green Building Council, 2013b). 


\section{LEED Rating System}

Several green building rating systems exist, including the Living Building Challenge, Green Globes, and LEED (Leadership in Energy and Environmental Design) (Green Building Initiative, 2012; International Living Future Institute, 2010; U.S. Green Building Council, 2013c). This research acknowledges the LEED rating system as foundational in assessing the sustainability of a building project.

The LEED rating system was developed by the U.S. Green Building Council in 2000 to assess a buildings performance and impact on the surrounding environment. The rating system has evolved since its inception to include several distinct rating systems aimed at rating different types of buildings (New Construction, Existing Buildings, Commercial Interiors, Core \& Shell,

Schools, Retail, Healthcare, Homes, and Neighborhood Development) and with regional considerations. Each multi-attribute rating system addresses seven major categories - Sustainable Sites, Water Efficiency, Energy and Atmosphere, Materials and Resources, Indoor Environmental Quality, and Innovation and Regional Priority. Projects earn points by meeting the prerequisites and requirements within each category; more point's garners a higher rating awarded. Categories for points are submitted and reviewed through design and construction phases.

The number of buildings that earn green certifications have been on the rise, with numbers doubling every two years (Fuerst, 2009; Fuerst \& McAllister, 2011) suggesting that LEED and other certification programs are important and have a significant impact on the future of design and construction of building projects.

The LEED rating system continues to evolve and will soon update from LEED 2009 to the next rating system, LEED v4. This new rating system will update credits and add several new 
credit categories. Updates to the rating system are important because they allow the rating system to evolve with the ever-changing green building industry and in the case of LEED, for the community at large.

\section{The LEED Process}

Any project seeking LEED certification must first register the project with the GBCI (Green Building Certification Institute), the third party extension of the USGBC (Green Building Certification Institute, 2011). This organization is responsible for project certification and also professional credentialing. Project registration is typically performed prior to or during the design of the building. Tracking credits are accomplished by using LEED Online, with all documentation done electronically. The project's documentation is entered online where submittal of credits is completed, reviewed, and awarded. After a project has gone through the necessary design and construction phases the final review is executed and the project can be awarded a level of Certified, Silver, Gold or Platinum based on the number of LEED points achieved in the appropriate environment.

\section{LEED Benefits}

Research suggests LEED certification impacts energy consumption, human comfort, productivity, environmental impacts and also real-estate value (Fuerst, 2009; Newsham, Mancini, \& Birt, 2009). According to Newsham (2009), LEED certified buildings use, on average, $18-39 \%$ less energy per floor area than their conventional counterparts regardless of the certification level received. Research has shown LEED buildings impact building users in a positive way by increasing indoor environmental quality including incorporating natural light, views of the outside and reducing levels of VOC (volatile organic compounds). Fuerst (2011) finds reduced operation costs, productivity increases of workers, reduced turnover and 
absenteeism, and tax incentives are among some of the benefits LEED certified buildings project provide, often demanding rental price premiums of approximately $5 \%$ over non-certified buildings.

\section{Past Research on Charrettes}

\section{Environmental Design Charrette Workbook}

In 1996, the AIA (American Institute of Architects) published a report on the use of Environmental Design Charrettes. This report was based on a series of charrettes simultaneously held throughout the United States and focused on energy, building ecology, landscaping, waste prevention, resource reclamation, cultural issues, and regional scale planning (Watson \& American Institute of Architects, 1996). The report recaps lessons learned, and resources for conducting Environmental Design Charrettes. While the report was not conducted as a rigorous research project, it does provide a foundation for how to conduct and improve upon the charrette process.

\section{Charrettes and LEED Certification}

Preliminary research has been conducted on the charrette process and how it relates to the level of LEED certification achieved. An unpublished study, conducted in 2003, "Investigating the Relationship of Charrettes and LEED Certified Buildings" found a positive link between the use of charrettes in the design process and a higher level of LEED certification achieved as a result of implementing charrettes (Pettit, 2003). Pettit's study guides the context of this investigation.

\section{The Charrette}

Different stories exist for how the word charrette emerged from history. The word literally means small cart. During the nineteenth century in Paris, for example, students from 
l'Ecole des Beaux Arts would jump on a cart sent to collect their work, and would frantically attempt to put the finishing touches on their projects (The Fannie Mae Foundation, 2003). The definition of charrette has evolved into meaning an intense burst of ideas, creativity and design.

Charrettes are typically collaborative, interdisciplinary workshops aimed at providing design and planning guidance, but are distinguished from other types of workshops by their intense nature and holistic approach (Lennertz et al., 2006). They have been used in federal organizations such as the Federal Highway Administration, the U.S. Department of Energy, the U.S. Green Building Council, the U.S. Army of Engineers, and by members of the American Institute of Architects (Gibson \& Whittington, 2010). They can be used in any situation or industry wishing to incorporate design thinking within project parameters, but most commonly associated with urban planning, community, and building design processes. When used in the building design process, conducting a charrette is used to increase communication, ideas, and consensus among participants aiding in the conceptualization and delivery of building projects. Breakout sessions, where participants focus on a particular aspect of the design such as mechanical systems, material use, water or other aspects, may be used and then bring discussions back to a whole-building perspective (RSMeans, 2011).

\section{Defining the Charrette}

Today two definitions dominate the literature. "The Charrette Handbook" written by the National Charrette Institute (NCI) is focused primarily on community planning charrettes including lengthy charrettes integrated into the NCI's dynamic planning process (Lennertz et al., 2006). The process is complex and involves significant planning prior to a charrette taking place and consists of three phases: Research, Education, and Charrette Preparation; The Charrette; and 
Plan Implementation. The NCI charrette is characterized as a collaborative workshop that includes all stakeholders and lasts more than four consecutive days (Lennertz et al., 2006).

Another charrette handbook, "A Handbook for Planning and Conducting Charrettes for High-Performance Projects" by the National Renewable Energy Laboratory (NREL) was written to help users conduct charrettes during the design of high performance buildings (Lindsey et al., 2009). This handbook differs from NCI and defines the charrette as a collaborative, multiday session with the goal of creating realistic and achievable designs. Lindsey (2009) goes a step further to describe different types of charrettes. These charrettes are broken up between a Workshop Charrette, a Minicharrette, and Full-Scale Charrette with each differing in length and purpose. Lindsey's (2009) definitions are defined below:

- Workshop charrette- half day length, large-group presentations and discussions aimed at introducing participants to design concepts, strategies, and the charrette process

- Minicharrette- one to one-half day length, includes a workshop with interactive exercises aimed at encouraging buy-in, developing performance goals, and identifying appropriate strategies and technologies

- Full-scale charrette- two or more day length, includes a workshop with intensive breakout group discussions aimed at encouraging buy-in, developing performance goals, identifying appropriate strategies, technologies, and developing sketches (pp. 6-7)

\section{Charrette Components}

The following components are identified in the literature as fundamental distinctions with regard to charrette characterizations.

\section{Timing and Frequency}

Timing relates to when a charrette occurs in the design process. Robichaud (2011) points out if design professionals and other members of the project team are involved from the start of a project, the charrette process has the highest potential to increase sustainable practices at 
minimal cost. While charrettes may result in the greatest impact early in the design process, they may occur in any stage.

One of the largest reasons for incorporating design charrettes early into the design process is to increase opportunity for cost savings, in schedule and operational characteristics, as well as design solutions, done by improving the definition of project scope (Gibson \& Gebken, 2003). There are different ideas as to optimal length and format of a charrettes, but most studies suggest a one to two day workshop where participants meet off and on with breaks for an eighthour day. In the case of the Environmental Design Charrette, the workshop might last longer, over a two to three day period (Watson \& American Institute of Architects, 1996). The length of a charrette depends on project and workshop goals. Charrettes may also be implemented at multiple times throughout the design process. In the case of a project utilizing IPD, charrettes may be used between every stage of design (Reed \& et al, 2009).

\section{Participants}

Since a defining characteristic of the charrette process is collaboration among diverse people, a critical component of charrettes is the participants themselves. There is no set list of who should participate in a charrette, and participants may differ depending upon the project type and scope. Some of the most common participants include owners, project sponsors, engineers, architects, designers, technical representatives, user representatives, key stakeholders, general contractor or construction manager, and charrette facilitators (Gibson \& Gebken, 2003; Gibson \& Whittington, 2010).

\section{Facilitator}

The facilitator is an integral aspect of a successful charrette. Lindsey (2009) states an entire charrette significantly depends upon the facilitators ability to motivate participants, by 
keeping the charrette activities focused and on track. Whether there are a few participants or several dozen, the facilitator is responsible for guiding the charrette process and keeping everyone on task. The facilitator should be an expert in group dynamics and have a good idea of scope definition; their job is to promote consensus decisions among the group and to resolve any conflicts that may occur during the process (Gibson \& Gebken, 2003). The facilitator must avoid making decisions or offering his/her opinions to the group, but should act as an unbiased observer (Edward Gibson Jr \& Gebken II, 2003). The facilitator doesn't necessarily need to be an expert on the topics discussed in the charrette; their role is to be a good leader (Watson \& American Institute of Architects, 1996).

\section{Breakout Sessions}

In large charrettes, it can be difficult to encourage participation from all participants; in order to encourage participation from all participants, smaller breakout or workshop sessions commonly occur (Lindsey et al., 2009). Both the NCI and NREL handbooks recommend the use of breakout sessions or small workshops during the charrette process. Discussions, exercises, and design activities are typically the subjects of these breakout groups.

\section{Charrette Report}

A charrette report is usually produced following a charrette. The report is used to summarize the information discussed, and outcomes which can then be sent to all stakeholders and participants (Lindsey et al., 2009). The NCI recommends a debriefing meeting in the days following a charrette insuring that everyone is on the right track and helping to keep feedback loops intact (Lennertz et al., 2006). 


\section{Benefits of the Charrette Process}

There are many documented benefits to using a charrette. The following are the most cited benefits in the literature:

- Increased collaboration

- Buy-in

- Knowledge creation

\section{Increased Collaboration and Communication}

The charrette is naturally a collaborative process. It brings many people together who would not otherwise engage with one another. The main benefits from charrettes have been identified as: kicking off the design process, providing a forum for those that can influence a project in a big way, encouraging agreements, saving time, money, and promoting enthusiasm (Lindsey et al., 2009). When charrettes are used in the pre-design phases, participants can have a large influence on the final outcome of the building.

Another benefit to using charrettes is the increased communication that occurs between all parties. Robichaud (2011) explains in conventional construction, project architects, engineers, and builders deliver services in technical isolation creating the "silo effect." This "silo effect" makes it hard to manage change, mitigate risks, and contain costs because of the lack of communication. Incorporating a charrette at the beginning of a project will likely improve communication and an exchange of ideas among project stakeholders (Robichaud \& Anantatmula, 2011).

\section{Buy-in}

In many cases, charrettes can encourage buy-in from participants, by allowing the participants to have an influence over a project they are more likely to "buy-in" to the project 
(Gibson \& Whittington, 2010). Lennertz (2006) states that when people are involved in the design process, they will support the results of the project. This can be helpful for those that initially block or don't support a project in the beginning.

\section{Knowledge Creation}

The collaborative nature of charrettes creates ideas and new knowledge of the project. Fong (2003) states that the collaborative nature of multidisciplinary teams are important to produce new knowledge. Knowledge creation presents an opportunity for shared learning and can lead to a change in people's perceptions and positions potentially avoiding costly rework (Lennertz et al., 2006). It is essential to a projects success.

\section{Challenge to the Charrette Process}

\section{Cost}

Costs to conduct a charrette vary widely. Building owners, private developers, public agencies or non-governmental agencies typically sponsor a charrette while funding is provided by single entities, groups of funders, grants or other sources. Lennertz (2006) states that charrettes implementing a dynamic planning process, as outlined in the NCI charrette handbook, can expect the process to cost anywhere from $\$ 75,000$ to $\$ 500,000$ depending on the size, technical specialties, and final products. The U.S. DOE Federal Energy Management program indicates that charrette costs are usually between $\$ 25,000$ to $\$ 40,000$ dollars (RSMeans, 2011). While the cost may be a challenge, an integrated design ultimately saves money by cutting down energy, operational costs, expensive repairs and reduce tenant turnover over the lifetime of a building (Lindsey et al., 2009). It is also possible to reduce the cost by using professional volunteers, local agencies, and university architecture and planning departments (Lennertz et al., 2006). 


\section{CHAPTER III}

\section{METHODOLOGY}

While past research suggests charrettes are beneficial to the design of building projects, no published research has been conducted specifically on charrettes as it relates to the success of green building projects. In addition, research has been limited in articulating which characteristics of charrettes contribute to the overall success of green building projects. To fill this gap, the research design used a two phase process to collect data that were both qualitative and quantitative.

Responses were collected from professionals in a focus group and an e-survey. Phase I comprised a focus group of practitioners engaged in green building activities, and Phase II, an online e-survey. The goal of the focus group was to identify critical charrette characteristics. The goal of the e-survey was to document to what extent these characteristics were present on real projects achieving LEED certification. The e-survey was distributed to all LEED v2009 certified projects in the United States in an attempt to gather information from individuals with first-hand knowledge about whether and how the charrette process was applied on the projects. This section describes the study's methodology including population, sample, instrumentation, instrumentation development and procedures for collecting and analyzing survey data. The main method of data collection was an e-survey. Questions on the survey were informed by a focus group prior to the survey's distribution.

\section{The Focus Group}

To better understand what characteristics experts believe were the most influential on project outcomes; a focus group was conducted to identify and define charrette characteristics. A 
focus group discussion is a popular method used to support the development of surveys; it allows the researchers to ask open-ended questions to a group of individuals prior to asking more directed questions in a survey. The purpose of a focus group discussion is to gather a range of different views around a research topic and to gain a better understanding of that research topic from the focus group participants (Hennink, 2007). It allows people in the study's population to discuss their perceptions, experiences, and feelings to what could and will be measured in the study (Fowler, 2009).

A quantitative research strategy was chosen to answer research question two: "Is there a relationship between these characteristics and LEED project certification?" Quantitative research is a method of examining relationships among variables, and is most often associated with survey research or experimental research where numerical data is collected and therefore mathematical and statistical calculations can be used (Creswell, 2009).

\section{Sample}

Researchers recruited nine focus group participants. Participants were recruited by email (Appendix A) and were all part of the Fort Collins, Colorado green building community with professional experience with charrettes during the design of sustainably constructed building projects. An exit survey was used at the end of the focus group to document the experience level of participants (Appendix D).

\section{Data Collection}

The focus group met for approximately ninety minutes; the researcher posed several open-ended questions to the group related to their experience with design charrettes (Appendix C). The researcher led the focus group while discussions were hand-recorded by two faculty members acting as scribes. The main purpose of the focus group was to a) contribute to a 
definition of the charrette from a practitioner perspective, and b) to discuss various characteristics present during the charrette process for two charrette typologies characterized as "short" and "long" charrettes, and subsequently to identify which characteristics potentially had the most significant impacts when designing LEED certified buildings (i.e., resulting in a greater number of LEED points awarded).

The researcher analyzed these expert opinions regarding charrette characteristics immediately following the focus group discussion. Initially, a comparison of recorded responses was made between each scribes' notes to ensure applicable information was accurately captured. Notes were used to refine the charrette characteristics and create a master list of characteristics for each charrette type. The master list of characteristics was narrowed down to the most significant characteristics as expressed by the participants when designing a LEED certified buildings. External review by an expert in green building practices, present at the focus group, validated a final list of characteristics.

\section{The E-Survey}

\section{Quantitative Research Strategy}

Data from a large percent of the study's population were necessary to perform an accurate statistical analysis. In order to collect a large amount of responses from the population, an e-survey was chosen for data collection. Using an e-survey allowed researchers to gather data from a larger percent of the population in a shorter time while allowing the sample to be representative of the entire population. E-surveys also allowed survey participants to remain anonymous throughout distribution and collection of surveys. Use of an e-survey was an appropriate choice for a study seeking to collect perceptual information about charrette characteristics from a potentially large number of participants (Orcher, 2005, p. 36) and from a 
postpositivist perspective, to collect empirical observational data to verify and build on ideas about the impact of charrettes (Creswell, 2009, pp. 6-7).

\section{Sample}

The study's population is building projects achieving LEED for New Construction (NC) certification under version 2009 (LEED-NC v2009) between September 2011 and September 2012 located within the United States. The USGBC lists LEED certified projects in a publically available, online project directory and, as of September 2012, there were 639 projects having achieved at least the lowest level of certification and fit the description of the study's population.

Due to the USGBC's privacy policy, specific contact information for LEED certified projects was not publicly available. However, project names, locations and LEED points achieved were available in the USGBC's LEED Project Directory. Contact information was sought out for each project in the study's population. Contact information included email addresses and names of individuals who were familiar with the design phase of the building project in question and were identified as being able to accurately respond to a survey.

Web searches were conducted for each project in the population to find contact information of project representatives who worked on these specific LEED building projects. An email was sent to each initial contact found online who appeared to be associated with the building project in question (Appendix E). The email specifically asked which individual involved in the project would be best suited to respond to the study's survey. Identified individuals were typically the project architect, engineer or other design team professional. One hundred and sixty-nine projects were classified as "Confidential" in the USGBC's LEED Project Directory and were ineligible for the study due to missing project information. One hundred and seventy-seven building projects were found to have a project representative responsive to the 
initial email request; these 177 building projects make up the study's sample size $(n=177)$. The sampling method used was a non-probability convenience sample with participants selected based on response to the initial email invitation.

\section{Human Subjects Approval}

The protocol for this study was reviewed by the Research Integrity and Compliance Review Office's Institutional Review Board (IRB) at Colorado State University and determined to be in compliance with NIH CFR 46 and the federal regulations governing review of research involving human subjects (Appendix M).

\section{E-Survey}

A cross-sectional survey, released at one point in time was sent to all building projects sampled (Appendix I). Questions asked about the level of LEED certification achieved (LEED points), types of charrettes conducted, number of charrettes conducted, and characteristics of charrettes present during the charrette process. Characteristics listed were a result from the initial focus group conducted in Phase I. Question logic was used to automatically direct participants to certain applicable parts of the survey based on whether a charrette was conducted or not. For instance, if a project did not use a charrette, the participant would not be asked about charrettes during the survey. Table 1 details how the survey questions relate to the research questions. The survey included a mix of quantitative and qualitative questions. Questions 6, 8, 9, 11, 12, 13, 14, 15, 16, 17 were adopted from Pettit's survey instrument (Pettit, 2003). Permission was granted from the author to use the survey instrument in this study (Appendix N). 
Table 1

Relationship between Survey Items and Research Questions

\begin{tabular}{ccccc}
\hline $\begin{array}{c}\text { Research } \\
\text { Question \# }\end{array}$ & Concept & $\begin{array}{c}\text { Related } \\
\text { Questionnaire } \\
\text { Item(s) }\end{array}$ & $\begin{array}{c}\text { Level of } \\
\text { Measurement }\end{array}$ & Statistical Test \\
\hline 1 & $\begin{array}{c}\text { Charrette } \\
\text { Characteristics } \\
\text { Charrette }\end{array}$ & Focus Group & $\mathrm{n} / \mathrm{a}$ & $\mathrm{n} / \mathrm{a}$ \\
2 & $\begin{array}{c}\text { Characteristics \& } \\
\text { Outcomes }\end{array}$ & $3,14,19$ & Nominal & $\begin{array}{c}\text { Multiple Regression, } \\
\text { Man-Whitney U, } \\
\text { Means, Percentages }\end{array}$ \\
\hline
\end{tabular}

\section{Pilot Test}

The survey was pilot tested with approximately 30 college undergraduate and graduate students studying green building practices. Each participant received the recruitment email (Appendix F) and reminder email (Appendix G \& Appendix H). Open-ended feedback was requested to locate components or elements that might present themselves as difficult or confusing. Minor changes to the instrument included word changes and grammatical fixes.

\section{Survey Implementation}

An e-survey engine was used to collect the data and distribute the email invitations using a database set up by the researcher. Data were categorized by project contacts, email addresses, and the project name. Although the researcher had contact information of each project, responses were not linked to this identifying information to retain anonymity.

Each of the 177 LEED project contacts initially received a recruitment email (Appendix F) describing the purpose of the study, how information would be collected, and researcher contact information. Recruitment emails also noted no personal information would be collected from the participant if they chose to participate. Because some participants may have actually worked on more than one LEED certified project, a custom tag was used to inform the email 
recipient of the specific project to eliminate the chance of answering the survey about a project that did not meet the study qualifications; a survey link directed the participants to the survey. After reading the consent form, respondents were asked to click a button acknowledging willingness to participate in the study.

Participants were provided with a 30 day window to complete the survey. At one-week and three-week intervals, reminder emails were sent to each potential participant (Appendix G \& Appendix H). In addition to the reminder emails, an incentive to take the survey was included in all email communication to potentially increase the number of respondents. Following completion of the survey, respondents were redirected to a separate survey to enter their name into a random drawing to win a $\$ 50$ Amazon gift card.

\section{Approach to Data Analysis}

\section{Exploratory Data Analysis (EDA)}

The data included nominal, ordinal, and scale data inviting examination of the descriptive statistics to examine means, shape of the distribution (skewness), range of data to gain an understanding of central tendency, variability, range of scores, and whether the variables were normally distributed.

Correlations and multiple regression modeling were carried out to subsequently examine association of variables showing the relationships between one dependent variable and one or more independent variables. Due to the exploratory nature of the research project, the stepwise method of multiple regression was best suited for the research because no previous research of this type had been done previously to predict what characteristics would be most significant. Multiple regression was used to examine the number of LEED points achieved with the independent variables encompassing charrette characteristics. The study sought to examine 
which, if any, characteristics were more likely to increase or decrease the amount of LEED points achieved for a project; SPSSv.20 (Statistical Package for the Social Sciences) was used to analyze the data (IBM Corporation, 2011).

\section{Reliability and Validity}

The use of focus groups and e-surveys as research instruments in standard research practices are considered reliable as a means of data collection (Fowler, 2009; Stewart, Rook, \& Shamdasani, 2006). Findings from the focus group, in terms of characteristics and definitional items, were reviewed by an expert in green building design and construction (see Table 1, correlation between items and the research questions).

Each e-survey item was evaluated for relevance to the research questions and the survey instrument was reviewed by two experienced researchers prior to release to clarify and stream line the e-survey for methodology objectives and content comprehension. Several revisions were made to the e-survey to increase understanding and ease of response. Custom tags used in email recruitment scripts ensure survey respondents were alerted about responding about the correct project.

The validity of the research is assumed to be high. Specifically, using LEED points as a measure of charrette outcome (positive or negative impact on the level of sustainability achieved by the project) is particularly appropriate and has concurrent validity for a population of LEED certified building projects. The building industry in general, and many public and private organizations, including the Federal government, has adopted LEED certification as a key indicator of the level sustainability for a project. 
The reliability of the research is also assumed to be stable and acceptable since the research implements traditional research methods in a similar fashion to a previous unpublished research (Pettit, 2003) and presents similar findings. 


\section{CHAPTER IV}

\section{DATA ANALYSIS AND FINDINGS}

Data was collected in two phases. In Phase I, a focus group was conducted with practitioners having exposure to project charrettes in their professional work to a) articulate descriptive characteristics of charrette types used during the process of building projects and, b) the characteristics of short and long charrettes as defined in this research to examine similarities and differences among characteristics. Characteristics were separated into two groups based upon the charrette length, (Short and Long charrettes) as defined by focus group participants.

In Phase II, data was collected using an e-survey distributed to a non-random sample of LEED project representatives. Questions were based upon the charrette characteristics identified by participants and with subsequent expert review.

\section{The Focus Group}

\section{Participant Profile}

Participants completed a profile to allow the researcher to characterize participant practice experience by using a short survey (Appendix D). The mean value of participants' $(n=9)$ involvement with charrettes and green building was 13 years, having participated, on average, in approximately 28 charrettes. The professional role played in past charrettes varied including charrette facilitator, project owner, consultant, architect, engineer, and building user. Participants were asked to rate their experience level with the charrette process with $56 \%$ rating themselves as "Experienced" and 44\% as "Very Experienced" on a 4-point Likert-like scale (No Experience=1) suggesting expert levels of experience with the charrette process during the design of sustainably constructed buildings or projects. 


\section{Defining the Charrette}

Early in the discussions, charrette was defined and separated by the group into two categories; a "Short Charrette" and a "Long Charrette." These two types will be characterized from this point onward to differentiate from other types of charrettes. The Short Charrette was described as being two hours or more and four hours or less in length. The Long Charrette was described as being more than four hours in length.

The charrette process was separated into two groups based on length of time and considered the time commitments of participating professionals. The shorter length of time made for easier scheduling, categorized as the Short charrette, allowed charrettes to take place in morning or afternoon sessions. Long Charrettes would need more time commitment from participants and increased coordination due to scheduling longer sessions. Long Charrettes could span from one day to several days in length; participants frequently described the Long Charrette as more than four hours in length. Both types of charrettes did not align with the definition presented in the NCI charrette handbook (Lennertz et al., 2006). However, NREL handbook's Workshop Charrette, defines a similar length of time to the Short Charrette, with the Mini Charrette similar in length to the Long Charrette (Lindsey et al., 2009).

Characteristics were then collected for each type of charrette by asking "what characteristics of charrettes do you find the most important when designing for LEED certified buildings?" Characteristics were then ranked by frequency and importance by focus group participants for each charrette type. Table 2 shows the results of the focus group; common characteristics between both charrette types are denoted with an asterisk. 
Table 2

Charrette Characteristics Identified by Focus Group Participants $(n=9)$

\begin{tabular}{|c|c|c|}
\hline$\#$ & Short Charrette ( $\geq 2$ to $\leq 4$ Hours) & Long Charrette ( $>4$ Hours) \\
\hline 1 & $\begin{array}{l}\text { *Project goals defined before the charrette } \\
\text { takes place }\end{array}$ & $\begin{array}{l}\text { *Project goals defined before the charrette } \\
\text { takes place }\end{array}$ \\
\hline 2 & $\begin{array}{l}\text { *Interdisciplinary or specialty participants } \\
\text { were used }\end{array}$ & $\begin{array}{l}\text { * Interdisciplinary or specialty participants } \\
\text { were used }\end{array}$ \\
\hline 3 & *Defined/structured agenda & * Defined/structured agenda \\
\hline 4 & *Brainstorming & * Brainstorming \\
\hline 5 & *Part of a series of charrettes & * Part of a series of charrettes \\
\hline 6 & *LEED strategy/LEED checklist meeting & *LEED strategy/LEED checklist meeting \\
\hline 7 & *Held as a "Kickoff" for the building project & *Held as a "Kickoff" for the building project \\
\hline 8 & $\begin{array}{l}\text { Focused on one or more specific aspects of } \\
\text { the building project }\end{array}$ & $\begin{array}{l}\text { Educate the participants about the building } \\
\text { project }\end{array}$ \\
\hline 9 & Included few participants ( $<10$ people) & Addressed high level problems/challenges \\
\hline 10 & Targeted audience of participants used & $\begin{array}{c}\text { Rotating breakout group sessions are used } \\
\text { during the charrette }\end{array}$ \\
\hline 11 & & $\begin{array}{c}\text { Stakeholders participate as necessary } \\
\text { throughout charrettes }\end{array}$ \\
\hline 12 & & $\begin{array}{l}\text { Provides valuable time to communicate with } \\
\text { owners or owner representatives }\end{array}$ \\
\hline 13 & & $\begin{array}{l}\text { Produced high level innovation, } \\
\text { development, creativity and inspiration }\end{array}$ \\
\hline
\end{tabular}

\footnotetext{
Note. *Denotes common characteristics identified among respondents. Fourteen characteristics were found in common: project goals defined before the charrette takes place, interdisciplinary or specialty participants were used, defined/structured agenda, brainstorming, part of a series of charrettes, LEED strategy/LEED checklist meeting, Held as a "Kickoff" for the building project.
} 


\section{The E-Survey}

Analysis of responses collected from the e-survey is presented in the following sections.

\section{Response Rate}

Phase II analysis was conducted on data collected from an e-survey distributed to LEED project representatives. One hundred seventy-seven e-surveys were sent to project representatives, 72 surveys were returned. Response rate, including incomplete surveys, was $41 \%$ of total surveys sent. Sixty-six fully complete and useable e-surveys were returned and used for data analysis. Incomplete e-surveys were omitted from the data analysis.

\section{Building Project Profile}

The LEED certification levels of the building projects surveyed $(n=66)$ included the full range of certification levels: Certified level represented $16.7 \%(n=11)$, Silver level $28.8 \%$ $(n=19)$, Gold level 39.4\% $(n=26)$, and Platinum level 15.2\% $(n=10)$ of all responses. The mean number of LEED points achieved across projects was 60.35 and ranged from a minimum of 40 points to a maximum of 95 points.

Survey respondents were asked to identify the building project type(s) for the projects from a list of options. Figure 2 summarizes the distribution of building projects by type. The building types most commonly identified, in order, were Commercial Office, Other, Government, Higher Education and Industrial totaling over $75 \%$ of projects surveyed. Building types collected but not available as an option were included in the category "Other." This category included project types such as Golf Clubhouse Facility, Maintenance Building, Cultural Space, Auto Dealership, Neighborhood Development, Child Daycare and Lab School, Casino, Fire Station, Energy Innovation Center, Utility Operations Center, and Public Visitor Center. 


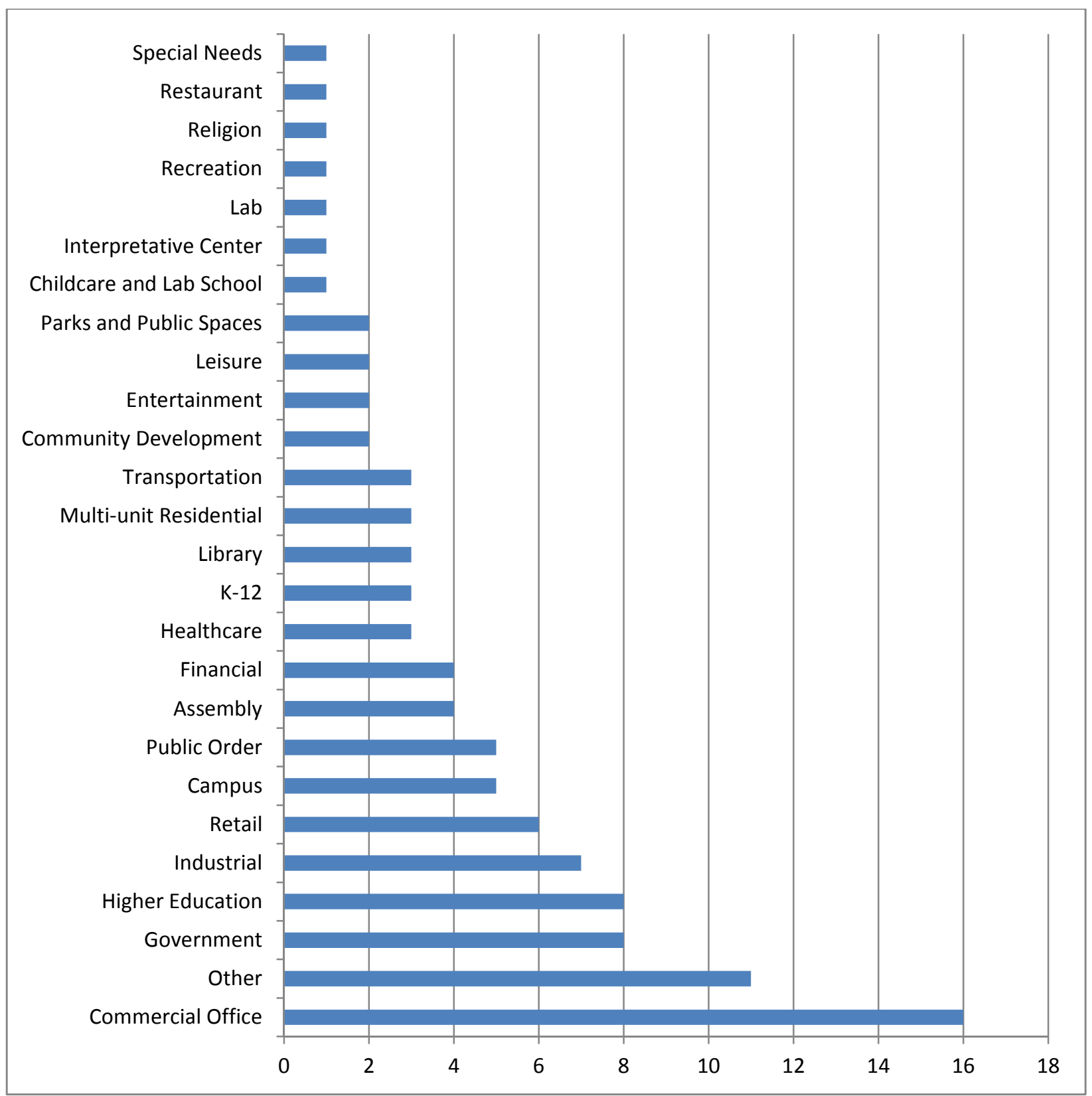

Figure 2. Response distribution by building project type

\section{Analysis of Non-Charrette Projects}

Of the 66 building projects analyzed, 20 projects (30\%) did not conduct any charrettes during the design process. Survey respondents of these projects completed a separate section of 
the questionnaire to find out about the design process and to understand why charrettes were not conducted.

Most building projects where charrettes were not conducted used the traditional design process, accounting for $85 \%(n=17)$ of projects. The remaining $15 \%(n=3)$ of projects were identified as using an integrated process such as Integrated Project Delivery (IPD).

Respondents of projects where charrettes were not performed and who identified their building project as using a traditional design process were asked if more LEED points were achieved because a traditional design process was used. Additionally, they were asked if using a charrette could have increased the number of LEED points achieved. Table 3 summarizes responses; questions were answered using a Likert scale ("Strongly Agree"=1; "Strongly Disagree $=5 ")$. The majority of responses indicated that the traditional design process was not a factor in achieving more LEED points. Responses were mixed when asked if more LEED points could have been achieved if a charrette was used. The responses indicate that the charrette process neither negatively or positively impacted the level of LEED certification achieved.

Table 3

Questions from Projects Not Implementing Charrettes

\begin{tabular}{|c|c|c|c|c|c|}
\hline Question & $\begin{array}{c}\text { Strongly } \\
\text { Agree }\end{array}$ & Agree & $\begin{array}{l}\text { Neither } \\
\text { Agree or } \\
\text { Disagree }\end{array}$ & Disagree & $\begin{array}{l}\text { Strongly } \\
\text { Disagree }\end{array}$ \\
\hline $\begin{array}{l}\text { 1. More LEED points were } \\
\text { achieved because a traditional } \\
\text { design process was used } \\
(n=16) \text {. }\end{array}$ & $0 \%(n=0)$ & $0 \%(n=0)$ & $\begin{array}{c}50 \% \\
(n=8)\end{array}$ & $\begin{array}{c}37.5 \% \\
(n=6)\end{array}$ & $\begin{array}{l}12.5 \% \\
(n=2)\end{array}$ \\
\hline $\begin{array}{l}\text { 2. More LEED point would } \\
\text { have been achieved if a } \\
\text { design charrette was used } \\
(n=17) \text {. }\end{array}$ & $\begin{array}{l}5.8 \% \\
(n=1)\end{array}$ & $\begin{array}{c}23.5 \% \\
(n=4)\end{array}$ & $\begin{array}{c}29.4 \% \\
(n=5)\end{array}$ & $\begin{array}{c}23.5 \% \\
(n=4)\end{array}$ & $\begin{array}{c}17.6 \% \\
(n=3)\end{array}$ \\
\hline
\end{tabular}


Questions relating to projects that implemented an integrated design process, but did not implement charrettes are not summarized in this section because a low number of responses $(n=3)$ were collected. Actual responses are shown in Appendix L.

Open-ended questions were also posed to all respondents whose projects did not implement any charrettes to understand why design charrettes were not conducted as part of the design process, 16 respondents answered this question. An analysis was conducted by coding and categorizing the responses into themes. Summaries of the analysis are below:

1. In your opinion, why was a design charrette not conducted as part of the design process for the building project in question?

The most commonly stated reason as to why charrettes were not used was because the design was mostly complete due to the building project being based upon past projects, or prototype buildings where the design elements were already complete. Some stated there was not a need for additional design input. Scheduling constraints were also an issue; this was due to accelerated project schedule or not having enough time to conduct a charrette during design. Additionally, some cited project owners who did not advocate for an integrated design process. Owners, in some cases were not educated about the charrette process or the LEED rating system. Finally, some firms indicated that they do not actively practice any sort of integrated design process and were not open or comfortable in utilizing charrettes for the project in question.

\section{Analysis of the Charrette Projects}

Of the 66 building projects surveyed, $70 \%$ of building projects $(n=46)$ implemented at least one charrette during the design process and $30 \%$ of projects $(n=20)$ did not implement any charrettes. A Short Charrette, as defined previously, is a charrette lasting between two or more hours and four or less hours in length. Of all building projects surveyed, $68.2 \%(n=45)$ 
implemented at least one Short Charrette. A Long Charrette, as defined earlier, is a charrette lasting more than four hours in length. Of all building projects surveyed, $21.2 \%(n=14)$ implemented at least one Long Charrette.

\section{Frequency of Charrettes}

Respondents were asked to specify the number of charrettes that were conducted during the design process and at which phase of design they occurred. Building projects implementing at least one charrette $(n=46)$ implemented, on average, five Short and Long charrettes throughout all stages of design. Charrettes occurred during Conceptual Design 27\% $(n=63)$ of the time, Schematic Design 35\% ( $n=82)$ of the time, Design Development 24\% $(n=56)$ of the time, and Construction Document 14\% $(n=35)$.

Figure 3 shows the aggregate number of charrettes conducted by design phase category. In the case of the Short Charrette, the total number of charrettes peaked during the schematic design phase and steadily declined as the design process approached the construction document phase. As for the Long Charrettes, the largest total number of charrettes occurred during the conceptual design stage and also steadily declined as the design process approached the construction document phase. 


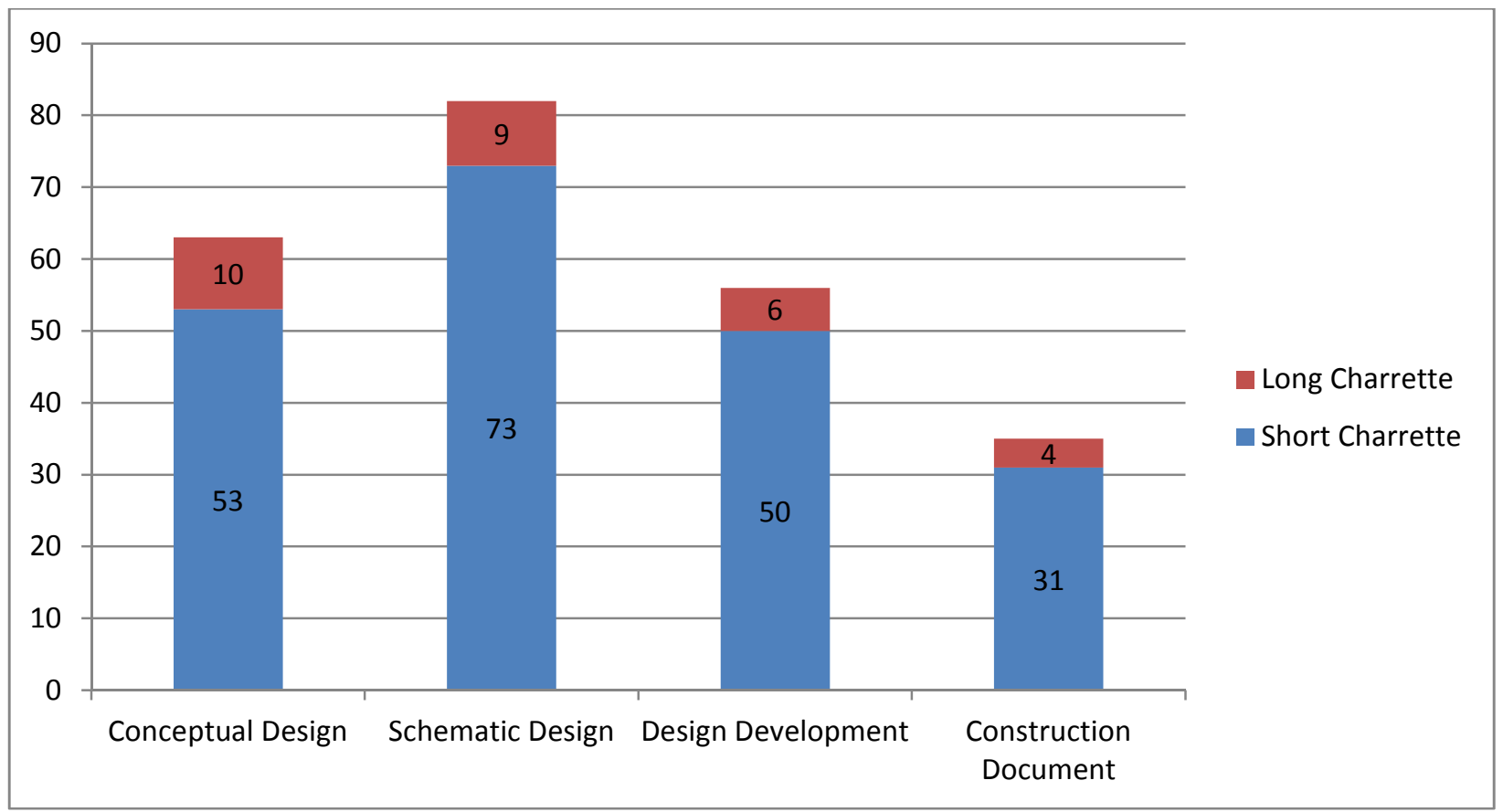

Figure 3. Response distribution of charrettes by design phase

\section{Charrette Participants}

Survey respondents were asked to identify individuals who were typically involved in Short Charrettes and Long Charrettes. Figure 4 shows percentages of charrette participants typically involved separated by charrette type. Architects were identified as being present for $100 \%$ of charrettes for both charrette types. Engineers and project owners were also present more than $80 \%$ of the time. Figure 4 also shows Long Charrettes having an equal or higher percentage of participants than that of Short Charrettes in all groups except commissioning agents. Respondents also indicated groups of participants that were not listed in the survey, their responses were recorded in the category "Other." They included GSA Representatives, Club Operators, and Photovoltaic System Designers. 


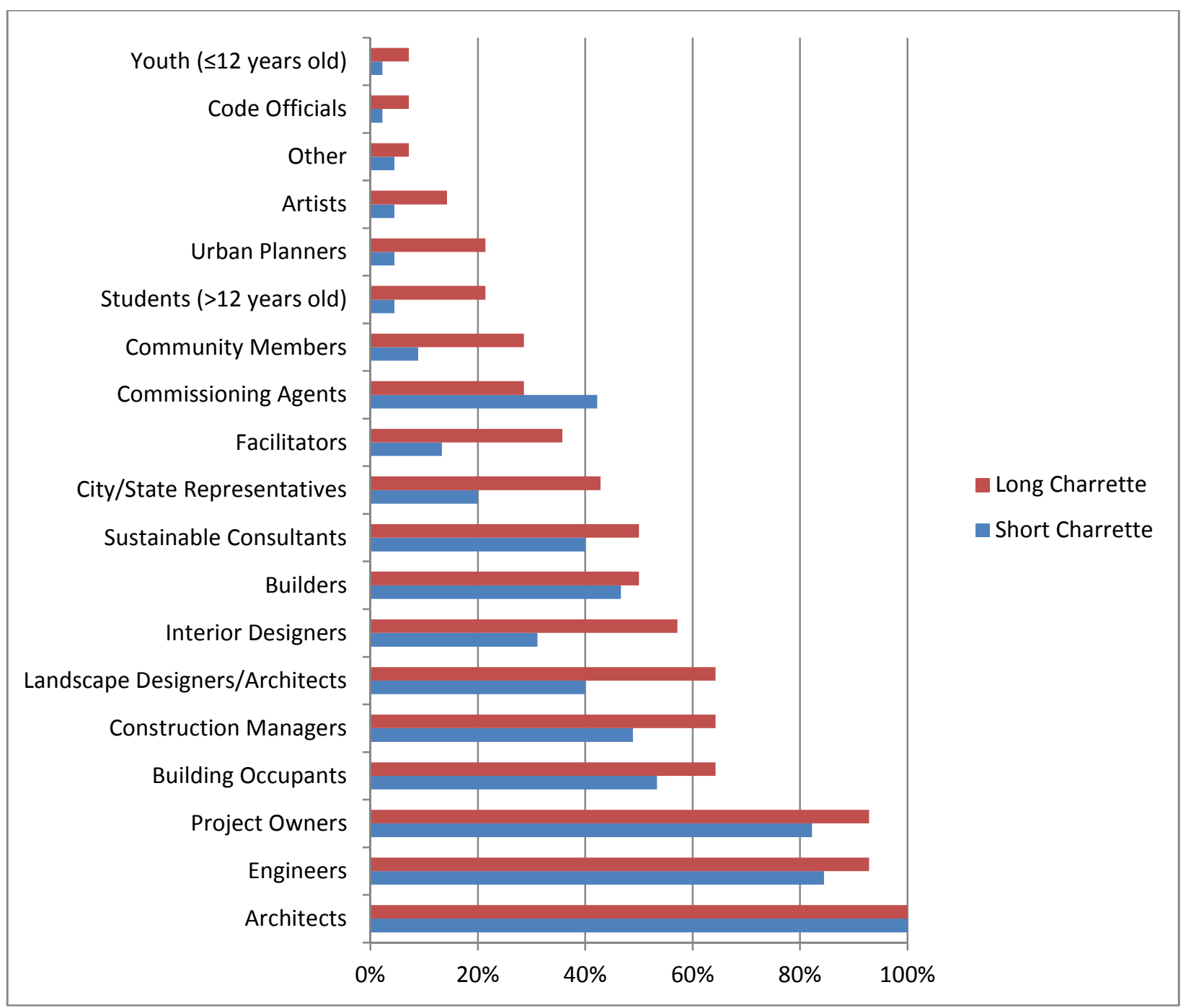

Figure 4. Percent of charrette involvement by participant

\section{Charrette Outcomes}

Respondents were asked to select from a list of typical charrette outcomes for both Short Charrettes and Long Charrettes. Outcomes listed included: Conceptual Design Documents, Schematic Design Documents, Design Development Documents, Construction Documents, LEED Checklist, Specific Design Decisions, Understanding of Project Desires, Establishment of Project Goals, List of Project Possibilities and Other. Figure 5 shows the percentage of projects having those outcomes. LEED Checklist was one of the most widely selected for outcomes of 
both types of charrettes, over $80 \%$. Understanding of Project Desires, List of Project Possibilities, Specific Design Decisions, and Establishment of Project Goals were all common outcomes of the charrette process.

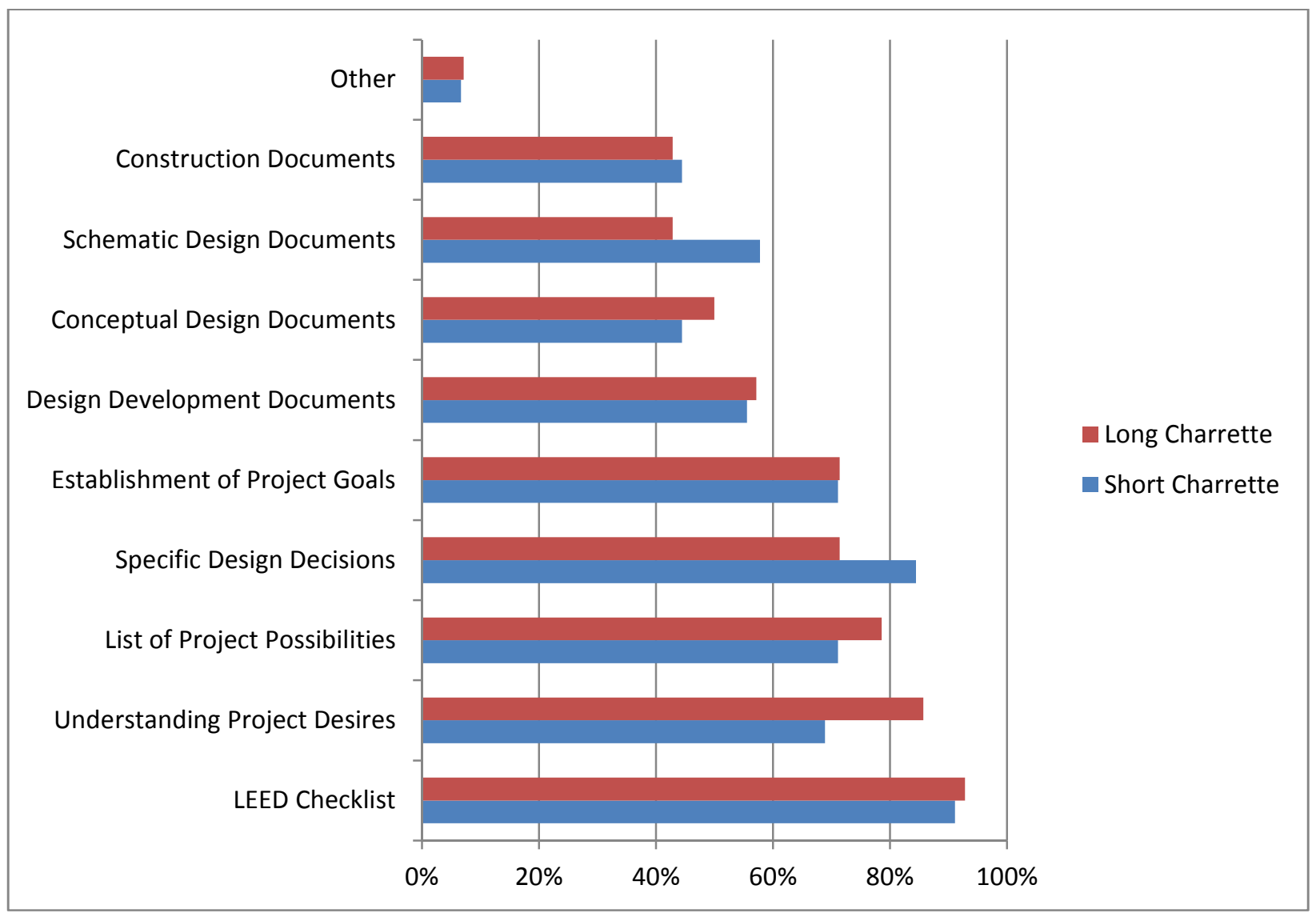

Figure 5. Percent of charrette outcomes by type

\section{LEED Points}

Several statistical tests were used to understand the relationship between the number of LEED points achieved and the implementation of charrettes. Out of the 46 building projects implementing charrettes, 45 of those projects used Short Charrettes with an average of 4.6 Short Charrettes conducted throughout the project and 14 projects using Long Charrettes with an 
average of 1.2 Long Charrettes conducted throughout the project. The total number of projects that used charrettes across both groups conducted an average of 5.1 charrettes. To test if there was a significant association between the number of charrettes implemented and LEED points, a correlation was computed. The number of charrettes implemented in each group was skewed, which violated the assumption of normality. Thus, the Spearman rho statistic was calculated and can be found in Table 4. No positive correlations were found to be significant between the number of charrettes conducted and a higher number of LEED points achieved. This means that implementing more charrettes during the design process was not a factor in achieving more LEED points.

Table 4

Intercorrelations, Means, and Standard Deviations for LEED Point Achievement Variables

\begin{tabular}{lcccccc}
\hline \multicolumn{1}{c}{ Variable } & 1 & 2 & 3 & 4 & $M$ & $S D$ \\
\hline 1. LEED Points & - & .25 & .11 & .19 & 60.35 & 13.12 \\
2. Total Short Charrettes & - & - & $.72^{* *}$ & $.96^{* *}$ & 4.60 & 4.41 \\
3. Total Long Charrettes & - & - & - & $.64^{*}$ & 2.07 & 1.21 \\
4. Total of Short and Long Charrettes & - & - & - & - & 5.13 & 4.96 \\
\hline
\end{tabular}
Note. $* p<.05 * * *<.01$

On average, LEED points for building projects implementing a charrette is 62.5 while projects not implementing any charrettes is 55.4, a difference of 7.1 points. A Man-Whitney $U$ test was conducted to evaluate whether there was a significant difference in LEED points achieved and building projects implementing at least one charrette compared to projects not implementing any charrettes. The results of the test can be found in Table 5 . The building projects that implemented either a Short or Long Charrette have significantly higher LEED point 
mean ranks (36.62) than building projects that did not implement any charrettes during design (26.33), $U=316.5, p=.045, r=-0.25$.

Table 5

Comparison of Charrettes Implemented and LEED Points Achieved

\begin{tabular}{cccccc}
\hline Variable & $N$ & Mean Rank & Sum of Rank & $U$ & $p$ \\
\hline Charrette Implemented & & & & 316.50 & $.045^{*}$ \\
Yes & 46 & 36.62 & 1684.5 & & \\
No & 20 & 26.33 & 526.5 & \\
Total & 66 & & & \\
\hline
\end{tabular}

Note. ${ }^{*} p<.05 \quad{ }^{* *} p<.01$

\section{Charrette Characteristics}

\section{Short Charrette Analysis}

Survey respondents whose projects conducted at least one Short Charrette $(n=45)$ during the design process were asked to select all characteristics that were typical of the Short Charrettes ( $\geq 2$ and $\leq 4$ hours) conducted for the building project in question. Characteristics listed were developed from the results of the focus group previously held. Figure 6 shows the percent of characteristics typically applied to Short Charrettes conducted. A majority of characteristics were applied to the Short Charrette. 


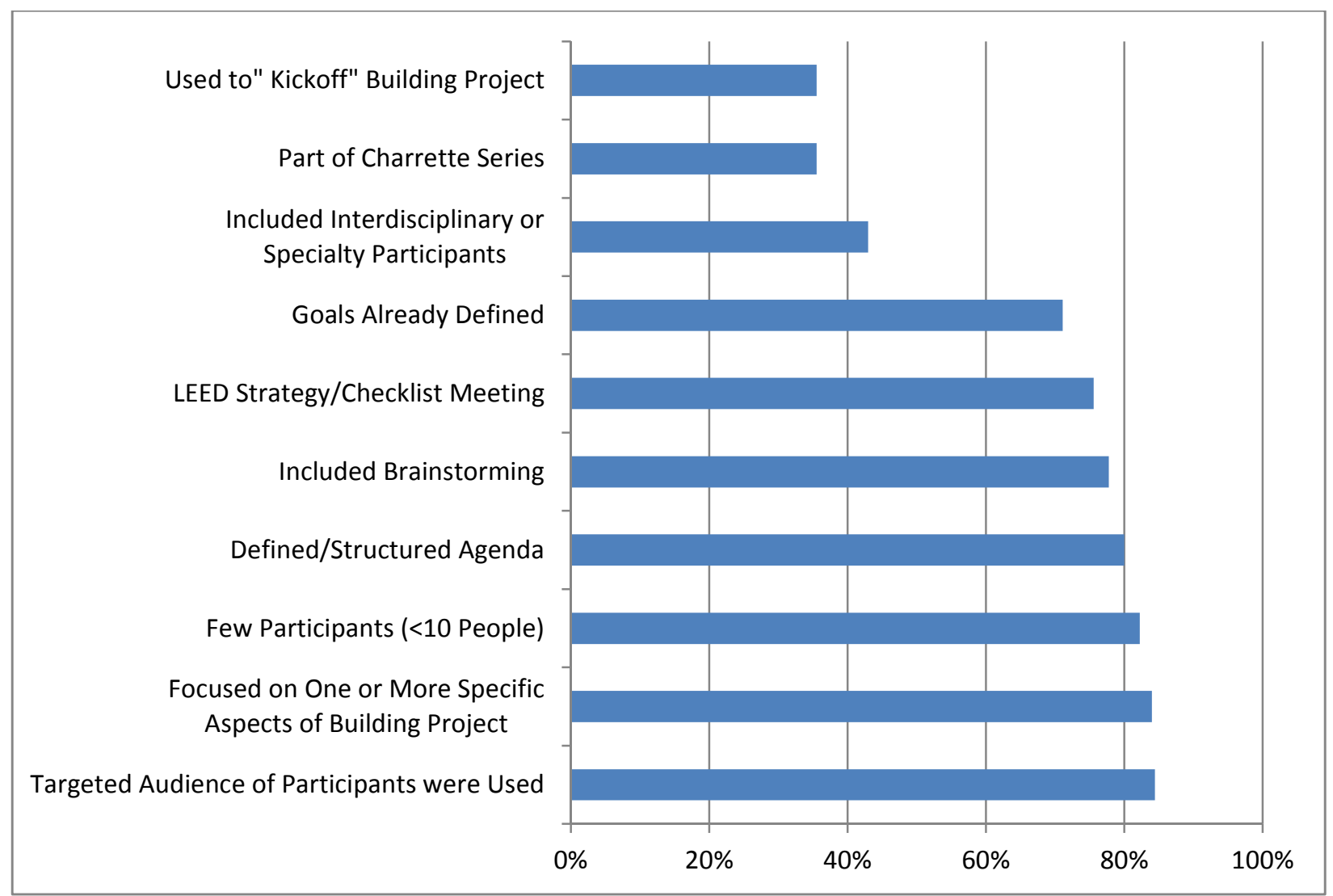

Figure 6. Percent of characteristics applied by Short Charrettes

Due to the exploratory nature of the research, the stepwise multiple regression method was used to investigate the best predictors of LEED points for Short Charrettes. The means, standard deviations and intercorrelations of LEED points and Short Charrette predictor variables (characteristics) can be found in Table 6. The best combination of variables, Model 2 located in Table 7, to predict LEED points were charrettes "Held as a LEED strategy/checklist meeting" and charrettes having a "Defined/structured agenda" and were statistically significant, $F(2,41)=8.54, p=.001$. The beta coefficients are presented in Table 7 . Note that these predictor variables significantly predict LEED points, $p<.050$. This means that charrettes that were "Held as LEED strategy/checklist meeting" $(B=-9.35)$ and had a "Defined/structured agenda" ( $B=-$ 13.48) earned less points than that of charrettes that did not included these characteristics. The $R^{2}$ 
value was .294; this indicates that $29 \%$ of the variance in LEED points was explained by the model.

Table 6

Intercorrelations, Means, and Standard Deviations for LEED Points and Short Charrette

Predictor Variables $(n=44)$

\begin{tabular}{|c|c|c|c|c|c|c|c|c|c|c|c|c|c|}
\hline Variable & 1 & 2 & 3 & 4 & 5 & 6 & 7 & 8 & 9 & 10 & 11 & $M$ & $S D$ \\
\hline 1. LEED Points & - & -.30 & -.04 & $-.34 *$ & .20 & -.02 & $-.46^{* *}$ & -.16 & -.07 & -.02 & -.22 & 62.89 & 13.53 \\
\hline $\begin{array}{l}\text { 2. Project goals defined } \\
\text { before the charrette takes } \\
\text { place }\end{array}$ & & - & -.04 & .04 & -.23 & -.13 & .20 & .28 & .13 & -.05 & $.40 * *$ & .70 & .46 \\
\hline $\begin{array}{l}\text { 3. Interdisciplinary or } \\
\text { specialty participants were } \\
\text { used }\end{array}$ & & & - & .22 & .04 & .01 & .08 & .10 & .00 & -.18 & .25 & .43 & .50 \\
\hline $\begin{array}{l}\text { 4. Defined/structured } \\
\text { agenda }\end{array}$ & & & & - & -.14 & .03 & .10 & .03 & .09 & -.09 & .09 & .80 & .41 \\
\hline 5. Brainstorming & & & & & - & .18 & .06 & .18 & -.09 & .03 & .06 & .77 & .42 \\
\hline $\begin{array}{l}\text { 6. Part of a series of } \\
\text { charrettes }\end{array}$ & & & & & & - & .00 & $.31^{*}$ & .20 & -.01 & .07 & .36 & .49 \\
\hline $\begin{array}{l}\text { 7. LEED strategy/LEED } \\
\text { checklist meeting }\end{array}$ & & & & & & & - & -.11 & -.11 & .00 & $.32 *$ & .75 & .44 \\
\hline $\begin{array}{l}\text { 8. Held as a "Kickoff" for } \\
\text { the building project }\end{array}$ & & & & & & & & - & .07 & -.13 & .20 & .36 & .49 \\
\hline $\begin{array}{l}\text { 9. Focused on one or more } \\
\text { specific aspects of the } \\
\text { building project }\end{array}$ & & & & & & & & & - & -.04 & -.02 & .84 & .37 \\
\hline $\begin{array}{l}\text { 10. Included few } \\
\text { participants }(<10 \text { People })\end{array}$ & & & & & & & & & & - & -.04 & .82 & .39 \\
\hline $\begin{array}{l}\text { 11. Targeted audience of } \\
\text { participants used }\end{array}$ & & & & & & & & & & & - & .84 & .37 \\
\hline
\end{tabular}

Note. $* p<.05 * * p<.01$ 
Table 7

Short Charrette Characteristic Predictors of LEED Points $(n=44)$

\begin{tabular}{|c|c|c|c|c|c|c|}
\hline \multirow[b]{2}{*}{ Variable } & \multicolumn{3}{|c|}{ Model 1} & \multicolumn{3}{|c|}{ Model 2} \\
\hline & $B$ & $S E B$ & $\beta$ & $B$ & $S E B$ & $\beta$ \\
\hline LEED Strategy/Checklist Meeting & $-14.33 * *$ & 4.22 & $-.46^{* *}$ & $-13.48 * *$ & 4.07 & $-.437 * *$ \\
\hline Defined/Structured Agenda & - & - & - & $-9.35^{*}$ & 4.37 & $-.28 *$ \\
\hline$R^{2}$ & \multicolumn{3}{|c|}{.22} & \multicolumn{3}{|c|}{.29} \\
\hline$F$ & \multicolumn{3}{|c|}{$11.53 * *$} & \multicolumn{3}{|c|}{$8.54 * *$} \\
\hline
\end{tabular}

Note. $* p<.05 \quad * * p<.01$

Long Charrette Analysis

Survey respondents whose projects conducted at least one Long Charrette $(n=14)$ during the design process were asked to select all characteristics that were typical of the Long Charrettes ( $>4$ hours) that were conducted for the building project in question. Characteristics listed were developed from the results of the focus group previously held. Figure 7 shows the percent of characteristics typically applied to Long Charrettes conducted. Most of the characteristics were applied in a large percent. Project stakeholders were present $100 \%$ of the time. 


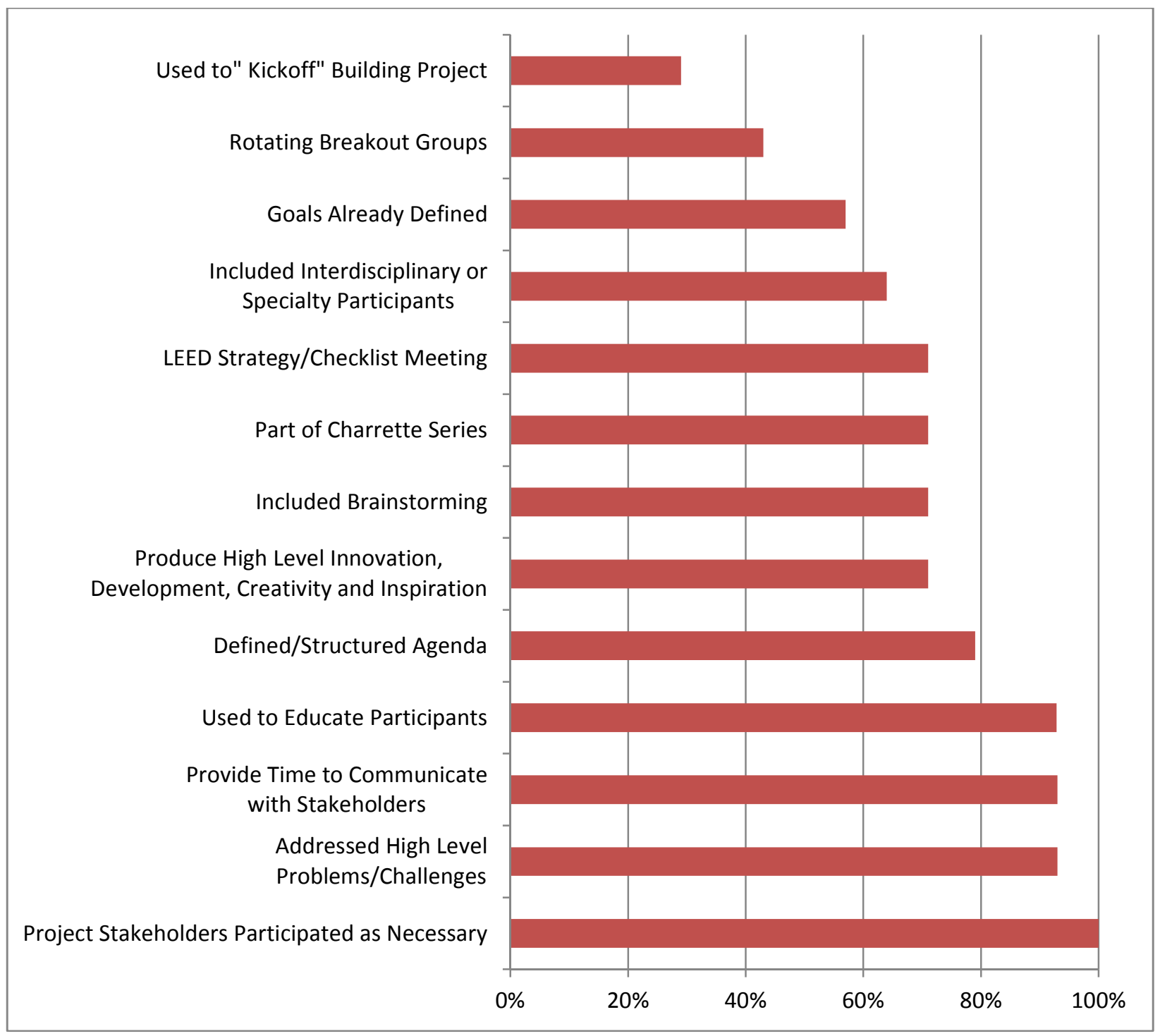

Figure 7. Percent of characteristics applied by Long Charrettes

Due to the exploratory nature of the research, the stepwise multiple regression method was used to investigate the best predictors of LEED points for Long Charrettes. The means, standard deviations and intercorrelations of LEED points and Long Charrette predictor variables (characteristics) can be found in Table 8. The best variable used to predict LEED points from "Project goals were already defined" and was statistically significant, $F(1,12)=5.06, p=.044$. The beta coefficient is presented in Table 9. Note that this predictor variable significantly predicts 
LEED points, $p<.050$. This means that charrettes having the characteristic of project goals before the charrette took place $(B=-17.5)$ earned less points than that of charrettes that did not include this characteristic. The $R^{2}$ value was .30 ; this indicates that $30 \%$ of the variance in LEED points was explained by the model.

Table 8

Intercorrelations, Means, and Standard Deviations for LEED Points and Long Charrette

Predictor Variables $(n=14)$

\begin{tabular}{|c|c|c|c|c|c|c|c|c|c|c|c|c|c|c|c|c|}
\hline Variable & 1 & 2 & 3 & 4 & 5 & 6 & 7 & 8 & 9 & 10 & 11 & 12 & 13 & 14 & $M$ & $S D$ \\
\hline 1. LEED Points & - & $-.55^{*}$ & .51 & .24 & .24 & .45 & .04 & .31 & .24 & .31 & -.01 & - & -.53 & .24 & 64.50 & 16.50 \\
\hline $\begin{array}{l}\text { 2. Project goals } \\
\text { defined before the } \\
\text { charrette takes } \\
\text { place }\end{array}$ & & - & -.34 & -.10 & -.23 & $-.55^{*}$ & -.23 & -.09 & -.24 & -.24 & .17 & - & .32 & -.23 & .57 & .51 \\
\hline $\begin{array}{l}\text { 3. Interdisciplinary } \\
\text { or specialty } \\
\text { participants were } \\
\text { used }\end{array}$ & & & - & .34 & -.14 & .52 & .19 & .14 & -.21 & .37 & .34 & - & -.21 & -.14 & .64 & .50 \\
\hline $\begin{array}{l}\text { 4. Defined/ } \\
\text { structured agenda }\end{array}$ & & & & - & .44 & .44 & .06 & -.06 & -.15 & .53 & .45 & - & -.15 & .44 & .79 & .43 \\
\hline 5. Brainstorming & & & & & - & .30 & .30 & .05 & .44 & -.18 & .23 & - & -.18 & $1.00 * *$ & .71 & .47 \\
\hline $\begin{array}{l}\text { 6. Part of a series } \\
\text { of charrettes }\end{array}$ & & & & & & - & $.65^{*}$ & .05 & .44 & .44 & .23 & - & -.18 & .30 & .71 & .47 \\
\hline $\begin{array}{l}\text { 7. LEED } \\
\text { strategy/LEED } \\
\text { checklist meeting }\end{array}$ & & & & & & & - & -.30 & .44 & -.18 & .23 & - & -.18 & .30 & .71 & .47 \\
\hline $\begin{array}{l}\text { 8. Held as a } \\
\text { "Kickoff" for the } \\
\text { building project }\end{array}$ & & & & & & & & - & .18 & .18 & .09 & - & .18 & .05 & .29 & .47 \\
\hline $\begin{array}{l}\text { 9. Educate the } \\
\text { participants about } \\
\text { the building project }\end{array}$ & & & & & & & & & - & -.08 & -.32 & - & -.08 & .44 & .93 & .27 \\
\hline $\begin{array}{l}\text { 10. Addressed high } \\
\text { level problems/ } \\
\text { challenges }\end{array}$ & & & & & & & & & & - & .24 & - & -.08 & -.18 & .93 & .27 \\
\hline
\end{tabular}


11. Rotating

breakout group

sessions are used

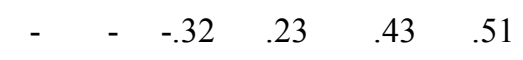

during the charrette

12. Stakeholders

participate as

necessary

throughout

charrettes

13. Provides

valuable time to

communicate with

$\begin{array}{llll}- & -.18 \quad .93 \quad .27\end{array}$

owners or owner

representatives

14. Produce high

level innovation,

development,

creativity and

inspiration

Note. ${ }^{*} p<.05 * * p<.01$, the characteristic "Stakeholders participate as necessary throughout charrettes" was present at each Long Charrette and is therefore a constant meaning no correlation can be computed.

Table 9

Long Charrette Characteristic Predictors of LEED Points $(n=14)$

\begin{tabular}{cccc}
\hline & \multicolumn{3}{c}{ Model 1 } \\
\cline { 2 - 4 } Variable & $B$ & $S E B$ & $\beta$ \\
\hline Project Goals Already Defined & $-17.50^{*}$ & 7.78 & $-.55^{*}$ \\
$R^{2}$ & & .30 \\
$F$ & & $5.06^{*}$ \\
\hline
\end{tabular}

Note. ${ }^{*} p<.05 * * p<.01$

Characteristics and LEED Points

To better understand the impact of excluding certain characteristics of the charrette process found to be impeding the amount of LEED points achieved, LEED point averages were assessed by focusing specifically on the exclusion of these certain characteristics. Table 10 shows the differences of LEED point averages across Short and Long Charrettes and also the 
averages of projects that did not include these specific characteristics in the charrette process.

This table represents the regression models and shows an average increase of LEED points when these characteristics are not present during the charrette. The point differences between charrettes and the exclusion of the variables that were predicted in the multiple regression models shows an increase in LEED points. This is found to be consistent with to relationship found in the multiple regression models; however, the magnitude of LEED points is different due to the use of actual data verses modeled outcomes.

Excluding the "LEED Strategy/Checklist Meeting” characteristic from Short Charrettes yielded 11.1 additional points on average. Excluding the "Defined/Structured Agenda" characteristic from Short charrettes yielded 8.9 additional points on average. Additionally, with the exclusion of the "Project Goals Already Defined" characteristic from Long Charrettes yielded an additional 10 points on average.

Table 10

LEED Point Average Comparison

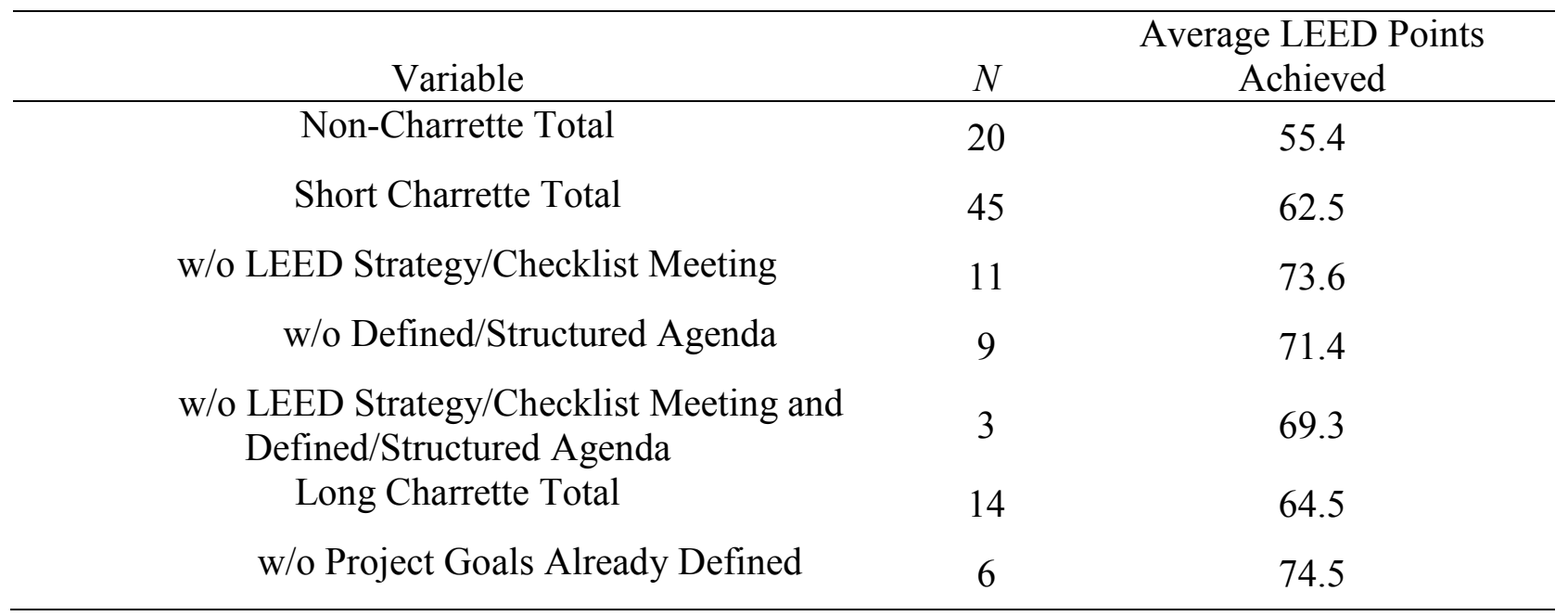




\section{Characteristic Comparison}

To understand the differences between the two types of charrettes, a graph was created to compare the same characteristics between groups. Figure 8 shows that most characteristics were reported in similar percentages for both charrette types. However, specialty participants and charrettes as part of a series of charrettes were reported in much higher numbers than that of Short Charrettes.

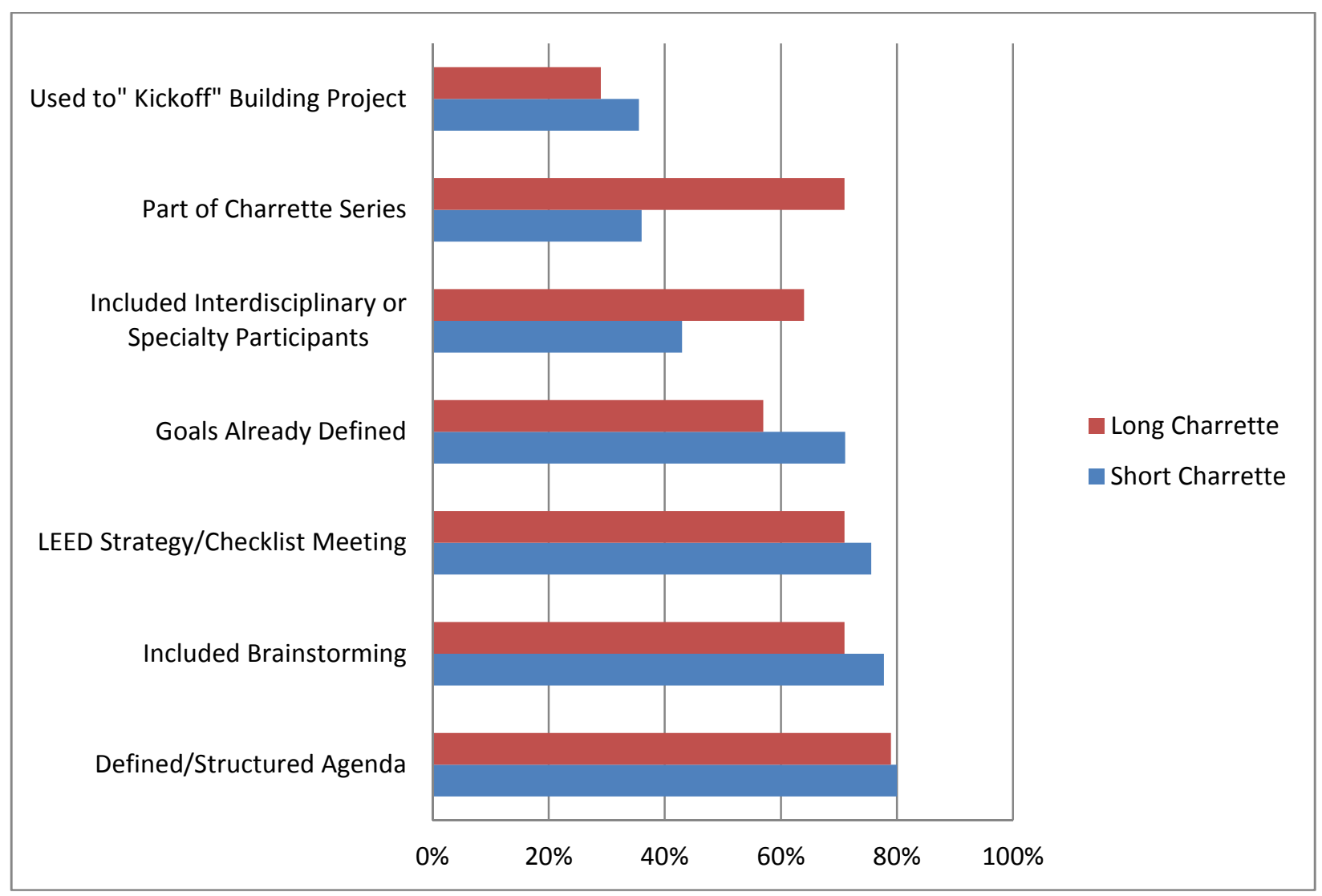

Figure 8. Comparison of common characteristics among charrette types 


\section{Charrette Follow-up Questions}

Respondents were asked to rate their agreement of six statements about the charrette process as it relates to LEED certification. Questions were formatted on a six point scale ("Strongly Agree"=1; "Strongly Disagree"=5; "Don't Know"=6), only one response was able to be selected. Answers have been analyzed and percentages for each question have been given. Table 11 summarizes the responses of each question.

Table 11

Questions for Projects Implementing Charrettes

\begin{tabular}{|c|c|c|c|c|c|c|}
\hline Questions & $\begin{array}{c}\text { Strongly } \\
\text { Agree }\end{array}$ & Agree & $\begin{array}{l}\text { Neither } \\
\text { Agree or } \\
\text { Disagree }\end{array}$ & Disagree & $\begin{array}{l}\text { Strongly } \\
\text { Disagree }\end{array}$ & $\begin{array}{l}\text { Don't } \\
\text { Know }\end{array}$ \\
\hline $\begin{array}{l}\text { 1. The design charrette(s) } \\
\text { were an important part of the } \\
\text { project's LEED certification. } \\
(n=46)\end{array}$ & $\begin{array}{c}37 \% \\
(n=17)\end{array}$ & $\begin{array}{c}46 \% \\
(n=21)\end{array}$ & $\begin{array}{l}15 \% \\
(n=7)\end{array}$ & $\begin{array}{c}2 \% \\
(n=1)\end{array}$ & $\begin{array}{c}0 \% \\
(n=0)\end{array}$ & $\begin{array}{c}0 \% \\
(n=0)\end{array}$ \\
\hline $\begin{array}{l}\text { 2. A higher level of } \\
\text { sustainability was achieved } \\
\text { because design charrettes } \\
\text { were conducted. }(n=45)\end{array}$ & $\begin{array}{c}31 \% \\
(n=14)\end{array}$ & $\begin{array}{c}42 \% \\
(n=19)\end{array}$ & $\begin{array}{l}20 \% \\
(n=9)\end{array}$ & $\begin{array}{c}7 \% \\
(n=3)\end{array}$ & $\begin{array}{c}0 \% \\
(n=0)\end{array}$ & $\begin{array}{c}0 \% \\
(n=0)\end{array}$ \\
\hline $\begin{array}{l}\text { 3. More LEED points were } \\
\text { achieved because design } \\
\text { charrettes were conducted. } \\
(n=46)\end{array}$ & $\begin{array}{c}26 \% \\
(n=12)\end{array}$ & $\begin{array}{c}39 \% \\
(n=18)\end{array}$ & $\begin{array}{c}26 \% \\
(n=12)\end{array}$ & $\begin{array}{c}9 \% \\
(n=4)\end{array}$ & $\begin{array}{c}0 \% \\
(n=0)\end{array}$ & $\begin{array}{c}0 \% \\
(n=0)\end{array}$ \\
\hline $\begin{array}{l}\text { 4. More LEED points would } \\
\text { have been achieved if only } \\
\text { the traditional design process } \\
\text { was used. }(n=46)\end{array}$ & $\begin{array}{c}2 \% \\
(n=1)\end{array}$ & $\begin{array}{c}0 \% \\
(n=0)\end{array}$ & $\begin{array}{l}20 \% \\
(n=9)\end{array}$ & $\begin{array}{c}39 \% \\
(n=18)\end{array}$ & $\begin{array}{c}39 \% \\
(n=18)\end{array}$ & $\begin{array}{c}0 \% \\
(n=0)\end{array}$ \\
\hline $\begin{array}{l}\text { 5. If more design charrettes } \\
\text { had been implemented, the } \\
\text { project could have attained } \\
\text { more LEED points. }(n=46)\end{array}$ & $\begin{array}{c}4 \% \\
(n=2)\end{array}$ & $\begin{array}{l}13 \% \\
(n=6)\end{array}$ & $\begin{array}{c}26 \% \\
(n=12)\end{array}$ & $\begin{array}{c}48 \% \\
(n=22)\end{array}$ & $\begin{array}{c}7 \% \\
(n=3)\end{array}$ & $\begin{array}{c}2 \% \\
(n=1)\end{array}$ \\
\hline $\begin{array}{l}\text { 6. If a higher quality design } \\
\text { charrette were implemented, } \\
\text { more LEED points could } \\
\text { have been attained. }(n=45)\end{array}$ & $\begin{array}{c}4 \% \\
(n=2)\end{array}$ & $\begin{array}{l}11 \% \\
(n=5)\end{array}$ & $\begin{array}{l}18 \% \\
(n=8)\end{array}$ & $\begin{array}{c}56 \% \\
(n=25)\end{array}$ & $\begin{array}{l}11 \% \\
(n=5)\end{array}$ & $\begin{array}{c}0 \% \\
(n=0)\end{array}$ \\
\hline
\end{tabular}


In question 1, respondents overwhelmingly agreed that charrettes conducted in the design process were an important part of the projects LEED certification, $74 \%(n=38)$ agreeing or strongly agreeing. In question 2 , the majority of respondents $73 \%(n=33)$ agreed or strongly agreed that charrette(s) helped the project reach a higher level of sustainability. In question 3, $65 \%(n=30)$ agreed or strongly agreed that more LEED points were attained because of the design charrettes conducted. These responses suggest the charrette process is very important to not only increase LEED points of a building projects but to also raise the level of sustainability. Further, when asked if the traditional design process would have increased the number of LEED points attained, in question 4 , the responses overwhelmingly indicated a disagreement $78 \%$ $(n=26)$.

In question 5, respondents were asked if more LEED points would have been attained if more charrettes had been implemented. The answers were mixed with $55 \%(n=25)$ disagreeing or strongly disagreeing, 26\% $(n=12)$ neither agreeing nor disagreeing and $17 \%(n=8)$ agreeing or strongly agreeing. In question 6 , respondents were asked if the quality of the charrette would have increased the amount of LEED points attained. Respondents indicated that the quality did not increase LEED points with $67 \%(n=30)$ disagreeing or strongly disagreeing with the statement.

\section{Networking}

To understand the interconnectedness of the charrette participants, survey respondents were asked to identify the level of personal connections of charrette participants. The question asked: "Were charrette participants highly networked (having many personal connections) or not very networked (having few personal connections) at the beginning [end] of the charrette process?" Answer options were formatted on a six point scale ("Many Connections"=1; "No 
Connections"=5; "Don't Know"=6). Figure 9 shows personal connections of charrette participants before the charrette process took place and after the charrette process took place. The majority of projects are located within the Many Connections and Some Connections range before the charrette process took place. However, after the charrettes took place a higher percentage of projects were reported in the Many Connections and Some Connections range. This indicates a higher level of interconnectedness between the participants following the charrette process.

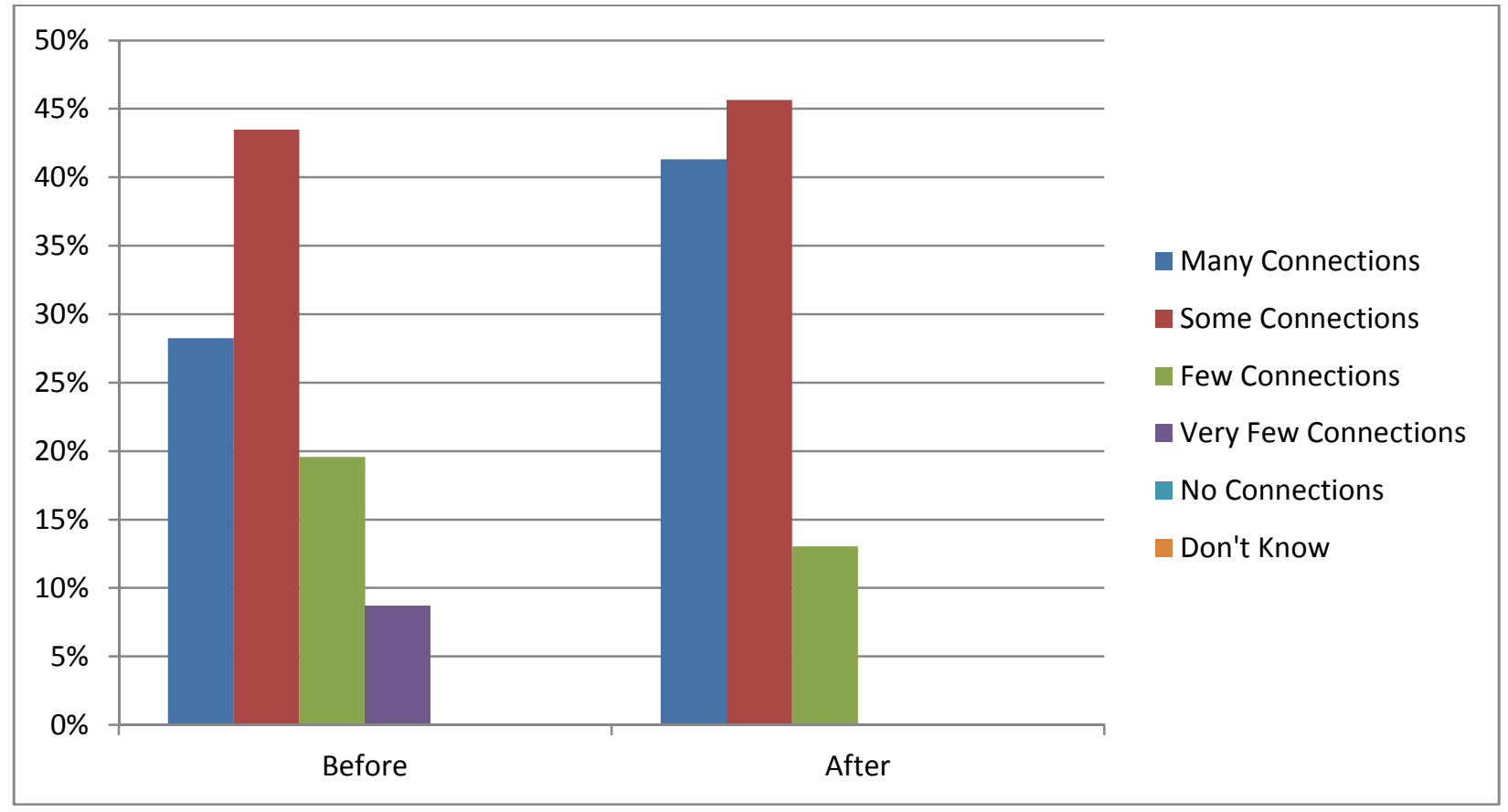

Figure 9. Building projects by networking category

LEED point means were also calculated for each networking category as shown in Figure 10. Having some personal connections before the charrette process takes place is advantageous in attaining more LEED points as compared to the other networking categories. This category of building projects attained six more LEED points than other projects in the other categories. 


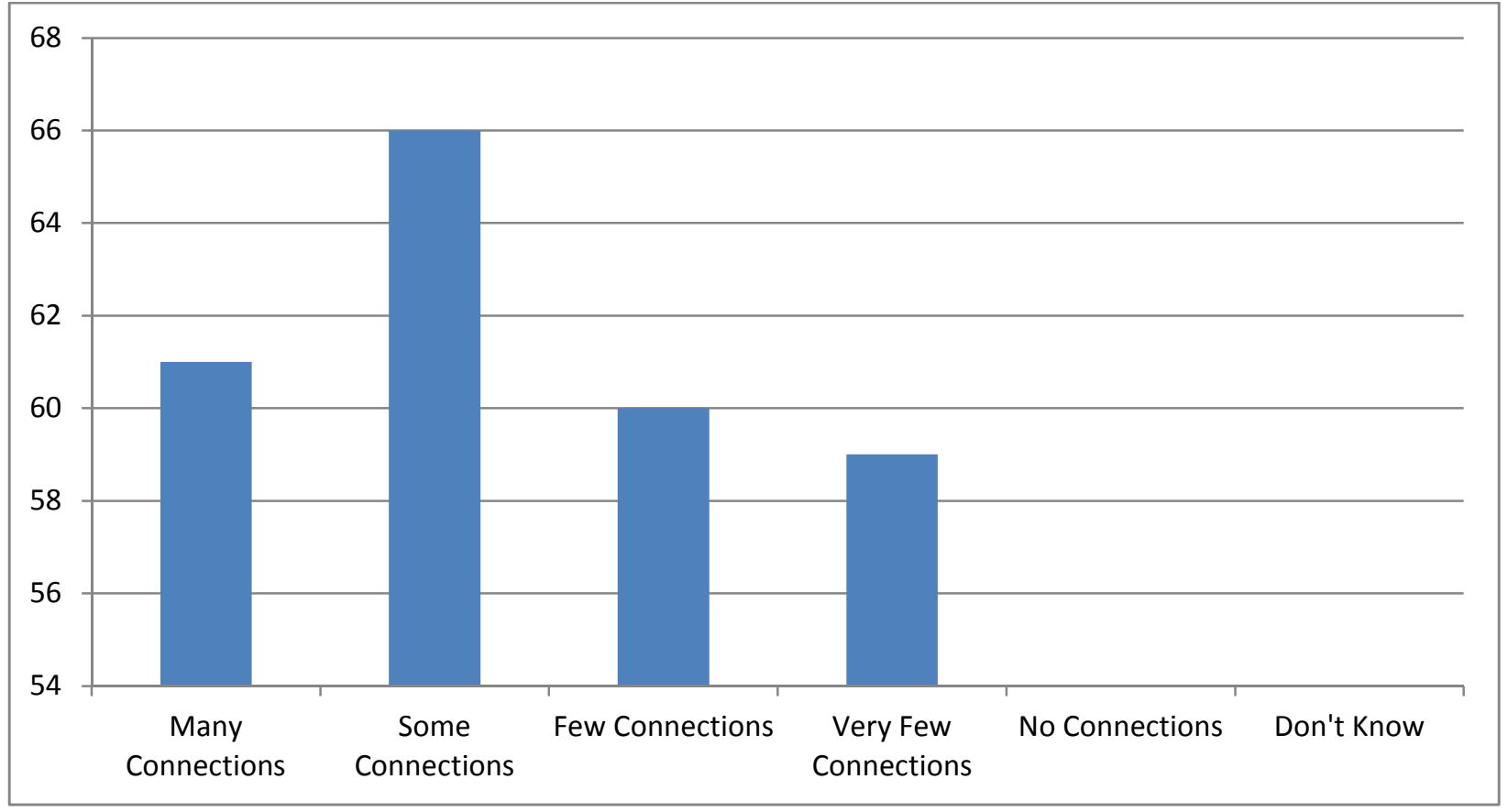

Figure 10. Average LEED points per networking category

\section{Open-ended Charrette Questions}

Open-ended questions were asked to all respondents whose projects implemented at least one charrette during the design of the building project. Responses were coded and categorized into common themes. Themes of open-ended questions are summarized below. Actual responses are located in Appendix L.

1. In your opinion, what were the benefits to conducting design charrette(s) during the design of the building project in question?

Forty survey respondents answered this question. Many different benefits to conducting a charrette were stated in the responses; however, goal setting was among the most cited responses. It was beneficial for the charrette team to create the goals and "establish the direction" of the project. It was mentioned that "establishing the sustainability goals prior to beginning 
design lead to fully integrated solutions." Understanding project goals or vision, different than goal setting, was also mentioned several times as a benefit; these goals seemed to suggest they were complete before the charrette process began and were communicated to the team by an outside party. In one case, the charrettes helped enforce the goals set by the owner.

Charrettes also encouraged buy-in from all charrette participants. One respondent mentioned, "well-designed, good projects employ charrette thinking to achieve team member buy-in." Communication was another large benefit to the charrette process, as stated in the responses, by allowing for more direct communication among the design team professionals. Immediate feedback from charrette team members resulted in faster decision-making and solutions to problems where the charrette "allowed for rapid review of many more alternative schemes or design solutions" and where "most decisions can be made on the spot." Brainstorming was also a key benefit to the charrette process allowing for solutions to complex and challenging problems.

\section{In your opinion, what were the challenges/problems in conducting design charrette(s) during the design of the building project in question?}

Thirty-eight survey respondents answered this question. The most common challenge or problem during the charrette process was schedule coordination and time constraints of charrette participants. Reponses suggested that charrette team members were very busy and were "hesitant to agree to long collaborative sessions." One respondent mentioned that it was difficult to get team members to agree to "spend more than 3 hours in a meeting." It was also difficult to synchronize all the team members busy schedules around a common charrette time. In several cases, a challenge was created by owners that were reluctant to pay the additional costs of holding a charrette. 
Several responses indicated that some participants were "stuck-on" certain ideas and were unwilling to consider other options. Education of owners and other charrette participants seemed to be a common challenge during this process. Another common challenge seemed to stem from the cost implications ideas and the need to provide a cost estimate before making decisions. There were also many responses that did not cite any challenges or problems during the charrette process.

\section{Do you have any suggestions for conducting successful design charrettes focused on} producing LEED certified buildings?

Thirty-five survey respondents answered this question. The most common suggestion for conducting successful design charrettes for LEED certified buildings was to implement the charrette early in the design process, allowing all participants to become aware and more easily focused on the goals at hand, "the earlier in the process the better."

Interestingly, several responses suggested that LEED should not be the main focus of the charrette process. One respondent said "LEED discussions should be held independently from design charrettes," while another said its "important not to lose sight of other sustainability related goals that fall outside of LEED.” Additional suggestions included having a good charrette facilitator, preparing the charrette ahead of time, and using breakout groups of smaller numbers of participants to focus on a specific aspect of the project. Inviting the right people or inviting a broad variety of charrette participants was cited as beneficial. 


\section{CHAPTER V}

\section{DISCUSSION AND CONCLUSION}

This research set out to answer "what relationship, if any, exists between holding a charrette during the design process to the level (i.e. points) of LEED certification achieved?" Research was conducted in two phases to answer this question. A focus group of charrette experts was conducted in Phase I to narrow down important variables (characteristics) of the charrette process when designing for LEED certified buildings. Phase II used a quantitative approach by sending a survey to building project representatives of LEED certified buildings, they were asked to answer questions about the charrette process, and charrette characteristics as it relates to LEED outcomes.

\section{Study Findings}

Through the literature review and through experts in a focus group, charrettes could be categorized into two separate definitions to design LEED certified building projects. The length of the charrette distinguishes them. Reasons for the differences in length were linked to the challenges of assembling charrette participants for shorter periods of time verses a longer periods of time, what the research refers to as a Short Charrette and a Long Charrette. The focus group identified ten specific characteristics for Short Charrettes and thirteen specific characteristics for Long Charrettes as the most important characteristics when designing LEED certified buildings.

Looking broadly at the charrette process and its impacts on the level of LEED points achieved revealed a significant difference between the amounts of LEED points achieved for projects implementing charrettes compared to projects not implementing charrettes. On average, implementing at least one charrette during the design process yielded approximately seven more 
LEED points than these projects which did not implement a charrette. This finding was reinforced qualitatively in responses to survey questions that asked survey respondents they if they believed more points were achieved because charrettes were used; $65 \%$ agreed or strongly agreed to the question (Table 11). However, implementing a larger number of charrettes on a given project did not significantly increase the number of LEED points achieved (Table 4). Of the projects surveyed, charrettes were typically conducted at the earlier stages of the design process with the majority conducted during schematic design (Figure 3).

\section{Response to Research Sub-questions}

RQ1: Are there important characteristics of charrettes related to LEED certification?

Focus group discussions surrounding the two types of charrettes yielded a different list of characteristics, identified as the most important when designing for LEED certified buildings. Seven characteristics were common for both types.

The most important Short Charrette characteristics identified were (with the seven in common, listed first): defined project goals before the charrette takes place, interdisciplinary or specialty participants, having a defined or structured agenda, brainstorming, part of a series of charrettes, LEED strategy or LEED checklist meeting, held as a "Kickoff" for the building project, focus on one or more specific aspects of the building project, few participants $(<10$ people), and targeted audience of participants.

The most important Long Charrette characteristics identified were (with the seven in common, listed first): defined project goals before the charrette takes place, interdisciplinary or specialty participants, having a defined or structured agenda, brainstorming, part of a series of charrettes, LEED strategy or LEED checklist meeting, held as a "Kickoff" for the building project, educated participants about the building project, address high level problems or 
challenges, project stakeholders participate as necessary, provides valuable time to communicate with owner or owner representatives, and produce high level innovation, development, creativity and inspiration.

RQ2: Is there a relationship between these characteristics and LEED project certification?

Multiple regression analysis was performed for each charrette type in an effort to find which characteristics were the best predictors for LEED outcomes (i.e. points). Out of the 10 characteristics identified in the focus group for Short Charrettes, two characteristics were, in fact, shown to have a negative effect on LEED points when included in Short Charrettes, they were, a) holding a charrette as a LEED strategy or LEED checklist meeting, and b) having a defined or structured agenda. Including both characteristics in the regression model lowered the number of LEED points achieved by 22.83 points. This number was calculated by adding both $B$ coefficients together from Model 2 found in Table 7. These characteristics, therefore, have a large negative impact on the number of LEED points achieved. Including both characteristics in the Short Charrette process could hinder a projects ability to achieve a high level of LEED certification. This may be due to the constraining effects of these specific characteristics. This amount of points could easily lower a projects certification by one or two levels. However, the remaining eight characteristics identified for Short Charrettes did not significantly affect the level of LEED certification achieved in either a positive or negative way.

Out of the 13 characteristics identified in the focus group for Long Charrettes, one characteristic was shown to have a negative effect on LEED points when included in Long Charrettes, a) project goals already defined prior to the charrette(s). Including this characteristic in the regression model lowered the number of LEED points achieved by 17.50. This number, coefficient $B$, can be found in Table 9. This characteristic also has a large impact to the number 
of LEED points achieved and could hinder a projects ability to achieve a high level of LEED certification. Again, the remaining twelve characteristics identified for Long Charrettes did not significantly affect the level of LEED certification achieved in either a positive or negative way. Project goals defined before a charrette takes place may limit the creative goal setting that could occur in the charrette process thus reducing LEED points.

\section{Discussion}

There are many different factors to consider when implementing the charrette process during the design of a LEED certified building. The results of this study confirm Pettit's previous finding that implementing at least one charrette has a significant positive impact on LEED certification and points achieved. Three charrette characteristics, however, were shown to reduce this positive impact significantly. These characteristics were: a) using the charrette as a LEED checklist meeting, b) defined/structured agenda and c) project goals already defined before the charrette process takes place. These factors can all be viewed as limiting factors since they are narrowing the scope of what happens during a charrette.

For example, using a charrette as a LEED checklist meeting may limit a group's ability to consider other sustainable strategies and items outside the LEED certification system. Not only was this found in the quantitative analysis, qualitative responses also indicated charrettes should not focus on the LEED certification aspect while holding a charrette. Having a strictly defined or structured agenda may also lead charrette participants to contain their focus on several items on an agenda and limit creativity and systems thinking. Also, a common theme among survey respondents who answered an open-ended question mentioned that LEED should be a by-product of the charrette process, not the focus. Having pre-defined goals before the charrette process takes place was another limiting factor identified. Important project goals made before the 
charrette occurs may not mirror goals that charrette participants would set and may not reinforce full project team buy-in, a critical element to successfully integrated building projects.

Results suggest the charrette process has the potential to provide significant benefits regardless of what characteristics are implemented, but to fully realize this benefit, the charrette should not include factors that are limiting to a group's ability to produce creative ideas, goals, and solutions. Thus, charrettes are best conducted to allow for open-ended conversations, brainstorming and creative solutions to problems that can be vetted thoroughly and rapidly among many people with interdisciplinary backgrounds.

One interesting finding in the analysis was that increasing the number of charrettes implemented did not significantly increase the amount of LEED points achieved for building projects. This could be due to a culture of interdisciplinary action and not the charrettes themselves. While the charrette provides a vehicle for an integrated design team to meet, design, and problem solve in the same room, if an integrated design process is being implemented, open channels of communication across the disciplines may continue to be supported outside of charrette events. Thus, the charrette appears to aid in the design process, but the integrated design process itself may be the main driver of increased LEED points. Further research could be conducted to evaluate the integrated design process versus the charrette process and versus traditional design processes to evaluate its impacts in isolation.

\section{Conceptual Charrette Process Model}

The conceptual process model presented in Figure 11 was adapted from the model presented earlier in Chapter 1, Figure 1. Characteristics found to be significant in the study turned out to be negatively correlated with LEED points; however, other characteristics studied did not prove to significantly affect LEED points either positively or negatively. Therefore, it can 
be assumed that there are characteristics known and unknown to effect outcomes of the charrette process. The model was updated to reflect these findings.

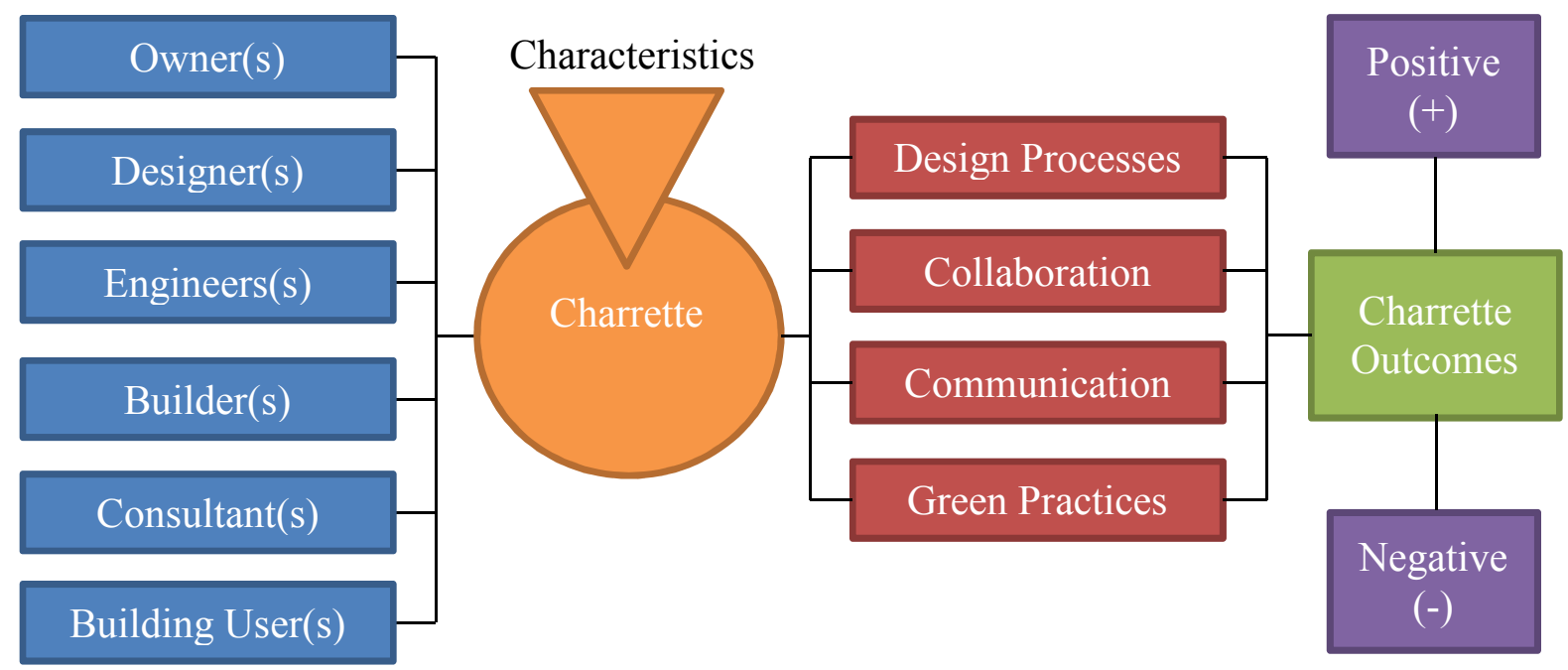

Figure 11. Conceptual charrette process model (Knox, 2013)

\section{Implications}

The implications of this study are much wider than the LEED certification process alone. Charrettes are already used in non-certified, sustainable, and non-sustainable building projects. Results of this study suggest that charrettes are beneficial to outcomes of LEED certified building projects but the benefits of the charrette process can be extended to any project where interdisciplinary design and creative problem-solving takes place. Based on a targeted literature review along with quantitative and qualitative findings, charrettes increase the early interactions of project teams and often lead to collaborative goal-setting and decision-making, important components in the complex process of design and construction of building projects.

\section{Limitations}

Limitations potentially affecting data collected include the use of a convenience sample. Region, climate, and size of building project surveyed were not taken into consideration. LEED 
buildings identified as "Confidential" by the USGBC were not included in the study because information was not accessible.

Initial collection of building projects surveyed may potentially be skewed towards the number of projects implementing charrettes verses projects not implementing charrettes. Initial emails to potential project contacts could have yielded a greater number of responses from projects implementing a charrette because of the language used in the email script (Appendix E). Contacts from projects not implementing a charrette may have thought that the survey was not applicable to them and did not respond. This would potentially result in a higher percentage of esurveys returned from projects implementing charrettes.

\section{Recommendations for Future Research}

Due to the limited research conducted specifically on the charrette process and the relationship to LEED or sustainable building projects, there is more potential to do related research. Future research questions could include: What is the best way to conduct a design charrette for green building projects? What is the best balance of structure during a charrette? Is there an optimal duration of charrettes? Does the charrette process typically develop trust and better communication between participants? Do feedback loops and open communication lines between disciplines inherent in a successful charrette typically continue after a charrette ends? How does the interconnectedness of the charrette group relate to project outcomes? Do projects, which use a strong integrative design process, result in higher levels of LEED? If so, how many LEED points, on average, does the integrated process contribute to a LEED project?

\section{Summary}

As an exploratory study, this research has begun to shed light on "what relationship, if any, exists between holding a charrette during a building project's design process to the level 
(i.e. points) of LEED certification achieved?" The findings, both quantitative and qualitative, indicate that there is a positive relationship between the use of charrettes during the design process with an increase, on average, of over seven LEED points achieved. This relationship confirms a previous relationship found in a similar study conducted in 2003 which also found that charrettes increase the level of LEED certification a building project achieved (Pettit, 2003). In addition, the research study identified three factors that appear to negatively affect LEED project outcomes. a) holding a charrette as a LEED strategy or LEED checklist meeting, b) having a defined or structured agenda and c) project goals already defined prior to the charrette(s). The factors found to be significant have given an insight to better ways to conduct charrettes; these include keeping charrettes open-ended and less structured and refraining from using the LEED rating system and its checklist as the focus of a charrette. 


\section{REFERENCES}

AIA California Council. (2007). Integrated Project Delivery - A Working Definition. Retrieved 2/4/2012 http://ipd-ca.net/images/Integrated\%20Project\%20Delivery\%20Definition.pdf

Creswell, J. W. (2009). Research design: qualitative, quantitative, and mixed methods approaches (3rd ed.). Thousand Oaks, Calif.: Sage Publications.

Edward Gibson Jr, \& Gebken II, R. (2003). Design quality in pre-project planning: applications of the Project Definition Rating Index. [Article]. Building Research \& Information, 31(5), 346.

Elvin, G. (2007). Integrated practice in architecture : mastering design-build, fast-track and building information modeling. Hoboken: J. Wiley \& Sons.

Fong, P. S. W. (2003). Knowledge creation in multidisciplinary project teams: an empirical study of the processes and their dynamic interrelationships. International Journal of Project Management, 21(7), 479-486. doi: Doi: 10.1016/s0263-7863(03)00047-4

Fowler, F. J. (2009). Survey research methods (4th ed.). Thousand Oaks: Sage Publications.

Fuerst, F. (2009). Building momentum: An analysis of investment trends in LEED and Energy Star-certified properties. Journal Retail Leisure Property, 8(4), 285-297.

Fuerst, F., \& McAllister, P. (2011). Green Noise or Green Value? Measuring the Effects of Environmental Certification on Office Values. Real Estate Economics, 39(1), 45-69. doi: 10.1111/j.1540-6229.2010.00286.x

Gibson, E., \& Gebken, R. (2003). Planning Charrettes Using the Project Definition Rating Index. 116, 32 . 
Gibson, E., \& Whittington, D. A. (2010). Charrettes as a Method for Engaging Industry in Best Practices Research. Journal of Construction Engineering and Management, 136(1), 6675.

Green Building Certification Institute. (2011). GBCI: Green Building Certification Institute Retrieved 2/5/2012, from http://www.gbci.org/Homepage.aspx

Green Building Initiative. (2012). Green Globes Retrieved 2/4/2012, from http://www.thegbi.org/green-globes/

Hennink, M. M. (2007). International focus group research : a handbook for the health and social sciences. Cambridge: Cambridge University Press.

IBM Corporation. (2011). IBM SPSS Statistics for Windows (Version Version 20.0). Armonk, NY: IBM Corp.

International Living Future Institute. (2010). Living Building Challenge is... Retrieved 2/4/2012, from https://ilbi.org/lbc

Kanagaraj, G., \& Mahalingam, A. (2011). Designing energy efficient commercial buildings-A systems framework. Energy and Buildings, 43(9), 2329-2343. doi:

10.1016/j.enbuild.2011.05.023

Kibert, C. (2008). Sustainable construction: Green building design and delivery: Wiley.

Konchar, M., \& Sanvido, V. (1998). Comparison of U.S. Project Delivery Systems. Journal of Construction Engineering and Management, 124(6), 435-444.

Lennertz, W. R., Lutzenhiser, A., \& National Charrette, I. (2006). The Charrette Handbook: The Essential Guide for Accelerated, Collaborative Community Planning. Chicago, Ill.; Washington, D.C.: American Planning Association. 
Lindsey, G., Todd, J., \& Hayter, S. (2009). Handbook for Planning and Conducting Charrettes for High-Performance Projects: National Renewable Energy Laboratory (NREL), Golden, CO.

Newsham, G. R., Mancini, S., \& Birt, B. J. (2009). Do LEED-certified buildings save energy? Yes, but.... Energy and Buildings, 41(8), 897-905. doi: 10.1016/j.enbuild.2009.03.014

Orcher, L. (2005). Conducting research: Social and behavioral science methods: Pyrczak Publishing.

Pena, W. M., \& Parshall, S. A. (2001). Problem seeking: an architectural programming primer: Wiley.

Pettit, K. (2003). Investigating the relationship of charrettes and LEED certified buildings. (Masters Thesis), Colorado State University, Unpublished.

Pulaski, M. H., Horman, M. J., \& Riley, D. R. (2006). Constructability Practices to Manage Sustainable Building Knowledge (Vol. 12): ASCE.

Reed, B., \& et al. (2009). The integrative design guide to green building redefining the practice of sustainability. Hoboken, N.J.: Wiley.

Robichaud, L. B., \& Anantatmula, V. S. (2011). Greening Project Management Practices for Sustainable Construction. [Article]. Journal of Management in Engineering, 27(1), 4857. doi: $10.1061 /($ asce)me.1943-5479.0000030

Rohracher, H. (2001). Managing the Technological Transition to Sustainable Construction of Buildings: A Socio-Technical Perspective. [Article]. Technology Analysis \& Strategic Management, 13(1), 137-150. doi: Doi:10.1080/09537320120040491

Rossi, R. M., Brown, D., Park, B., \& Boser, R. (2009). The Integrated Design Process on Paper and In Practice: A Case Study. 
RSMeans. (2011). Green building : project planning \& cost estimating (3rd ed.). Hoboken, N.J.: RSMeans : Wiley.

Stewart, D. W., Rook, D. W., \& Shamdasani, P. N. (2006). Focus groups: Theory and practice (Vol. 20): Sage Publications, Incorporated.

The American Institute of Architects. (2007). Integrated Project Delivery: A Guide Retrieved from http://www.aia.org/contractdocs/AIAS077630

The Fannie Mae Foundation. (2003). Charrettes 101: Dynamic Planning for Community Change. Building Blocks, 4(1). Retrieved from www.fanniemaefoundation.org

U.S. Green Building Council. (2011). LEED is Global Retrieved 3/10/2013, from www.usgbc.org/leedisglobal

U.S. Green Building Council. (2013a). About USGBC Retrieved 2/11/2013, from http://new.usgbc.org/about

U.S. Green Building Council. (2013b). Integrative Process Retrieved 2/11/2013, from http://new.usgbc.org/node/2613097?return=/credits

U.S. Green Building Council. (2013c). USGBC: LEED Retrieved 2/11/2013, from http://new.usgbc.org/leed

Wallas, G. (1926). The art of thought. New York: Harcourt, Brace and Company.

Watson, D., \& American Institute of Architects. (1996). Environmental design charrette workbook. [Washington, D.C.]: AIA Committee on the Environment.

Yates, J. K., \& Battersby, L. C. (2003). Master Builder Project Delivery System and Designer Construction Knowledge. Journal of Construction Engineering and Management, 129(6), 635-644.

Yudelson, J. (2009). Green building through integrated design. New York: McGraw-Hill. 
APPENDICES 


\section{Appendix A: Focus Group Email Recruitment Script}

Title: Charrette Research Focus Group- Help Needed

Dear [name],

My name is Michael Knox and I am a graduate student at Colorado State University in the Department of Construction Management. I am conducting a research study on how design charrettes influence LEED certified buildings. The title of my project is "The Impact of Charrette Characteristics on Achieved LEED Certification." The results of the study will reveal the impact that certain characteristics of the charrette process have on LEED certified buildings.

Brian Dunbar, Executive Director for the CSU Institute for the Built Environment, has given me your name because he has identified you as someone who has contributed to sustainable design charrettes and believes you are an expert in the subject. The reason I am contacting you is that I will be holding a focus group discussion and would like for you to participate and share your experiences with the charrette process. At the end of the research study, we will send you our results and findings.

The intent of the focus group will be to explore the characteristics of the charrette process and to then identify those characteristics that are especially important in designing for LEED certified buildings. The focus group is expected to last approximately $1-1 / 2$ hours and participation in the study is voluntary.

We anticipate that the group discussion will be held during the week of April 16-20 and be publically located in the Fort Collins area. If you are able to participate in the focus group, please RSVP by filling out your availability on Doodle.com by going to http://www.doodle.com/38d9sdcpir3f4qvt, instructions are posted online. We will select a mutual time based the responses and will then send a follow up email confirming the selected time and place of the focus group. We will provide pizza and beverages for all participants.

\section{If you know of anyone else that you would consider a "charrette expert" and may be interested in participating, please forward this email to them, we would love for them to participate as well!}

If you have any questions, please contact Michael Knox at 720-935-3994 or fortknox0024@gmail.com. If you have any questions about your rights as a volunteer in this research, contact Janell Barker, Human Research Administrator, at 970-491-1655. I will be following up with a phone call next week to answer any questions you might have.

Sincerely,

Michael Knox

Graduate Student

Department of Construction Management

Colorado State University
Brian Dunbar

Executive Director

Institute for the Built Environment

Colorado State University 


\title{
Appendix B: Focus Group Consent Letter
}

\author{
Consent to Participate in a Research Study \\ Colorado State University
}

TITLE OF STUDY: Impact of Charrette Characteristics on Achieved LEED Certification

PRINCIPAL INVESTIGATOR: Caroline Clevenger, PhD, CSU Construction Management Dept., carcline clevenger@cabstate edu

CO-PRINCIPAL INVESTIGATOR: Michael Knox, Graduate Student, CSU Construction Management Dept., fortknox0024@gmail.com

WHAT IS THE PURPOSE OF THIS STUDY? The research will study the how certain charrette characteristics impact the level of LEED certification a building receives.

WHY AM I BEING INVITED TO TAKE PART IN THIS RESEARCH? If you are being asked to participate in the research, it is because you are thought to have working knowledge or experience relative to the charrette process.

WHERE IS THE STUDY GOING TO TAKE PLACE AND HOW LONG WLL IT LAST? The focus group will take place at location in Fort Collins, $\mathrm{CO}$.

WHAT WLL I BE ASKED TO DO? You will be asked to participate in a focus group that will last approximately $1-1 / 2$ hours. You will be asked questions that relate to the charrette process and LEED certification. At the end of the focus group you will also be asked to fill out a short survey that will take approximately five minutes.

ARE THERE ANY REASONS WHY I SHOULD NOT TAKE PART IN THIS STUDY? You should only participate in this study if you have working knowledge or experience relative to the charrette process.

WHAT ARE THE POSSIBLE RISKS AND DISCOMFORTS? There are no known risks to this research. However, it is not possible to identify all potential risks in research procedures, but the researcher(s) have taken reasonable safeguards to minimize any known and potential, but unknown, risks.

ARE THERE ANY BENEFITS FROM TAKING PART IN THIS STUDY? There are no direct benefits to participating in the research.

DO I HAVE TO TAKE PART IN THE STUDY? Your participation in this research is voluntary. If you decide to participate in the study, you may withdraw your consent and stop participating at any time without penalty or loss of benefits to which you are otherwise entitled.

WHO WLL SEE THE INFORMATION THAT I GIVE? Your information will be combined with information from other people taking part in the study. No personal information will be linked to the data collected during the session. The data for this project will not be kept with any identifiable personal information. The researcher intends to publish the results of this study.

WHAT HAPPENS IF I AM INJURED BECAUSE OF THE RESEARCH? Should you become injured because of this research, the Colorado Governmental Immunity Act determines and may limit Colorado State University's legal responsibility if an injury happens because of this study. Claims against the University must be filed within 180 days of injury. 
WHAT IF I HAVE QUESTIONS?

Before you decide whether to accept this invitation to take part in the study, please ask any questions that might come to mind now. Later, if you have questions about the study, you can contact the investigator, Michael Knox at fortknox0024@gmail.com. If you have any questions about your rights as a volunteer in this research, contact Janell Barker, Human Research

Administrator at 970-491-1655. We will give you a copy of this consent form to take with you. This consent form was approved by the CSU Institutional Review Board for the protection of human subjects in research on.

Your signature acknowledges that you have read the information stated and willingly sign this consent form. Your signature also acknowledges that you have received, on the date signed, a copy of this document containing 2 pages.

Date

$\overline{\text { Printed name of person agreeing to take part in the study }}$

Name of person providing information to participant

Date

Signature of Research Staff

Page $\mathbf{2}$ of $\mathbf{2}$ Participant's initials Date 


\section{Appendix C: Focus Group Script}

"Welcome and thank you for taking the time out of your day to participate in this focus group. My name is Michael Knox and I am a graduate student at Colorado State University studying Construction Management, I will be conducting this focus group as part of a research project.

The purpose of this focus group is to get your thoughts and feedback about the charrette process. More specifically, we want to understand how the charrette process influences the design of LEED Certified buildings and what characteristics will positively impact the level of LEED certification a building receives. The results of this focus group will be used as part of a Master's thesis, your participation and feedback is crucial as it will serve as a base for the rest of the study.

I would like to say that there is no right or wrong answers to the questions in this discussion, we will be simply interested in your views, opinions and experiences on charrettes so please feel free to say what you like. During the discussion we will be talking notes.

We would like to spend about one to one and a half hours discussing these questions and then there will be a quick questionnaire at the end. Please help yourself to the refreshments we have provided during the session. Are there any questions? Before we begin why don't we quickly go around the room and introduce ourselves..."

- The first question I would like to ask the group is how do you define a charrette?

- Now that we have defined the charrette, I would like to discuss what characteristics of charrettes you find the most important when be designing for LEED certified buildings. Please describe the characteristics for each type of charrette. 
"We are now reaching the end of our discussion; does anyone have any further questions or comments to add before we end this session? I would like to thank all of you very much for participation in this focus group, your views, opinions and experiences are all very valuable to assist in clarifying the link between charrettes and LEED certification. The last thing we have for you is to fill out a quick survey; you may leave after it has been completed. Thank you!" 


\section{Appendix D: Focus Group Survey}

1. How many years have you been involved with green building?

2. How many years have you been involved with charrettes?

3. How many "Short Charrettes" have you been a part of?

4. How many "Long Charrettes" have you been a part of?

5. What has been your role in those charrettes? (select all that apply)
$\circ$ Facilitator
- Owner
○ Consultant
$\circ$ Architect
○ Interior Designer
○ Landscape Designer
$\circ$ Engineer
- Construction Manager
○ Builder
- Commissioning Agent
○ Community Member
$\circ$ Building Occupant
$\circ$ Other (please specify)

6. Please rate your experience level of the following (No Experience, Not Very Experienced, Experienced, Very Experienced):
○ Charrette Process
$\circ$ Green Building 


\section{Appendix E: Initial Email Recruitment Script}

Title: [Project Name]- LEED

[Name],

My name is Michael Knox and I am a graduate student at Colorado State University in the Department of Construction Management. I am conducting a research study on how design charrettes influence LEED certified buildings. The title of my project is "Impact of Charrette Characteristics on Achieved LEED Certification." The results of the study will reveal the impact that certain characteristics of the charrette process have on LEED certified buildings.

I am looking for contact information of people who have been part of the design process of certain LEED (NC v2009 certified) projects for which I can send a survey to within the next couple of months. I am interested in collecting data on the [Project Name] which was certified in [Month/Year]. From what I have found, it looks like [Company Name] were the designers of this building.

Could you help me in my search to make a contact with someone that would best be able to take the survey? It could be anyone that was part of the design process such as the consultant, architect, engineer, LEED administrator, builder, etc.

If you have any questions, please do not hesitate to contact me at 720-935-3994.

Thank you, Michael Knox 


\section{Appendix F: E-Survey Email Recruitment Script}

Title: LEED Research Study- Chance to Win a \$50 Amazon Gift Card

Dear [FirstName] [LastName],

My name is Michael Knox and I am a graduate student at Colorado State University in the Department of Construction Management. I am conducting a research study on the characteristics of charrettes and how these characteristics influence the LEED rating level achieved by certain projects. The title of my project is "Impact of Charrette Characteristics on Achieved LEED Certification." The results of the study will indicate the potential impact of charrette characteristics on LEED points earned.

You have been contacted because you were identified as a project contact for the [CustomData]. I am surveying all recently certified LEED-NC v2009 building project contacts and would like for you to participate. Even if you believe that a charrette was not conducted on this building, it is important that you still complete the survey so that the results are representative of all LEEDNC v2009 projects. If possible, please forward this email to the appropriate person if you did not participate in this project; the survey should only be filled out once per project.

AFTER COMPLETING THE SURVEY, YOU MAY CHOOSE TO ENTER TO WIN A \$50 AMAZON GIFT CARD. DRAWING WILL TAKE PLACE DECEMBER 3, 2012.

The survey will take less than 10 minutes to complete and can be filled out online (link provided below); no personal information will collected about you. Your participation in this study is voluntary. If you have any questions, please contact Michael Knox at 720-935-3994 or Knox.Michael.W@gmail.com. This research has been approved by CSU's institutional review board. If you have any questions about your rights as a volunteer in this research, contact Janell Barker, Human Research Administrator, at 970-491-1655.

Here is a link to the survey: [SurveyLink]

Please fill out the survey for: [CustomData]

Thanks in advance for your participation!

Sincerely,

Michael Knox

Graduate Student

Department of Construction Management

Colorado State University

Knox.Michael.W@gmail.com

720-935-3994 


\section{Appendix G: E-Survey Email Recruitment Script- First Reminder}

Title: Reminder: LEED Research Study- Chance to Win a \$50 Amazon Gift Card

Dear [FirstName] [LastName],

Last week, you received a request to complete a survey seeking your feedback about the [CustomValue] in regard to the charrette process.

If you have already completed the online survey, please accept our sincere thanks. If not, please do so today. We are grateful for your help, and believe that your response will be very useful in moving the green building industry further!

AFTER COMPLETING THE SURVEY, YOU MAY CHOOSE TO ENTER TO WIN A \$50 AMAZON GIFT CARD. DRAWING WILL TAKE PLACE DECEMBER 3, 2012.

The survey will take less than 10 minutes to complete. If you have any questions, please write or call me at 720-935-3994.

Here is a link to the survey: [SurveyLink]

Please fill out the survey for: [CustomValue]

Sincerely,

Michael Knox

Graduate Student

Department of Construction Management

Colorado State University

Knox.Michael.W@gmail.com

720-935-3994 


\section{Appendix H: E-Survey Email Recruitment Script- Final Reminder}

Title: FINAL REMINDER: LEED Research Study- Chance to Win a \$50 Amazon Gift Card

Dear [FirstName] [LastName],

We have contacted you several times regarding the completion of a survey for the research project "Impact of Charrette Characteristics on Achieved LEED Certification."

While a good number of surveys have been returned, we still do not have enough to complete the research. Please complete your on-line survey before the Nov 1st deadline. We believe that your response will be very useful in moving the green building industry further.

AFTER COMPLETING THE SURVEY, YOU MAY CHOOSE TO ENTER TO WIN A \$50 AMAZON GIFT CARD. DRAWING WILL TAKE PLACE DECEMBER 3, 2012.

The survey will take less than 10 minutes to complete. If you have any questions, please write or call me at 720-935-3994.

Here is a link to the survey: [SurveyLink]

Please fill out the survey for: [CustomValue]

Thanks in advance for your participation! This will be your final reminder.

Sincerely,

Michael Knox

Graduate Student

Department of Construction Management

Colorado State University

Knox.Michael.W@gmail.com

720-935-3994 


\section{Appendix I: E-Survey Questions \& Consent}

\section{Consent}

TITLE OF STUDY: Investigating the Impact of Charrette Characteristics on Achieved LEED Certification

PRINCIPAL INVESTIGATOR: Caroline Clevenger, PhD, CSU Construction Management Dept., caroline.clevenger@colostate.edu

CO-PRINCIPAL INVESTIGATOR: Michael Knox, Graduate Student, CSU Construction Management Dept., Knox.Michael.W@gmail.com

WHAT IS THE PURPOSE OF THIS STUDY? The research will study the how certain design charrette characteristics impact the level of LEED certification a building project receives.

WHY AM I BEING INVITED TO TAKE PART IN THIS RESEARCH? If you are being asked to participate in the research, it is because you have been identified as the LEED project contact for a building project that has achieved LEED certification.

WHAT WILL I BE ASKED TO DO? You will be asked to participate in a survey that will last less than 10 minutes. You will be asked questions that relate to a LEED certified building project which was specified in an email sent to you.

WHAT ARE THE POSSIBLE RISKS AND DISCOMFORTS? There are no known risks to this research. However, it is not possible to identify all potential risks in research procedures, but the researcher(s) have taken reasonable safeguards to minimize any known and potential, but unknown, risks.

ARE THERE ANY BENEFITS FROM TAKING PART IN THIS STUDY? There are no direct benefits to participating in the research. However, at the completion of the survey you will have a chance to enter to win a $\$ 50$ dollar Amazon gift card.

DO I HAVE TO TAKE PART IN THE STUDY? Your participation in this research is voluntary. If you decide to participate in the study, you may withdraw your consent and stop participating at any time without penalty or loss of benefits to which you are otherwise entitled.

WHO WILL SEE THE INFORMATION THAT I GIVE? Your information will be combined with information from other people taking part in the study. No personal information will be linked to the data collected during the session. The data for this project will not be kept with any identifiable personal information. The researcher intends to publish the results of this study.

WHAT IF I HAVE QUESTIONS? If you have questions about the study, you can contact the investigator, Michael Knox at Knox.Michael.W@gmail.com. If you have any questions about your rights as a volunteer in this research, contact Janell Barker, Human Research Administrator at 970-491-1655.

Your participation in this survey acknowledges that you have read the information stated above

\section{*1. Are you willing to participate in this survey?}

Agree to Participate

Disagree to Participate 


\section{Building Project Type}

The questions in this survey are intended to be answered only about the building project that was specified in the email sent to you. This building project is referred to as "the building project in question" and it is important that you only answer questions based on this project and not other building projects that you may have worked on.

\section{Select the LEED project type that describes the building project in question, select all}

\section{that apply:}

$\square$ Animal Care

$\square$ Laboratory

Assembly

$\square$ Leisure

$\longrightarrow$ Campus

$\square$ Library

Commercial Office

$\square$ Military Base

Community Development

$\square$ Multi-Unit Residence

Daycare

$\square$ Parks and Public Spaces

Entertainment

$\square$ Public Order and Safety

Financial

$\square$ Recreation

$\longrightarrow$ Government

$\square$ Religious

Healthcare

$\square$ Restaurant

$\square$ Higher Education

$\square$ Retail

$\longrightarrow$ Hotel/Resort

$\square$ Special Needs

Industrial

$\square$ Stadium/Arena

Interpretive Center

$\square$ Transportation

K-12 Education

Other (please specify)

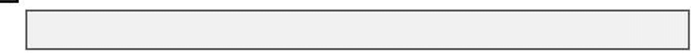




\section{LEED Outcomes}

The questions in this survey are intended to be answered only about the building project that was specified in the email sent to you. This building project is referred to as "the building project in question" and it is important that you only answer questions based on this project and not other building projects that you may have worked on.

*3. How many LEED points were received for the building project in question? (Project points mentioned in email.)

LEED Points:

4. What level of LEED Certification did the building project in question receive?
Certified (40-49 points)
Silver (50-59 points)
Gold (60-79 points)
Platinum (80+ points)

*5. A design charrette is an intensively focused, interdisciplinary, collaborative work session where participants design and problem solve in consensus (Lennertz, et al.., 2006; Lindsey, et al., 2009; Watson \& American Institute of Architects, 1996).

Was one or more design charrettes conducted for this building project?

Y Yes

No 


\section{Integrated or Traditional Delivery/Design}

Read the definitions below and then answer the question:

Integrated Project Delivery/Design: "a project delivery approach that integrates people, systems, business structures and practices into a process that collaboratively harnesses the talents and insights of all participants to reduce waste and optimize efficiency through all phases of design, fabrication and construction" (AIA California Council, 2007).

Traditional Process: a design process that does not include the use of charrettes or similar integrated delivery/design processes.

\section{What type of delivery/design process was used for the building project in question?}

Integrated Project Delivery/Design Process

Traditional Design Process 


\section{Traditional Design Process}

Read the definitions below and then answer the question:

Integrated Project Delivery/Design: "a project delivery approach that integrates people, systems, business structures and practices into a process that collaboratively harnesses the talents and insights of all participants to reduce waste and optimize efficiency through all phases of design, fabrication and construction" (AIA California Council, 2007).

Traditional Process: a design process that does not include the use of charrettes or similar integrated delivery/design processes.

\section{For the following questions, identify the degree to which you agree or disagree with} each statement given.

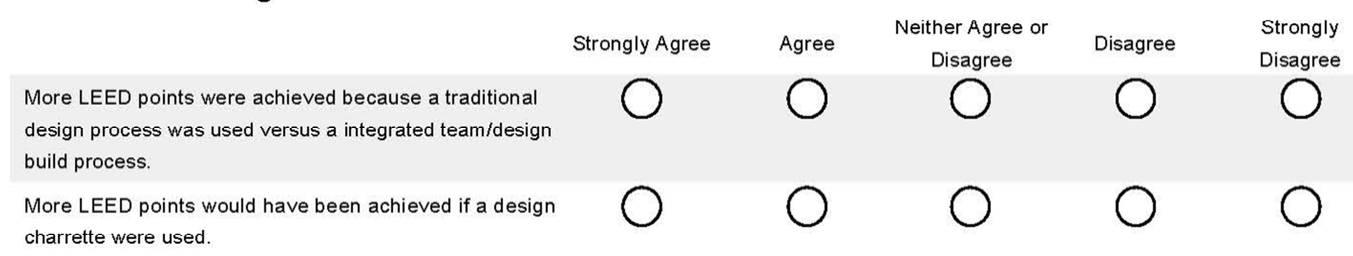

\section{In your opinion, why was a design charrette NOT conducted as part of the design} process for the building project in question?

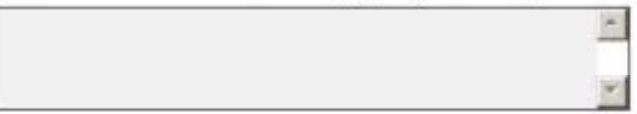

Please complete the survey by selecting "Done/Next" at the bottom of the page. You will automatically be redirected to a separate page where you may ehoose to enter the $\$ 50$ Amazon gir card drawing. Data collected from this survey will be stored separate from any contact information collected for the drawing.

If you are not automatically redirected after you click finish and would still like to enter the drawing please email your request to:

knox.michael.w@gmail.com 


\section{No Charrette Conducted}

Integrated Project Delivery/Design: "a project delivery approach that integrates people, systems, business structures and practices into a process that collaboratively harnesses the talents and insights of all participants to reduce waste and optimize efficiency through all phases of design, fabrication and construction" (AIA California Council, 2007).

Traditional Process: a design process that does not include the use of charrettes or similar integrated delivery/design processes.

\section{What characteristics were TYPICAL of the underlying integrated team/design-build meetings for the building project in question? Select all that apply:}

Meetings focused on specific aspect of the building project
Meetings had few participants ( $<10$ people)
Meetings were used to educate the participants about the building project
Meetings addressed high level problems/challenges
Rotating breakout group sessions were used during the meetings
Project stakeholders participated as necessary throughout the meetings
Meetings provided valuable time to communicate with owners or owner representatives
Meetings were used to produced high level innovation, development, creativity and inspiration
Project goals were already defined before the meetings took place
Meetings included interdisciplinary or specialty participants (students, community, etc.)
Meetings had a defined/structured agenda
Meetings included project brainstorming
Meetings were held as part of a series of meetings
Meetings were held as a LEED strategy/LEED checklist meeting

10. For the following questions, identify the degree to which you agree or disagree with each statement given.

\begin{tabular}{|c|c|c|c|c|c|}
\hline & Strongly Agree & Agree & $\begin{array}{c}\text { Neither Agree or } \\
\text { Disagree }\end{array}$ & Disagree & $\begin{array}{l}\text { Strongly } \\
\text { Disagree }\end{array}$ \\
\hline $\begin{array}{l}\text { More LEED points were achieved because a integrated } \\
\text { design process was used versus a traditional design } \\
\text { process. }\end{array}$ & & & & & \\
\hline
\end{tabular}

11. In your opinion, why was a design charrette NOT conducted as part of the design process for the building project in question? 
Please complete the survey by selecting "Done/Next" at the bottom of the page. You will automatically be redirected to a separate page where you may choose to enter the $\$ 50$ Amazon gift card drawing. Data collected from this survey will be stored separate from any contact information collected for the drawing

If you are not automatically redirected after you click finish and would still like to enter the drawing please email your request to: knox.michael.w@gmail.com 


\section{Short Charrettes?}

A design charrette is an intensively focused, interdisciplinary, collaborative work session where participants design and problem solve in consensus (Lennertz, et al., 2006; Lindsey, et al., 2009; Watson \& American Institute of Architects, 1996).

For the purposes of this survey, design charrettes will be distinguished by the following lengths:

Short Design Charrette: $\geq 2$ to $\leq 4$ Hours

Long Design Charrette: $>4$ Hours

* 12. Was one or more SHORT Design Charrettes ( $\geq 2$ to $\leq 4$ Hours) conducted on this building project?

Ores

Ono 


\section{Short Charrette Characteristics}

A design charrette is an intensively focused, interdisciplinary, collaborative work session where participants design and problem solve in consensus (Lennertz, et al., 2006; Lindsey, et al., 2009; Watson \& American Institute of Architects, 1996).

For the purposes of this survey, design charrettes will be distinguished by the following lengths:

Short Design Charrette: $\geq 2$ to $\leq 4$ Hours

Long Design Charrette: $>4$ Hours

13. Select how many SHORT Design Charrettes ( $\geq 2$ to $\leq 4$ Hours) were conducted and at which phase of the design process for the building project in question. Select " 0 " for phase in which no charrette was conducted.

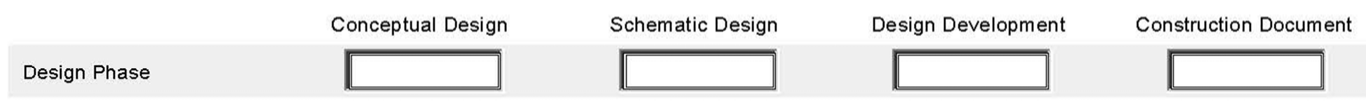

\section{Please check all characteristics that were TYPICAL of the SHORT Design Charrettes} ( $\geq 2$ to $\leq 4$ Hours) that were conducted for the building project in question.

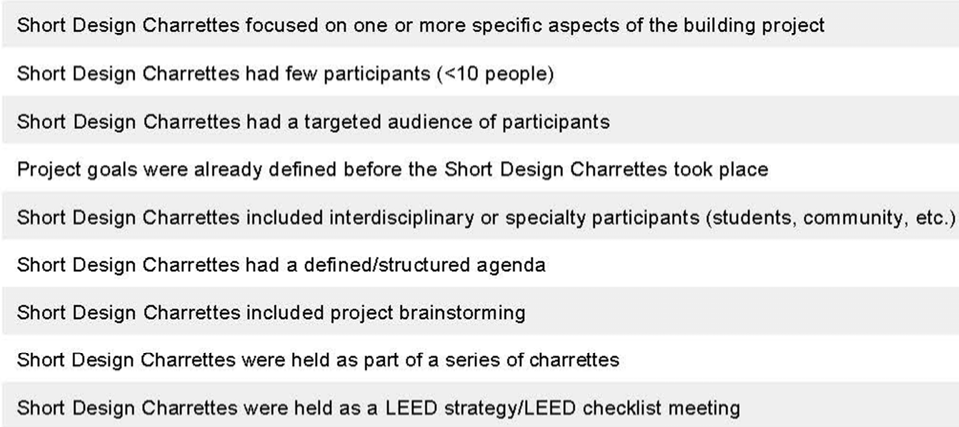

Characteristic Typical

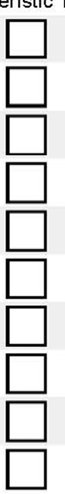




\section{Please check individuals that participated in one or more SHORT Design Charrettes $(\geq 2$} to $\leq 4$ Hours) for the building project in question.

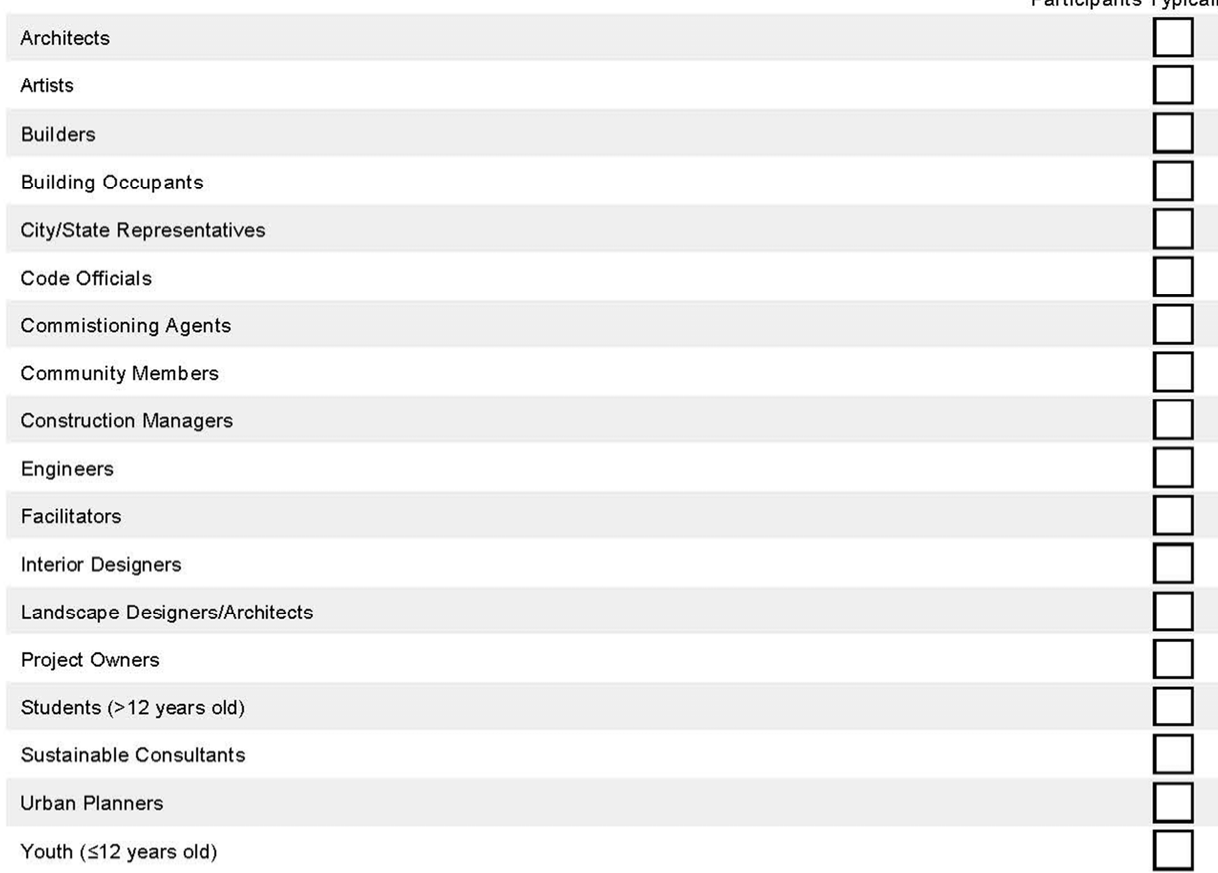

16. Identify outcomes of the building project where SHORT Design Charrettes ( $\geq 2$ to $\leq 4$ Hours) where performed. Check all that apply.

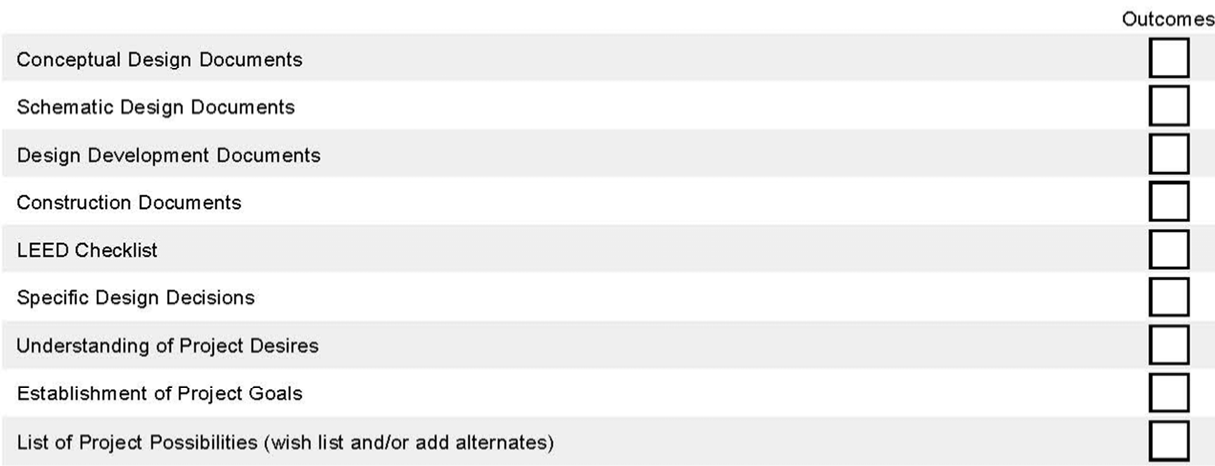




\section{Long Charrettes?}

A design charrette is an intensively focused, interdisciplinary, collaborative work session where participants design and problem solve in consensus (Lennertz, et al., 2006; Lindsey, et al., 2009; Watson \& American Institute of Architects, 1996).

For the purposes of this survey, design charrettes will be distinguished by the following lengths:

Short Design Charrette: $\geq 2$ to $\leq 4$ Hours

Long Design Charrette: $>4$ Hours

* 17. Was one or more LONG Design Charrettes (>4 Hours) conducted on this building project?

OYES

No 


\section{Long Charrette Characteristics}

A design charrette is an intensively focused, interdisciplinary, collaborative work session where participants design and problem solve in consensus (Lennertz, et al., 2006; Lindsey, et al., 2009; Watson \& American Institute of Architects, 1996).

For the purposes of this survey, design charrettes will be distinguished by the following lengths:

Short Design Charrette: $\geq 2$ to $\leq 4$ Hours

Long Design Charrette: $>4$ Hours

18. Select how many LONG Design Charrettes (>4 Hours) were conducted and at which phase of the design process for the building project in question.

Conceptual Design

Schematic Design

Design Development

Construction Document

Design Phase
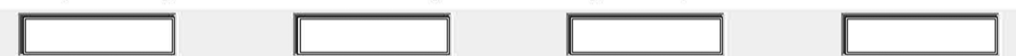

19. Please check all characteristics that were TYPICAL of the LONG Design Charrettes (>4 Hours) that were conducted for the building project in question.

Long Design Charrettes were used to educate the participants about the building project
Long Design Charrettes addressed high level problems/challenges
Rotating breakout group sessions were used during the Long Design Charrettes
Project stakeholders participated as necessary throughout Long Design Charrettes
Long Design Charrettes provided valuable time to communicate with owners or owner representatives
Long Design Charrettes were used to produced high level innovation, development, creativity and
inspiration
Project goals were already defined before the Long Design Charrettes took place
Long Design Charrettes included interdisciplinary or specialty participants (students, community, etc.)
Long Design Charrettes had a defined/structured agenda
Long Design Charrettes included project brainstorming
Long Design Charrettes were held as part of a series of charrettes
Long Design Charrettes were held as a LEED strategy/LEED checklist meeting
A Long Design Charrette was used to "Kickoff' the building project




\section{Please check individuals that participated in one or more LONG Design Charrettes (>4} Hours) for the building project in question.

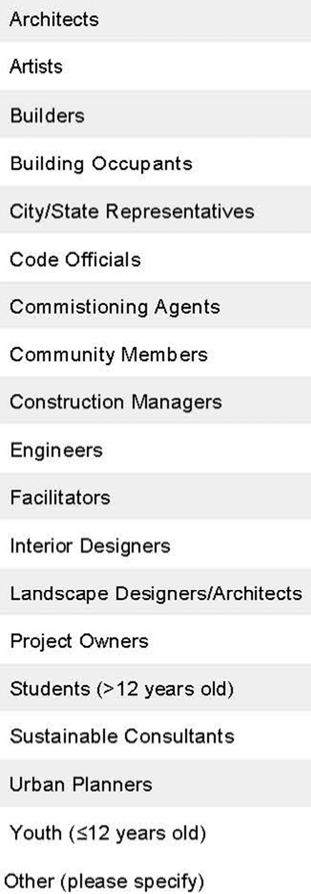
where performed. Check all that apply.

Conceptual Design Documents

Schematic Design Documents

Participants Typically Involved

Design Development Documents

Construction Documents

LEED Checklist

Specific Design Decisions

Understanding of Project Desires

Establishment of Project Goals

List of Project Possibilities (wish list and/or add alternates)

Other (please specify) 


\section{Charrette Follow-up Questions}

Below are examples of networks with connections betwe en participants. Each line represents a previous personal connection between two people.

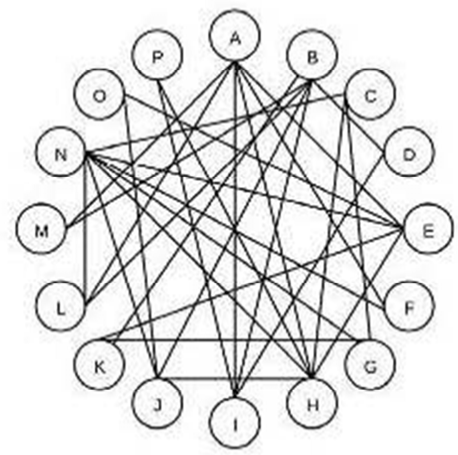

Many Connections

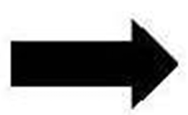

22. We re charrette participants highly networked (having many personal connections) or not very networke (having few personal connections) at the BEGINNING of the charrette process? Please rate the level of connections:

Many Conections

Some Connections

Fen Connections

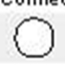

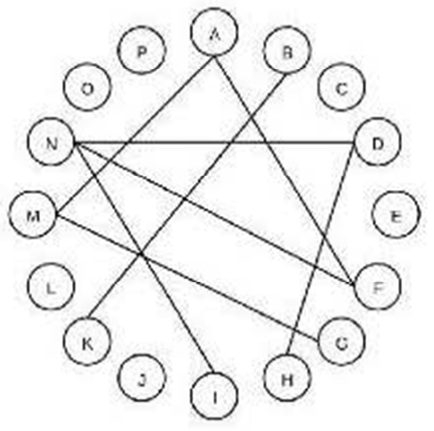

Few Connections

23. We re charrette participants highly networked (having many personal connections) or not very networke d (having few personal connections) at the END of the charrette process? Please rate the level of connections:

Many Conections

Some Connection

$\mathrm{F}$ en Connections<smiles>c1ccccc1</smiles>

Very Few $C$ onnections

()
No Connections

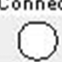

Don't Knaw

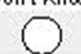



24. For the following questions, identify the degree to which you agree or disagree with each statement given.

The design charrette(s) were an important part of the
project's LEED certification.
A higher level of sustainability was achieved because
design charrettes were conducted.
More LEED points were achieved because design
charrettes were conducted.
More LEED points would have been achieved if ONLY
the traditional design process was used.
If more design charrettes had been implemented, the
project may have attained more LEED points.
If a higher quality design charrette was implemented,
more LEED points could have been attained.

25. In your opinion, what were the benefits to conducting design charrette(s) during the design of the building project in question?

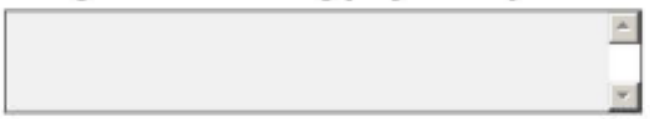

26. In your opinion, what were the challenges/ problems in conducting design charrette(s) during the design of the building project in question, if any?

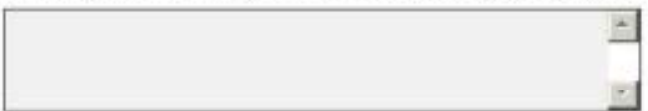

27. Do you have any suggestions for conducting successful design charrettes focused on producing LEED certified buildings?

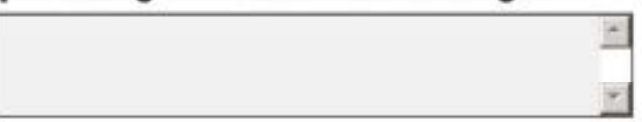

Please complete the survey by selecting "Done/Next" at the bottom of the page. You will automatically be redirected to a separate page where you may choose to enter the $\$ 50$ Amazon gin card drawing. Data collected from this survey will be stored separate from any contact information collected for the drawing.

If you are not automatically redirected after you click finish and would still like to enter the drawing please email your request to:

knox.michael.w@gmail.com 


\section{$\$ 50$ Amazon Gift Card}

Thank you for participating in this research project!

To enter the drawing or to sign up to receive the final results by email, please fill out the form below. This information will NOT be linked to your survey. All survey results will remain completely anonymous.

If you do not wish to enter your contact information, click "Exit" in the upper right hand corner.

1. To be entered to win a $\$ 50$ Amazon gift card, please enter your email below. The drawing will occur December 3, winner will be notified by email.

2. If you would like final results sent to you once the research is completed, please enter your email below. 


\section{Appendix J: Coding of E-Survey Instrument}

1. Are you willing to participate in this survey?

Agree to participate $=1$

Disagree to participate $=2$

2. Select the LEED project type that describes the building project in question, select all that apply:

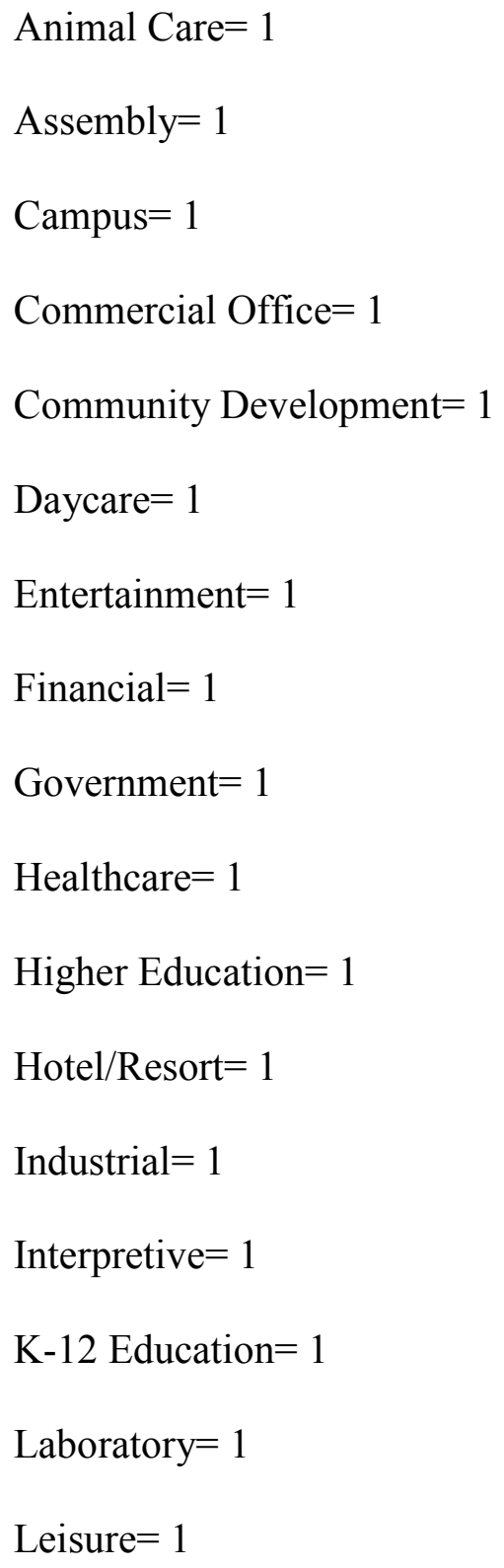




$$
\begin{aligned}
& \text { Library }=1 \\
& \text { Military Base }=1 \\
& \text { Multi-unit Residence }=1 \\
& \text { Parks and Open Spaces }=1 \\
& \text { Public Order and Safety=1 } \\
& \text { Recreation=1 } \\
& \text { Religious }=1 \\
& \text { Restaurant }=1 \\
& \text { Retail=1 } \\
& \text { Special Needs }=1 \\
& \text { Stadium } / \text { Arena }=1 \\
& \text { Transportation }=1 \\
& \text { Other }=1
\end{aligned}
$$

3. How many LEED points were received for the building project in question?

4. How many LEED points were received for the building project in question receive?

$$
\begin{aligned}
& \text { Certified }(40-49 \text { points })=1 \\
& \text { Silver }(50-59 \text { points })=2 \\
& \text { Gold }(60-79 \text { points })=3 \\
& \text { Platinum }(80+)=4
\end{aligned}
$$

5. Was one or more design charrettes conducted for this building project?

$$
\begin{aligned}
& \mathrm{Yes}=1 \\
& \mathrm{No}=0
\end{aligned}
$$

6. What type of delivery/design process was used for the building project in question? 


\section{Integrated Project Delivery/Design Process $=1$ \\ Traditional Design Process $=2$}

7. For the following questions, identify the degree to which you agree or disagree with each statement given.

7.1. More LEED points were achieved because a traditional design process was used versus a integrated team/design build process.

Strongly agree $=1$

Agree $=2$

Neither Agree or Disagree $=3$

Disagree $=4$

Strongly Disagree $=5$

7.2. More LEED points would have been achieved if a design charrette were used.

Strongly agree $=1$

Agree $=2$

Neither Agree or Disagree= 3

Disagree $=4$

Strongly Disagree $=5$

8. In your opinion, why was a design charrette NOT conducted as part of the design process for the building project in question?

9. What characteristics were TYPICAL of the underlying integrated team/design-build meetings for the building project in question? Select all that apply:

Specific Aspect $=1$

Few Participants $=1$ 


$$
\begin{aligned}
& \text { Education }=1 \\
& \text { High Level=1 } \\
& \text { Breakout }=1 \\
& \text { Stakeholders=1 } \\
& \text { Communicate=1 } \\
& \text { Innovation=1 } \\
& \text { Goals=1 } \\
& \text { Interdisciplinary=1 } \\
& \text { Defined/Structured=1 } \\
& \text { Brainstorming=1 } \\
& \text { Charrette Series=1 } \\
& \text { Strategy/Checklist=1 }
\end{aligned}
$$

10. For the following questions, identify the degree to which you agree or disagree with each statement given.

10.1. More LEED points were achieved because a integrated design process was used versus a traditional design process

Strongly agree $=1$

Agree $=2$

Neither Agree or Disagree $=3$

Disagree $=4$

Strongly Disagree $=5$

10.2. More LEED points would have been achieved if a design charrette were used. Strongly agree $=1$ 


$$
\text { Agree }=2
$$

Neither Agree or Disagree $=3$

Disagree $=4$

\section{Strongly Disagree $=5$}

11. In your opinion, why was a design charrette not conducted as part of the design process for the building project in question?

12. Was one or more Short Design Charrette ( $\geq 2$ to $\leq 4$ Hours) conducted on this building project?

$$
\begin{aligned}
& \text { Yes }=1 \\
& \mathrm{No}=0
\end{aligned}
$$

13. Select how many Short Design Charrettes ( $\geq 2$ to $\leq 4$ Hours) were conducted and at which phase of the design process for the building project in question.

13.1. Conceptual Design= $1-6$

13.2. Schematic Design $=1-6$

13.3. Design Development $=1-6$

13.4. Construction Document $=1-6$

14. Please check all characteristics that were typical of the Short Design Charrettes $(\geq 2$ to $\leq 4$ Hours) that were conducted for the building project in question.

$$
\begin{aligned}
& \text { Specific Aspect=1 } \\
& \text { Few Participants=1 } \\
& \text { Targeted }=1 \\
& \text { Goals }=1 \\
& \text { Interdisciplinary }=1
\end{aligned}
$$



Defined/Structured $=1$
Brainstorming $=1$
Charrette Series $=1$
Strategy/Checklist $=1$
Kickoff $=1$

15. Please check individuals that participated in one or more Short Design Charrettes $(\geq 2$ to $\leq 4$ Hours) for the building project in question.
Architects $=1$
Artists $=1$
Builders $=1$
Building Occupants $=1$
City/State Representatives $=1$
Code Officials $=1$
Commissioning Agents $=1$
Community Members= 1
Construction Managers $=1$
Engineers $=1$
Facilitators $=1$
Interior Designers $=1$
Landscape Designers $=1$
Project Owners $=1$
Students $(>12$ years old $)=1$
Sustainable Consultants $=1$ 


$$
\begin{aligned}
& \text { Urban Planners }=1 \\
& \text { Youth }(\leq 12 \text { years old })=1 \\
& \text { Other }=1
\end{aligned}
$$

16. Identify outcomes of the building project were Short Design Charrettes ( $\geq 2$ to $\leq 4$ Hours) where performed. Check all that apply

$$
\begin{aligned}
& \text { Conceptual Design Docs }=1 \\
& \text { Schematic Design Docs }=1 \\
& \text { Design Development Docs }=1 \\
& \text { Construction Documents }=1 \\
& \text { LEED Checklist }=1 \\
& \text { Specific Design Decisions }=1 \\
& \text { Understanding Project Desires }=1 \\
& \text { Establishment of Project Goals }=1 \\
& \text { List of Project Possibilities }=1 \\
& \text { Other=1 }
\end{aligned}
$$

17. Was one or more Long Design Charrettes ( $>4$ Hours) conducted on this building project?

$$
\begin{aligned}
& \text { Yes }=1 \\
& \mathrm{No}=0
\end{aligned}
$$

18. Select how many Long Design Charrettes ( $>4$ Hours) were conducted and at which phase of the design process for the building project in question.

18.1. Conceptual Design=1-6

18.2. Schematic Design $=1-6$

18.3. Design Development $=1-6$ 
18.4. Construction Document $=1-6$

19. Please check all characteristics that were typical of the Long Design Charrettes ( $>4$ Hours) that were conducted for the building project in question.

$$
\begin{aligned}
& \text { Education }=1 \\
& \text { High Level=1 } \\
& \text { Breakout }=1 \\
& \text { Stakeholders=1 } \\
& \text { Communicate=1 } \\
& \text { Innovation=1 } \\
& \text { Goal =1 } \\
& \text { Interdisciplinary=1 } \\
& \text { Defined/Structured=1 } \\
& \text { Brainstorming=1 } \\
& \text { Charrette Series=1 } \\
& \text { Strategy/Checklist=1 } \\
& \text { Kickoff=1 }
\end{aligned}
$$

20. Please check individuals that participated in one or more Long Design Charrettes ( $>4$ Hours) for the building project in question.

$$
\begin{aligned}
& \text { Architects }=1 \\
& \text { Artists }=1 \\
& \text { Builders }=1 \\
& \text { Building Occupants }=1 \\
& \text { City/State Representatives }=1
\end{aligned}
$$


Code Officials $=1$

Commissioning Agents $=1$

Community Members= 1

Construction Managers $=1$

Engineers $=1$

Facilitators $=1$

Interior Designers $=1$

Landscape Designers $=1$

Project Owners $=1$

Students $(>12$ years old $)=1$

Sustainable Consultants $=1$

Urban Planners $=1$

Youth $(\leq 12$ years old $)=1$

Other $=1$

21. Identify outcomes of the building project were Long Design Charrettes ( $>4$ Hours) were performed Check all that apply.

Conceptual Design Docs $=1$

Schematic Design Docs $=1$

Design Development Docs $=1$

Construction Documents $=1$

LEED Checklist= 1

Specific Design Decisions $=1$

Understanding Project Desires $=1$ 
Establishment of Project Goals $=1$

List of Project Possibilities $=1$

Other $=1$

22. Were charrette participants highly networked (having many personal connections) or not very networked (having few personal connections) at the beginning of the charrette process. Please rate the level of connections:

$$
\begin{aligned}
& \text { Many Connections }=1 \\
& \text { Some Connections }=2 \\
& \text { Few Connections }=3 \\
& \text { Very Few Connections }=4 \\
& \text { No Connections }=5 \\
& \text { Don't Know }=6
\end{aligned}
$$

23. Were charrette participants highly networked (having many personal connections) or not very networked (having few personal connections) at the end of the charrette process. Please rate the level of connections:

$$
\begin{aligned}
& \text { Many Connections }=1 \\
& \text { Some Connections }=2 \\
& \text { Few Connections }=3 \\
& \text { Very Few Connections }=4 \\
& \text { No Connections }=5 \\
& \text { Don't Know }=6
\end{aligned}
$$

24. For each of the following questions, identify the degree to which you agree or disagree with each statement given. 
24.1. The design charrettes(s) were an important part of the projects LEED certification.

$$
\begin{aligned}
& \text { Many Connections }=1 \\
& \text { Some Connections }=2 \\
& \text { Few Connections }=3 \\
& \text { Very Few Connections= } 4 \\
& \text { No Connections }=5 \\
& \text { Don't Know }=6
\end{aligned}
$$

24.2. A higher level of sustainability was achieved because design charrettes were conducted.

$$
\begin{aligned}
& \text { Many Connections }=1 \\
& \text { Some Connections }=2 \\
& \text { Few Connections }=3 \\
& \text { Very Few Connections= } 4 \\
& \text { No Connections }=5 \\
& \text { Don't Know }=6
\end{aligned}
$$

24.3. More LEED points were achieved because design charrettes were conducted.

$$
\begin{aligned}
& \text { Many Connections }=1 \\
& \text { Some Connections }=2 \\
& \text { Few Connections= } 3 \\
& \text { Very Few Connections= } 4 \\
& \text { No Connections }=5 \\
& \text { Don't Know }=6
\end{aligned}
$$

24.4. More LEED points would have been achieved if only the traditional design process was used. 
Many Connections $=1$

Some Connections $=2$

Few Connections $=3$

Very Few Connections $=4$

No Connections $=5$

Don't Know $=6$

24.5. If more design charrettes had been implanted, the project may have attained more LEED points.
Many Connections $=1$
Some Connections $=2$
Few Connections $=3$
Very Few Connections $=4$
No Connections $=5$
Don't Know $=6$

24.6. If a higher quality design charrette was implemented, more LEED points could have been attained.

Many Connections $=1$

Some Connections $=2$

Few Connections $=3$

Very Few Connections $=4$

No Connections $=5$

Don't Know $=6$ 
25. In your opinion, what were the benefits to conducting design charrette(s) during the design of the building project in question?

26. In your opinion, what were the challenges/problems in conducting design charrette(s) during the design of the building project in question?

27. Do you have any suggestions for conducting successful design charrettes focused on producing LEED certified buildings? 
Appendix K: Quantitative E-Survey Responses 


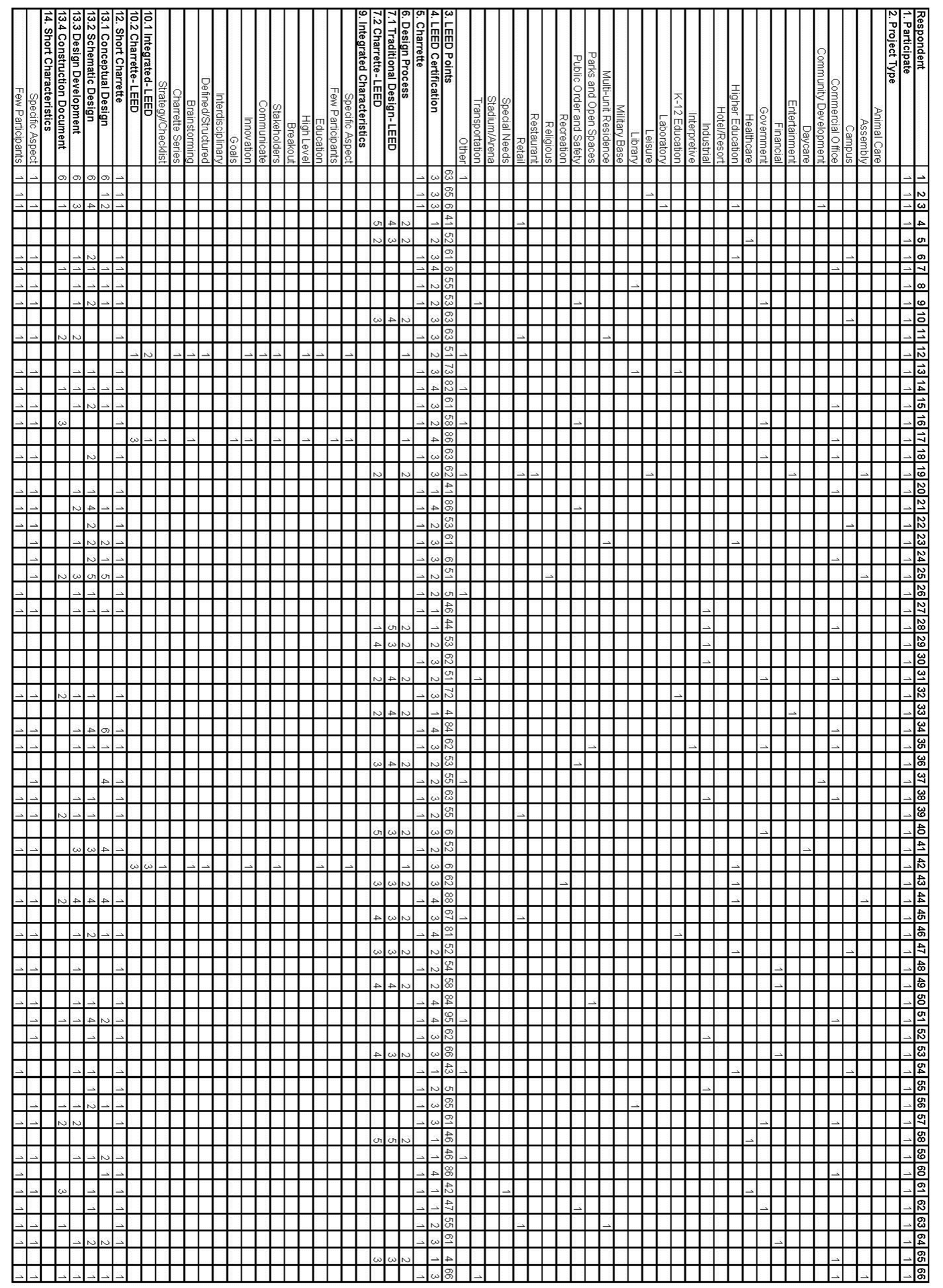




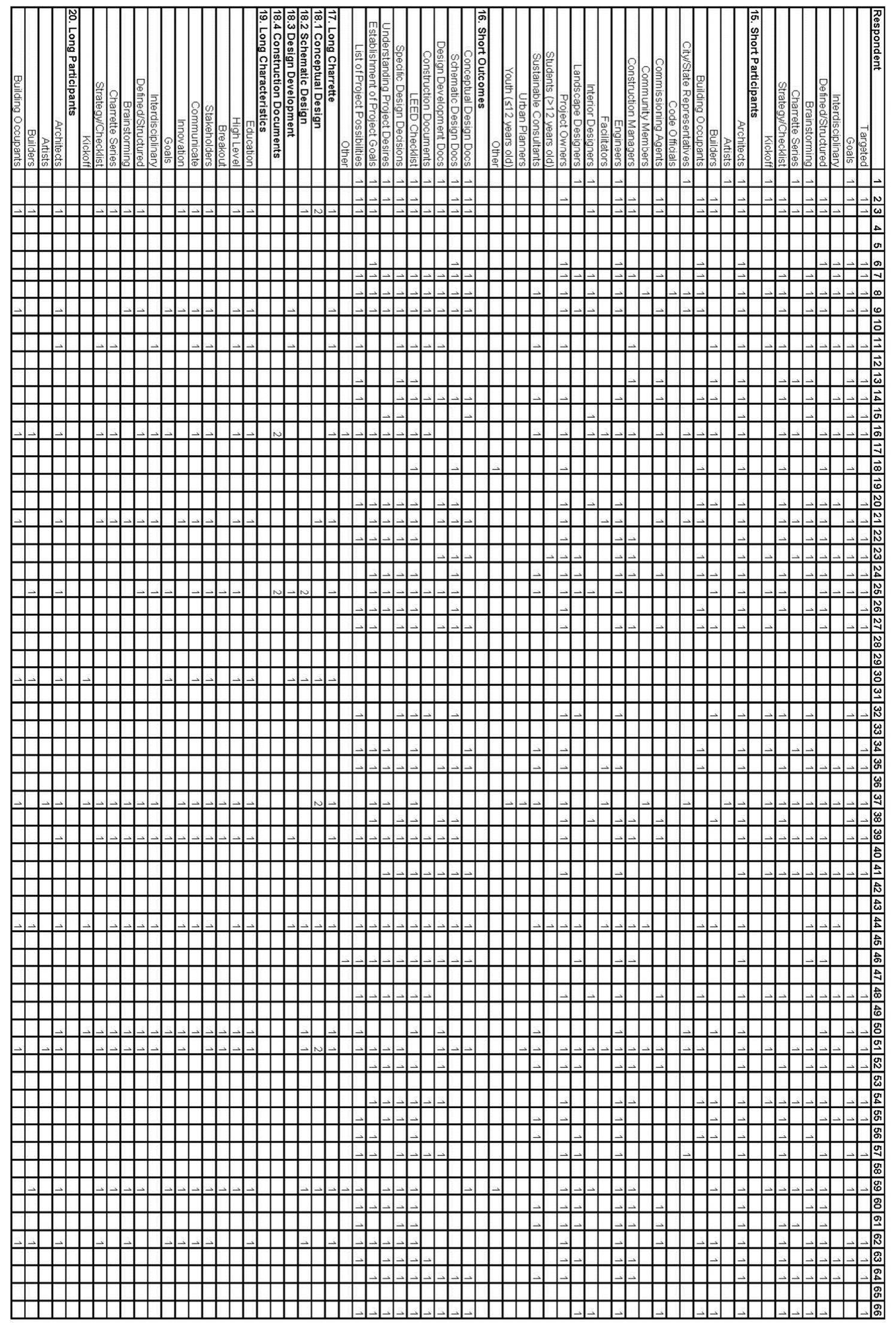




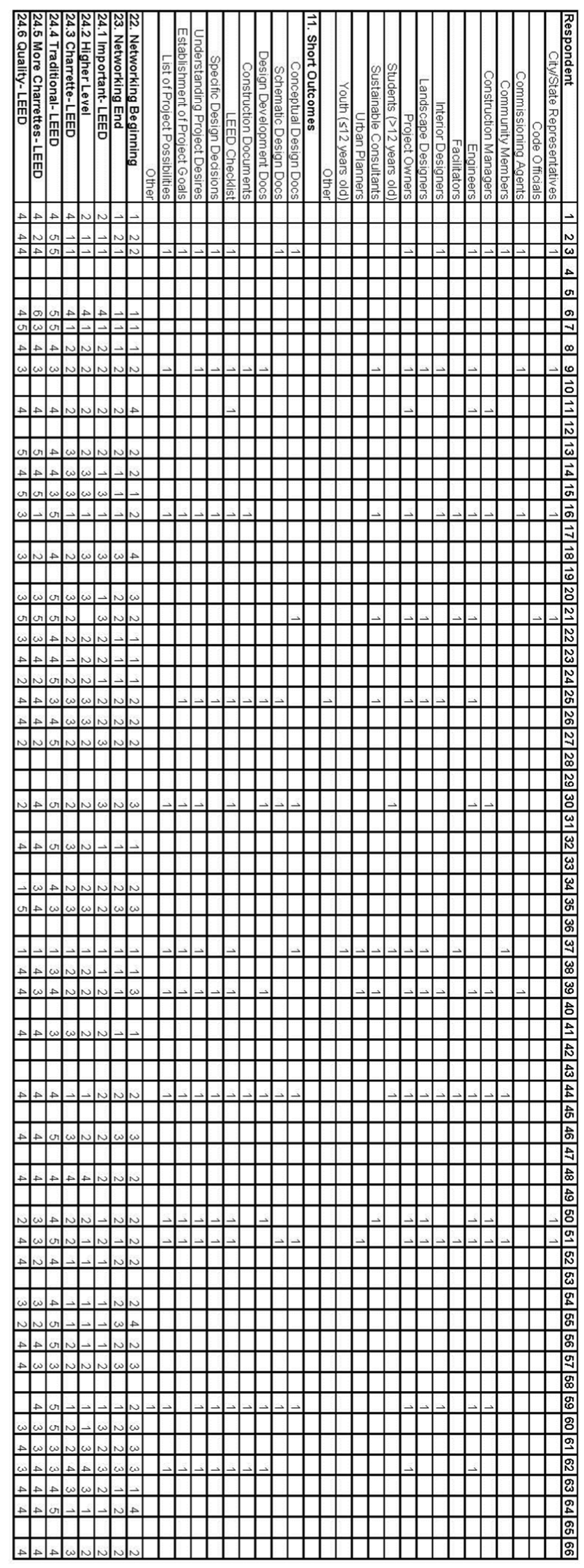




\section{Appendix L: Qualitative E-Survey Responses}

Question 8: In your opinion, why was a design charrette NOT conducted as part of the design process for the building project in question?

1. This project was quite similar to another project for this client. The previous project design decisions were carefully studied.

2. The building is based on a prototype design used by the client throughout the country

3. The project was the adaptation of a standard prototype and therefore most information was already defined. The architect took this information and site adapted it with LEED in mind as well as the site constraints.

4. Process typical with client (state university).

5. The decision to seek LEED certification was made AFTER the building was designed

6. Our firm practices with a traditional design process.

7. The floor plan for this project was actually a prototype plan that was used for several different [projects]. With the plan established, the focus was on appropriate siting the building and on design of the facades utilizing regional influences.

8. Inexperience of project team, lack of interest of owner/operator and lack of design fee for protracted design process. LEED Silver was a government requirement for project and there was little incentive to make this an innovative project.

9. All members of the team were from different areas/states. It would have been difficult to assemble everyone together at the same time.

10. Owner was not educated about the process. General inertia towards using traditional methods on smaller projects 
11. Owner had little interest in the design process or understanding of LEED principles in general. As the design builder, we really relied heavily on the architect and engineers to design a facility where we would be able to achieve LEED certification.

12. The project moved very quickly and decisions were made before a charrette could be conducted. Also, not all players were involved early in the process.

13. Decision to pursue LEED occurred too late in the project and the level of Certification was not set until after schematic design.

14. Charrettes are not a part of the design process at [firm].

15. Simply did not have the time. We were behind schedule due to budget and change in scope.

16. The simplicity of building program does not necessitate a charrette. Compressed project scheduling also did not allow for it.

Question 11: In your opinion, why was a design charrette NOT conducted as part of the design process for the building project in question?

1. Not enough time

2. We were already a interdisciplinary and integrated team working on the project - we chose the route of several short meetings instead of a 3-7 day intensive charrette. Mostly do to time and commitment factors of the stakeholders involved.

3. CM at risk project delivery method--this firm is not used to charrettes and does not devote a lot of additional effort at the design level. Good meetings throughout project however 
Question 25: In your opinion, what were the benefits to conducting design charrette(s) during the design of the building project in question?

1. Improved goal setting and establishing consensus on which aspects were most important.

2. Goal establishment, buy-in on approaches, technologies and strategies, confirmation of details and costs.

3. Brainstorming solutions

4. Each participant could offer their input based on their expertise so strategies could be pursued or discounted immediately

5. Tremendous time saver. Direct communication led to immediate weighing of options and faster decisions. Instantaneous interaction of all participants led to more focused and valuable input and immediate answers to questions. Allowed for rapid review of many more alternative schemes or design solutions. Always produced a superior and better functioning solution.

6. Establish project goals and targeted LEED points

7. They encourage communication and collaboration between team members and often result in more thorough, integrated designs.

8. Quicker solutions. Goals and objectives were defined real well.

9. Setting project vision, brainstorming new ideas

10. A chance for the team to connect and communicate.

11. To make sure everyone knew what the goals were and what their role was in achieving them.

12. Stronger implementation of sustainable design strategies

13. Integrated process/integrated design 
14. Accountability through communication improved quality.

15. Ensuring that all team members we focusing on the same project goals.

16. Client gained an understanding of environmental and sustainable design goals and concepts.

17. Incorporating sustainable design as early as possible at a time when nothing is set in stone allows access to more LEED credits.

18. My experience has been that using a charrette to engage a team during design is the most effective way to address complex problems. This is regardless of a goal of LEED/sustainability or not. We feel that well-designed, good projects employ charrette thinking to achieve team member buy-in.

19. The building owner and the owner's staff were from Europe. Therefore, the design charrette was critical to bridging the cultural divide to better understand the design desires of the building owner.

20. The most important benefit is having the owner and the designers in the same room at the same time to discuss design options and get immediate feedback.

21. getting everyone on the same page and hearing all of the goals

22. More collaboration, more ideas.

23. Making sure members of the design team considered sustainable options.

24. Input from many perspectives. Able to achieve buy-in and consensus from the group

25. The primary benefit was to make clear to the Owner what choices would need to be made, and their accompanying costs, to achieve a certain level of certification 
26. The focus charrettes were better. Identifying opportunities that we already knew worked from an operational perspective was key, instead of coming up with a world of possibilities most of which would not apply

27. Aligned LEED goals with projected building costs

28. Establishing the sustainable strategies to be employed based on the LEED Checklist.

29. While the design charrette(s) were conducted during the Construction Documentation phase, at least the project was able to achieve Silver LEED certification, which was required to obtain the A.R.R.A. grant. Had this requirement not been mentioned to the project team until the project was under construction, the project would have never achieved LEED certification and the Owner/Occupant would not have received the majority of the project funding.

30. Gave the designer the opportunity to extract the concerns and desires of the owner.

31. Kept building owner and building occupants informed about the LEED certification processes.

32. Target points were achievable, not just targets.

33. I see the benefits as being primarily educational (for the client, engineers, contractors, etc). Having the owner in the room reinforcing the project/LEED goals in front of the engineers and GC was vital to the success of the project as it was very clear that the decisions were top down.

34. To establish the direction and goals of the project.

35. The biggest benefit is that all disciplines are at the table at one time and that most decisions can be made on the spot.

36. Team approach to problem solving. 
37. The charrettes utilized on this project focused primarily on the design challenges of repurposing the existing structure and the aesthetic impacts of building additions.

38. Early coordination between engineers and architect allowed for many LEED principle to be incorporated into the design of the project.

39. Establishing the sustainability goals prior to beginning design lead to fully integrated solutions.

40. The design team established a unified goal that we were then able to communicate, or present to the town.

Question 26: In your opinion, what were the challenges/ problems in conducting design charrette(s) during the design of the building project in question, if any?

1. Schedule coordination, timing with deliverable timeline, decision making follow up by owner.

2. Charrette held late in process

3. Getting all participants to allocate the time and asking owner to pay for all professionals time.

4. Keeping all participants focused on the question or solution at hand. Getting honest opinions or comments from all participants.

5. Cost feedback for each point is critical in determining which points are obtainable and which are not realistic.

6. Many team members are already overworked and hesitant to agree to long collaborative sessions.

7. No problems, requires the team to focus.

8. None 
9. Some factors might still be outstanding.

10. Educating the owner who had never done a LEED project what LEED is and what are the benefits. Educating participants in the processes and requirements for achieving and documenting points.

11. Architects and engineers should guard against 'falling in love' with a specific technologies without vetting proven performance or increased issues of building integration costs.

12. Education about holistic sustainability beyond LEED

13. Schedules synchronization

14. No problems

15. Our challenge was that the project in question was our own offices, and between schematic design and construction documents our company tripled in size. The charrettes conducted to design for 15 people were negated. They had to be redone with new goals for 30 then 40 people.

16. Scheduling very talented, very busy individuals to participate. Documenting the outcome to ensure that each team member knows what their expectations for deliverables are.

17. Covering the language barrier cultural differences and expectations with the European owners.

18. A tight budget with the owner asking what are the cost implications for each design idea.

19. Lack of detailed technical information by owner

20. Getting everyone involved, keeping everyone involved

21. Members of the design team sticking with pre-conceived concepts and reluctant to consider options. 
22. Goals for level of LEED certification changed (increased) as the project advanced.

23. Project was design-build; Owner's desire for a certain certification level had cost impacts that were borne by the $\mathrm{CM}$-at-risk

24. Focused, discipline specifies charrettes worked best for this project since everything had to work with the emergency operations criteria or the station

25. Providing costs for specific LEED aspects of design during early phases of the design

26. Given the physical locations of the team, most of this work was done primarily over the phone.

27. The project was $100 \%$ designed, budgeted, and bid BEFORE the Owner received an A.R.R.A. grant, in which they were required to seek LEED certification. The challenge was the project was not seeking LEED certification initially, or prior to the completion of the Construction Documents being completed and the project being bid out. The Owner/Occupant then brought it to the team's attention that LEED certification - a Silver level - must be achieved in order to receive the A.R.R.A. grant, which was where the majority of the money was coming from to pay for the project. As a result, the design team had to go back and re-design parts of the facility and specify different equipment, fixtures, systems, etc. With the budget being fixed and $\mathrm{NO}$ additional funds available to upgrade to high-performance systems or equipment, seeking LEED certification was a huge challenge. If the project had desired to seek LEED certification from the on-set and design charrette(s) were conducted from the on-set, the project would have achieved a high LEED certification rating and would have provided more value.

28. None 
29. From the beginning, the owner's goal was for platinum certification which challenged the design team to perform at a higher level. Entire design and client team committed to working toward this common goal as, in the owner's eyes, failure to achieve was not an option.

30. Hard to get people to participate and spend more than 3 hours in a meeting.

31. There were some issues with the quality of the cost estimate for the project being insufficient to make the owner feel comfortable making decisions that had a significant impact on cost - equipment decisions, energy targets, etc. The energy issue was a significant issue as the client did not have a long term financial incentive to implement aggressive energy targets - in fact, the minimum was about the extent of the goal. Since the building was to be rented and renters would be responsible for utilities, the owner saw little reason to spend additional money on more efficient systems in units.

32. Design charrettes are an important part of the process of building development. They inform the players of the intent and goals of the project. Not all ideas are used from these sessions - but they contribute to the overall progress of the project.

33. Many times the conversations can get too detailed or focused on something that is irrelevant to the entire team.

34. They were not formal enough, we have since moved to a more formalized process with a longer duration.

35. No problems encountered

36. None - Always a great idea to have design charrettes to get everyone on the same page early in a project.

37. None 
38. No problems

Question 27: Do you have any suggestions for conducting successful design charrettes focused on producing LEED certified buildings?

1. Depending upon the knowledge base of the attendees, prepare ahead of time in order to provide strong leadership and guidance through the process of the charrette.

2. Set goals early. Establish clear communication and protocol Assemble the right team Get stakeholder buy in and document it Maintain commitment throughout process

3. Schedule earlier, include full design team.

4. As a group, set the project goals and limitations. Develop as a group the place holders and general locations for the project's components. Assign various smaller groups of professionals a specific portion of the project to examine in more detail, i.e. site plan, building footprint(s), spatial relationships, traffic flow, etc. Assemble groups of professionals with complementary talents and skills. Encourage out of the box thought processes. Then bring everyone together, let each individual group present their progress to the entire group for comment. Identify areas to be refined and work as one group or as several smaller groups to refine the basic macro ideas to a mid-micro level. Remember to engage everyone in the group and solicit everyone's opinion.

5. Start them early on in the project.

6. While establishing LEED objectives during a charrette is important, it is also important to not lose sight of other sustainability related goals that fall outside of LEED or the project's overall goals.

7. Understanding the clients expectations are huge.

8. Set project goals, get team buy-in, THEN look at the LEED credits. 
9. Establish clear goals in the beginning.

10. Always ask the question can we do this in a simpler way. Ask this question at every decision point to all team members, improved solutions can come from non experts.

11. Disagree that the goal is about LEED certification. The goal is improved social, economic and environmental sustainability. LEED is a byproduct.

12. Increased use of interactive media for efficient remote interactions (video conferencing (not just webinar/conference call).

13. The owner having defined project goals.

14. Start by assuming all credits are included in the program, and have the process be deductive rather than additive.

15. Think holistically and iteratively, and don't be afraid to have the wrong answer on the first iteration. "Make it, break it, fix it."

16. Fully educating the building owner on LEED and the LEED process to better align the owner's expectations before embarking on the design.

17. None - the process is budget driven.

18. Do one early to set goals do one during DD with engineers owners and CM to see how many goals can be achieved within the budget

19. No

20. Having a third party LEED charrette facilitator would have helped this project - mainly to provide expertise and experiences from projects with which we were not involved

21. The A/E teach should understand the cost impacts and/or feasibility of various LEED credits, so they know what can be achieved while still meeting the Owner's budget 
22. Most people are familiar with LEED, we focus more on the specific vs. broad generalities.

23. Earlier in the process the better, and having more than one charrette - at least at concept design, and then at schematic design.

24. The main thing is understanding the Owner's sustainable priorities for the facility.

25. Set the project goals BEFORE a pencil is put to paper, including sustainability goals. Use the OPR template to ask the important questions from the beginning...before "programming" the space and then setting a budget. The team CLEARLY needs to understand the Owner's goals EARLY in the design process and integrate those goals from the beginning. LEED is LEAST successful when it is added onto a project during the Construction Documentation phase. EARLY, EARLY, EARLY is key!!!

26. LEED discussions should be held independently from design charrettes and ideally, prior to design charrettes. Just like a design charrette can help a designer extract the desires and concerns of the owner, a charrette specifically geared towards environmental concerns will allow the design team to extract the owner's environmental concerns. From there, those concerns can be addressed and woven into the project's design.

27. Set the certification level early and get commitments from all participants to achieve or surpass the goal. Most often, by the time the project is three-quarters through construction, the original certification goal has been exceeded to the next level. Having the owner and builder participate is vital to review options and pricing of the options. 28. Understand the client/owner's LEED goals prior to the charrette. Not only the desired LEED certification level, but also the intent behind achieving LEED - jurisdiction 
mandate, market, long term maintenance cost reductions, financial incentives/rebate programs, etc.

29. The main point of charrettes are to bring out and explore as many issues as possible in a short time. When working on a LEED project a clear focus must be kept on the point goals and strategies to achieve them.

30. A good facilitator! The facilitator of the charrette is critical to keeping the conversations focused on the decisions that need to be made versus the detailed exploration that needs to occur at another time.

\section{INVITE EVERYONE YOU CAN!}

32. Our team focused on the high performance energy aspects throughout the process, but I do see value in charrettes that surround the idea of sustainable design. Getting stakeholders together is always beneficial to the project, especially when they come from areas outside of the design and construction field. The [project] repurposed a mid-century residence hall into new offices for the campus Architects, Engineers and Planners, so the process was streamlined by not having that learning curve.

33. Schedule them early and often with larger groups, and narrow down to smaller, more item specific groups once to fine-tune design solutions.

34. Start with the charrette before any design work begins

35. LEED should never be the driver of the design. Smart architectural design is sustainable and should be the priority. Once an architectural concept has been established, then look at LEED options. 


\section{Appendix M: Institutional Review Board Approval Letter}

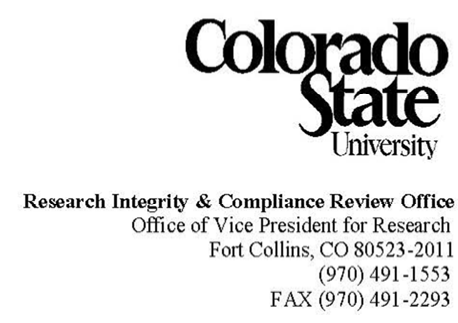

DATE: $\quad$ September 10, 2012

TO: $\quad$ Caroline Clevenger, Construction Management

Michael Knox, Construction Management

FROM: Janell Barker, IRB Coordinator

Research Integrity \& Compliance Review Office

TITLE: Investigating the Impact of Charrette Characteristics on Achieved LEED

Certification

IRB ID: $\quad 153-12 \mathrm{H} \quad$ Review Date: September 10, 2012

The Institutional Review Board (IRB) Coordinator has reviewed the modification of this project:

* to offer a chance at a drawing for participating in the research using the revised recruitment/consent with this information; names will be separate from the survey data, maintaining confidentiality.

and has declared the study remains exempt from the requirements of the human subject protections regulations as described in 45 CFR 46.101 (b)(2). The IRB determination of exemption means that:

- You do not need to submit an application for annual continuing review.

- You must carry out the research as proposed in the IRB application, including obtaining and documenting (signed) informed consent if stated in your application or if required by the IRB.

- Any modification of this research should be submitted to the IRB through an email to the IRB Coordinator, prior to making any changes, to determine if the project still meets the Federal criteria for exemption. If it is determined that exemption is no longer warranted, then an IRB proposal will need to be submitted and approved before proceeding with data collection.

- Please notify the IRB if any problems or complaints of the research occur.

Please note that you must submit all research involving human participants for review by the IRB. Only the IRB may make the determination of exemption, even if you conduct a similar study in the future. 


\section{Appendix N: E-Survey Instrument Permission}

$3 / 7 / 13$

Gmal - Suney for Thesis Permission

Michaei Knox sfortknox0024@gmail.coin?

\section{Survey for Thesis Permission}

KatWagenschutz<kwagenschutz@usgbc.org>

Wed, Mar 13, 2013 at 9:02 AM

To: Michael Knox <fortknox0024@gmail.com>

Michael,

This e-mail is to confirm that you have my permission to use the survey instrument designed for my thesis research. The questions, format, and any other feature of the survey may be replicated for the purposes of completing your thesis research.

Sincerely,

Katherine Wagenschutz

Technical Solutions

kwagenschutz@USGBC.org

US Green Building Council

2101 L Street NW, Suite 650, Washington DC 20037

USGBC. org | Main 202.828.7422 | Direct 202.251.6088 